\title{
EL GOBIERNO DEL CABALLO MONTADO EN LA ANTIGÜEDAD CLÁSICA CON ESPECIAL REFERENCIA AL CASO DE IBERIA. BOCADOS, ESPUELAS Y LA CUESTIÓN DE LA SILLA DE MONTAR, ESTRIBOS Y HERRADURAS.
}

\author{
POR
}

FERNANDO QUESADA SANZ

\section{RESUMEN - ABSTRACT}

Se analizan los elementos de control del caballo montado en la Antigüedad: bocados, espuelas, silla y estribos, y se hace referencia al problema de las herraduras, todo ello con especial referencia al caso de la antigua Iberia.

We examine the different elements of the horse's tack in Antiquity: bits, spurs, saddle, stirrups and the problem of horseshoes, with special reference to the case of Iberia.

\section{PALABRAS CLAVE - KEY WORDS}

Caballo. Edad del Hierro. Grecia. Roma. Iberia. Bocado. Espuelas. Silla de montar. Ephippion. Estribos. Herraduras.

Horse. Iron Age. Greece. Rome. Iberia. Horse bit. Spurs. Saddle. Ephippion. Stirrups. Horsehoes.

La importancia social y militar del caballo en la Antigüedad clásica ha sido reconocida desde hace mucho y ha sido objeto de una amplísma bibliografía. El efecto que causa un jinete, capaz de mirar a sus vecinos desde el aura de superioridad que confiere la altura de su montura, fue en la Antigüedad hecho social reconocido, heredado desde la época de los prestigiosos carros de la Edad del Bronce ${ }^{1}$.

La monta no es sólo una una cuestión de habilidad y experiencia, sino que la psicología y la sensibilidad del jinete y la compenetración con su montura son esenciales. Pero pese a que caballo sea por lo general dócil al mando de un jinete razonablemente experimentado, tiene un cerebro y voluntad independientes y - especialmente en el caso de la monta militar que implica demandas bruscas y exige, por cuestión de vida o muerte, respuestas eficaces e instantáneas - a menudo es necesario el empleo de elementos mecánicos severos que facilitan la monta y el control del animal y la estabilidad del jinete. Éstos pertenecen fundamentalmente a cuatro grupos: en primer lugar los aplicados directamente sobre la boca y cabeza del caballo, sobre todo los bocados y además, diversos tipos de cabezada metálica, serretas y frenteras. En segundo lugar, estímulos puntuales empuñados por el jinete, como espuelas y fustas; en tercero, elementos que mejoran la estabilidad y seguridad del jinete, silla y estri-

\footnotetext{
1 Ver Budiansky (1997:59 ss.); in extenso, especialmente Piggott (1992), particularmente el Capítulo III para los jinetes.
} 
bos; y por último, y en una categoría diferente, elementos que protegen los cascos del caballo y le dan un apoyo mas seguro en determinados terrenos, hiposandalias y herraduras. A todos estos elementos, con diverso grado de detalle, y especial énfasis en la Edad del Hierro de la Península Ibérica, nos referiremos en las páginas siguientes.

Los movimientos instintivos y los patrones de acción de los caballos han permanecido idénticos desde proceso de domesticación, muy reciente en términos zoológicos (Hyland, 2003:49). También los mecanismos de control del caballo montado (no entraremos aquí en el complejo tema de los arneses y tiros) han permanecido básicamente los mismos desde la Edad del Bronce hasta la actualidad, incluyendo tanto las sutiles guías ejercidas por la posición y presión del cuerpo del jinete como las más radicales indicaciones de la fusta, la espuela y el bocado. En particular los elementos mecánicos mediante los que el jinete puede imponer rápida y decisivamente su voluntad al caballo, en especial los diferentes tipos de bocado, jáquima y espuela, e incluso la silla de montar con borrenes y arzón, estaban ya presentes en los primeros siglos del Imperio Romano. Los estribos se introdujeron en el mundo mediterráneo y en Europa Occidental hacia el s. VII d.C. Las aportaciones al control desde aquella época han sido de detalle, y no modificaciones sustanciales (Edwards 1994:17).

\section{ELEMENTOS DE CONTROL EN LA CABEZADA. EL BOCADO.}

\section{Jáquimas, bozales y bocados.}

Ya desde los primeros tiempos de la domesticación del caballo, ${ }^{2}$ el mundo antiguo se caracterizó por un uso muy severo de los elementos de control, mucho más duro de lo que hoy se consideraría aceptable (Hyland, 2003:50-54). El control por el miedo y el dolor, y en especial por la presión ejercida en el diastema o barras de la mandibula inferior del caballo, la palanca sobre la comisura de la boca y luego sobre el paladar y la barbilla, se ejercían hasta un punto que hoy se consideraría inaceptable, lo mismo que las piezas de la embocadura destinadas, mediante púas (achine, erizo) o discos relativamente afilados (Fig. 1), a impedir que el caballo llegara a 'morder' el bocado (Hyland, 1993:52-53). Otras regiones, por ejemplo el mundo parto-sasánida del Próximo Oriente empleaban igualmente bocados muy severos (Azzaroli 1985:93). Como ha indicado S. Budiansky, el uso de métodos algo extremos encaja con la concepción que los antiguos guerreros tenían de sí mismos, de la naturaleza de la batalla, y de la de sus fieros sementales, que a menudo quedaban sin castrar (Budiansky, 1997:57).

La caballería ligera númida norteafricana guiaba sus caballos no sólo sin bocado, sino incluso sin cabezada, empleando únicamente una cuerda atada al cuello del caballo (lo que asombraba a los romanos, prestos al principio a despreciarles Livio 35, 11, 8; relieves de la Columna Trajana, Fig. 2; ver Anderson 1961:34 y 40), pero este sistema, que implica un delicado control de la montura con movimientos del cuerpo y presión de las piernas, es una rareza en el mundo mediterráneo, y parte de la base de que el jinete no puede llevar mucha protección corporal que aumente su peso y eleve su centro de gravedad (Hyland, 1990:174): es por tanto típico de caballería ligera. Por otro lado, diferentes escuelas modernas que enseñan a montar con un mínimo de ayudas mecánicas testifican la eficacia que se puede conseguir (Gaebel 2002:12 con ejemplos). Jenofonte, en su tratado Sobre la equitación, manifiesta a menudo conocer la importancia del trabajo psicológico con el caballo, y recomienda en varias ocasiones la moderación en el uso de los controles: «debe evitarse tirar de su boca

\footnotetext{
${ }^{2}$ Sobre la domesticacion del caballo ver en último lugar, resumiendo la evidencia, Levine (2004). Como se indica, a lo largo del tiempo las fechas propuestas oscilan entre el Neolítico y el Bronce Medio, en las estepas euroasiáticas o en Europa Occidental, en uno o en varios lugares de modo más o menos simultáneo, y como alimento, para la monta o para la tracción. Todas las posibilidades, pues, han sido propuestas en un momento u otro y la cuestión dista de estar cerrada.
} 


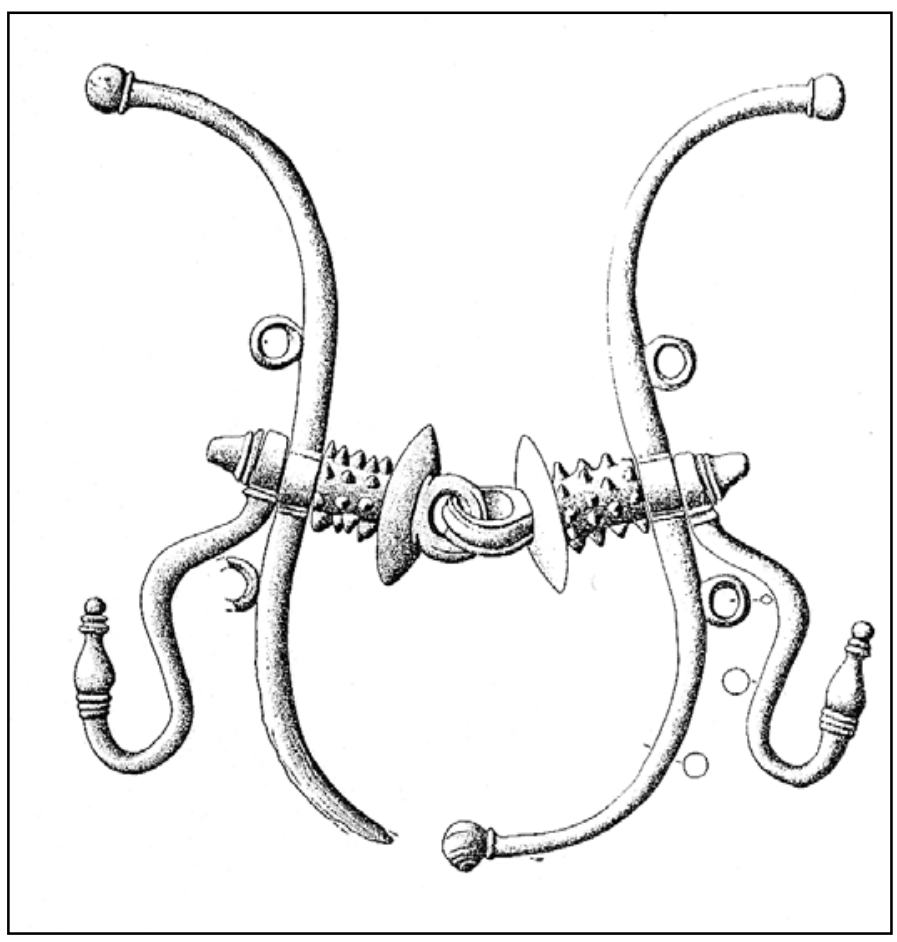

Fig. 1. Severo bocado griego del tipo VIII de Donder (1980, $\mathrm{n}^{\mathrm{o}}$ 79). Posiblemente s. IV a.C. Procedencia desconocida.

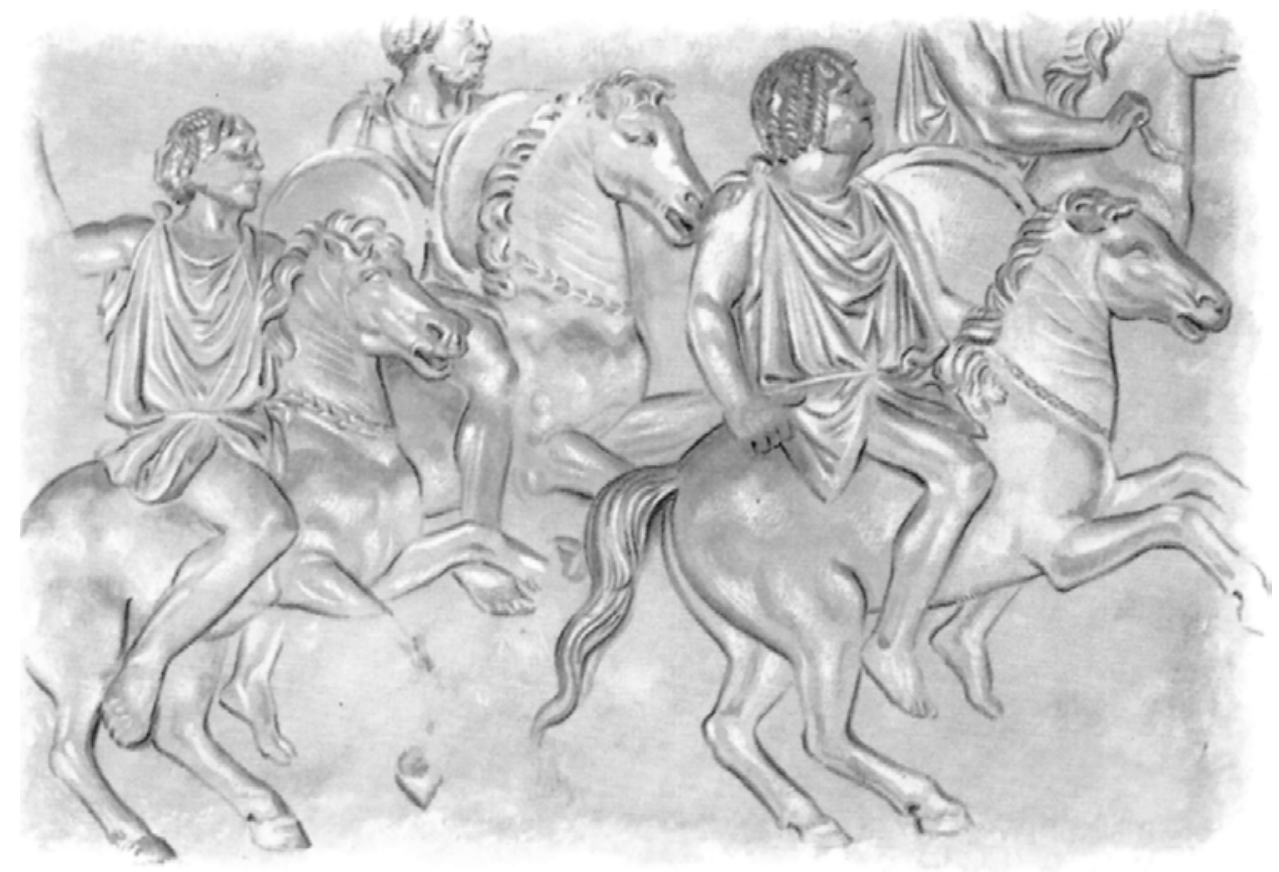

Fig. 2. Jinete ligero númida montando sin bocado. Relive de la columna trajana (según P. Connolly 1981). 
con el freno, picarlo con la espuela y arrearlo con el látigo, cosas que hacen muchos creyendo que resulta vistoso; el resultado es todo lo contrario de lo que ellos pretenden... (10.1); pues lo que el caballo hace obligado...no lo comprende mejor ni es más bello que si uno dirigiera a un bailarín al son del látigo o del aguijón. Realmente, quien soporte tal trato, sea hombre o caballo, más que hacer algo con arte lo ejecutará torpemente...» (11.6) (trad.Orlando Guntiñas, BCG). Pese a ello, su propia descripción de los dos bocados que debe poseer un jinete $(10,6-7)$, extremadamente severos, y el tenor de su texto, demuestra que la paciencia y la empatía con el caballo no eran técnicas ni mucho menos generalizadas en el mundo griego antiguo (Hyland, 2003:54).

El Mediterráneo clásico conocía la jáquima y las cabezadas y bozales sin bocado, empleadas sobre todo en trabajo de establo (Anderson 1961:42 ss.; Jenofonte, De la Equitación 5,3 ), así como la cabezada rígida metálica, una forma de serretón o psalion ('tijera') que se combinaba con el bocado en caballos que tienden a abrir mucho la boca (Fig. 3) (Anderson, 1961:60, Lám. 37; Hyland, 1990:140 ss., especialmente Lám. 16 e ilustración de portada; también 1993:63-64; 2003:58; especialmente Taylor 1975; Schwinden 1987).

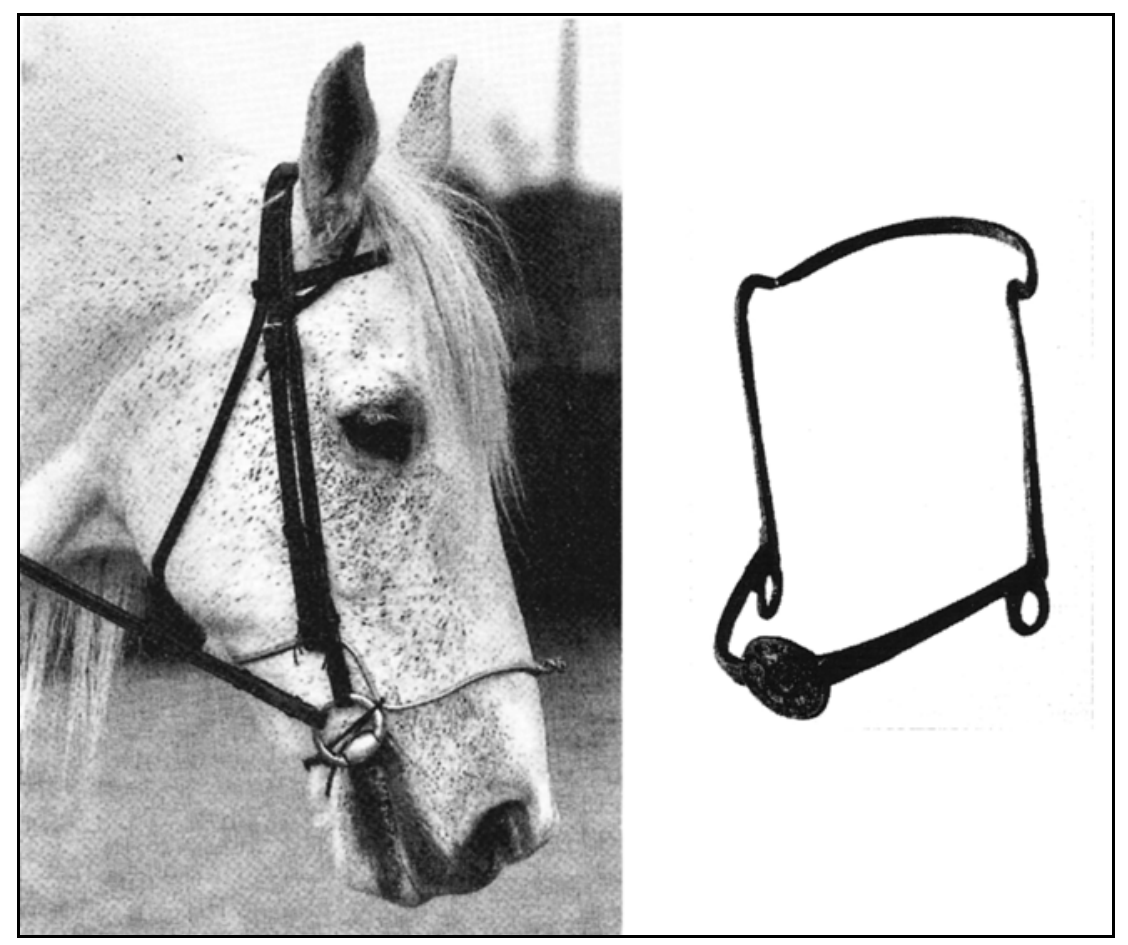

Fig. 3. Psalion o tijera. Original romano de Newstead, s. II a.C. (de Anderson 1961, Lám. 37) y reproducción en combinación con un bocado de filete (de Hyland, 1990:Lám. 16).

Igualmente se empleaban bozales metálicos calados para impedir que el caballo mordiera y mantener su boca cerrada (Anderson, 1961:43, Lám. 36a; Hyland, 2003:58; la última autora considera que estos bozales de bronce se podían usar en combinación con un filete) (Fig. 4). Algunos de estos bozales se han encontrado en la Penísnula ibérica en contextos prerromanos como La Pedrera de Vallfogona (Garcés 2002:198-199), y otros en contextos que posiblemente sean ya romanos. 


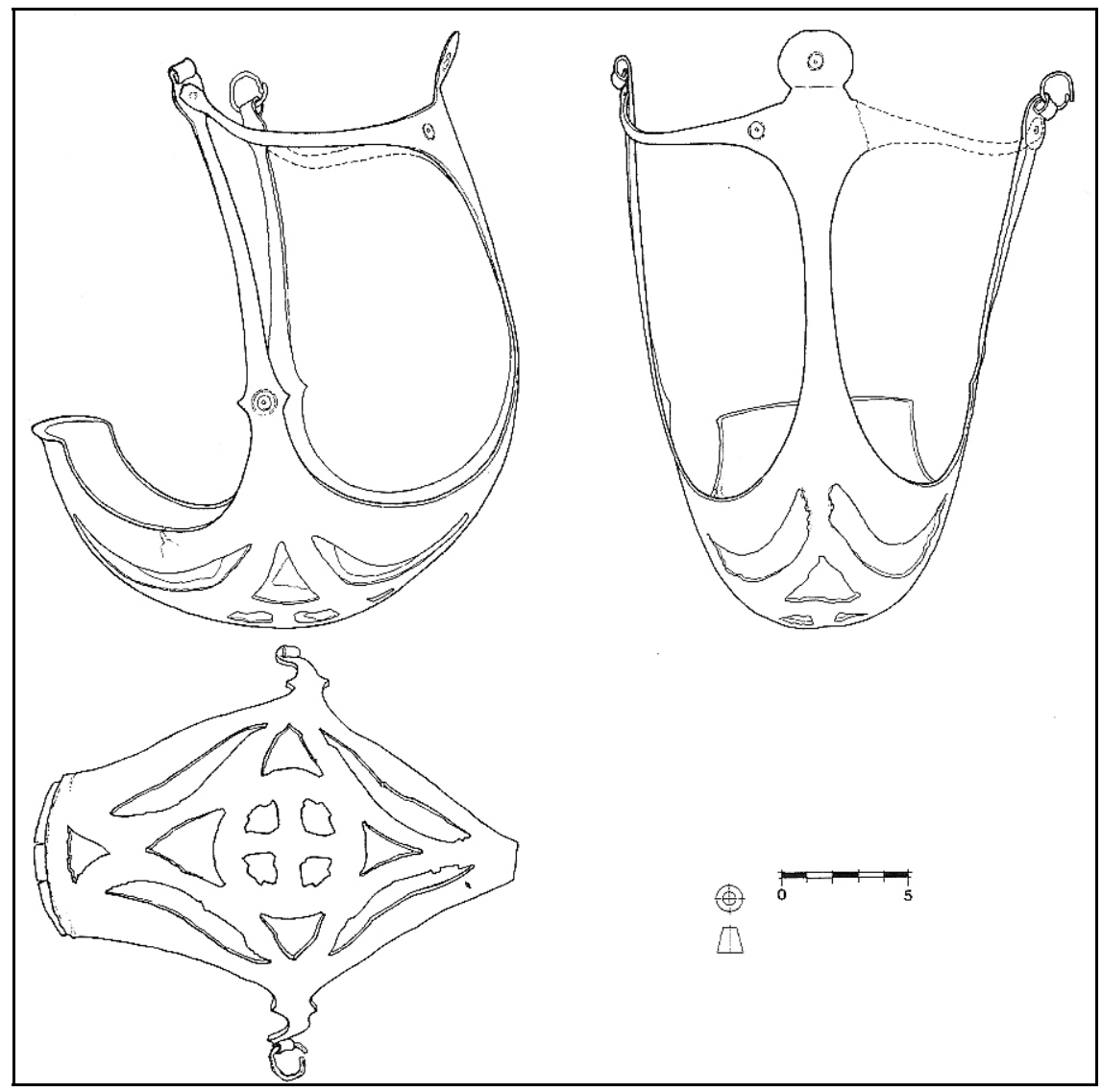

Fig. 4. Bozal metálico prerromano procedente de La Pedrera de Vallfogona de Balaguer (Lérida) (según Garcés 2002).

Pero el control del caballo montado se efectuaba sobre todo mediante el empleo de dos tipos de bocado: el filete articulado (Fig. 5) y el bocado de freno con barbada rígida o de cadena (curb), y casi siempre con desveno (port), a menudo muy alto (Fig. 6). El mundo griego - y el ibérico prerromano- sólo empleó el primer tipo (Fig. 7), mientras que un tipo de bocado de freno con desveno y barbada fue introducido por los celtas y empleado luego por los romanos y por los celtíberos ${ }^{3}$ (sobre los dos tipos, Anderson 1961:50-52; Hyland, 1990:136 ss.; 1993:54; matices no siempre fáciles de seguir en Hyland, 2003:56 ss.) ${ }^{4}$. (Figs. 8 y 9) Otros autores sin embargo consideran que el bocado de freno en sentido moderno no apareció hasta el Renacimiento, y que los bocados así llamados en la Antigüedad tenían un funcionamiento ligeramente diferente (Azzaroli 1985:120 ss., siguiendo a Lefèbvre des Noëttes). La distinción nos parece en exceso fina, porque el principio es el mismo: utilizar una acción de palanca y una combinación de acción sobre la barbilla, sobre el diastema y a veces sobre el paladar (Hyland, 1993:54-55; Anderson 1961).

3 Sobre bocado de freno celtibérico con desveno y acción de palanca ver el tipo 5 de Argente, Díaz, Bescós (2000:41-42) que a nuestro juicio es un bocado de freno o curb como opinaba en su momento el marqués de Cerralbo, y contra la opinión de los autores citados ( $v$. infra).

4 Sobre el equipo moderno del caballo puede consultarse en español Britton (1997);Edwards (1994). En inglés, ver también Summerhay (1993) y Britton (1995). Se advertirá que hay numerosas inconsistencias en la terminología, sobre todo en las traducciones, que pueden llegar a ser desconcertantes para el no experto. 


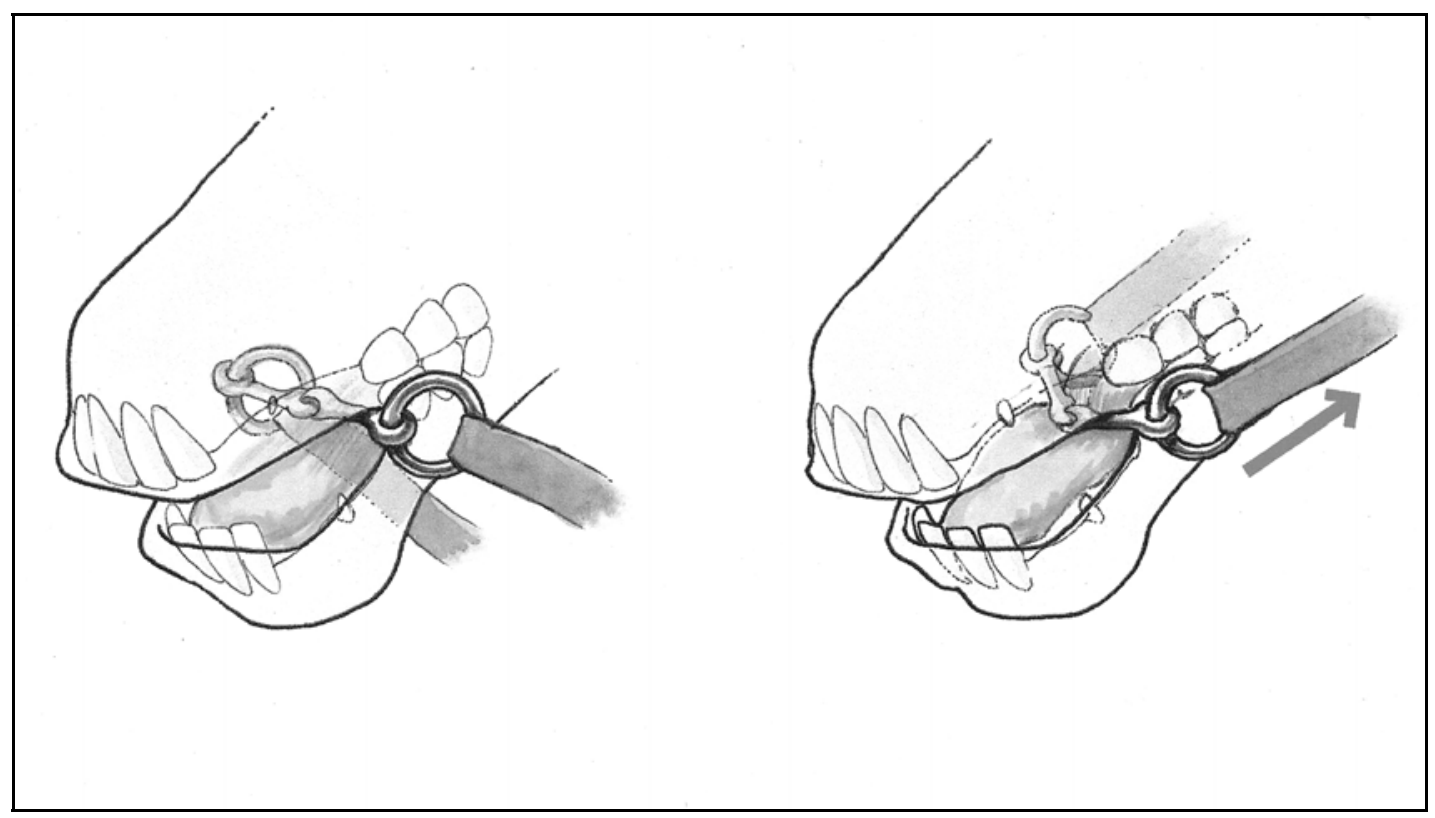

Fig. 5. Principio de acción del bocado de filete articulado (según Quesada y Fernández del Castillo).

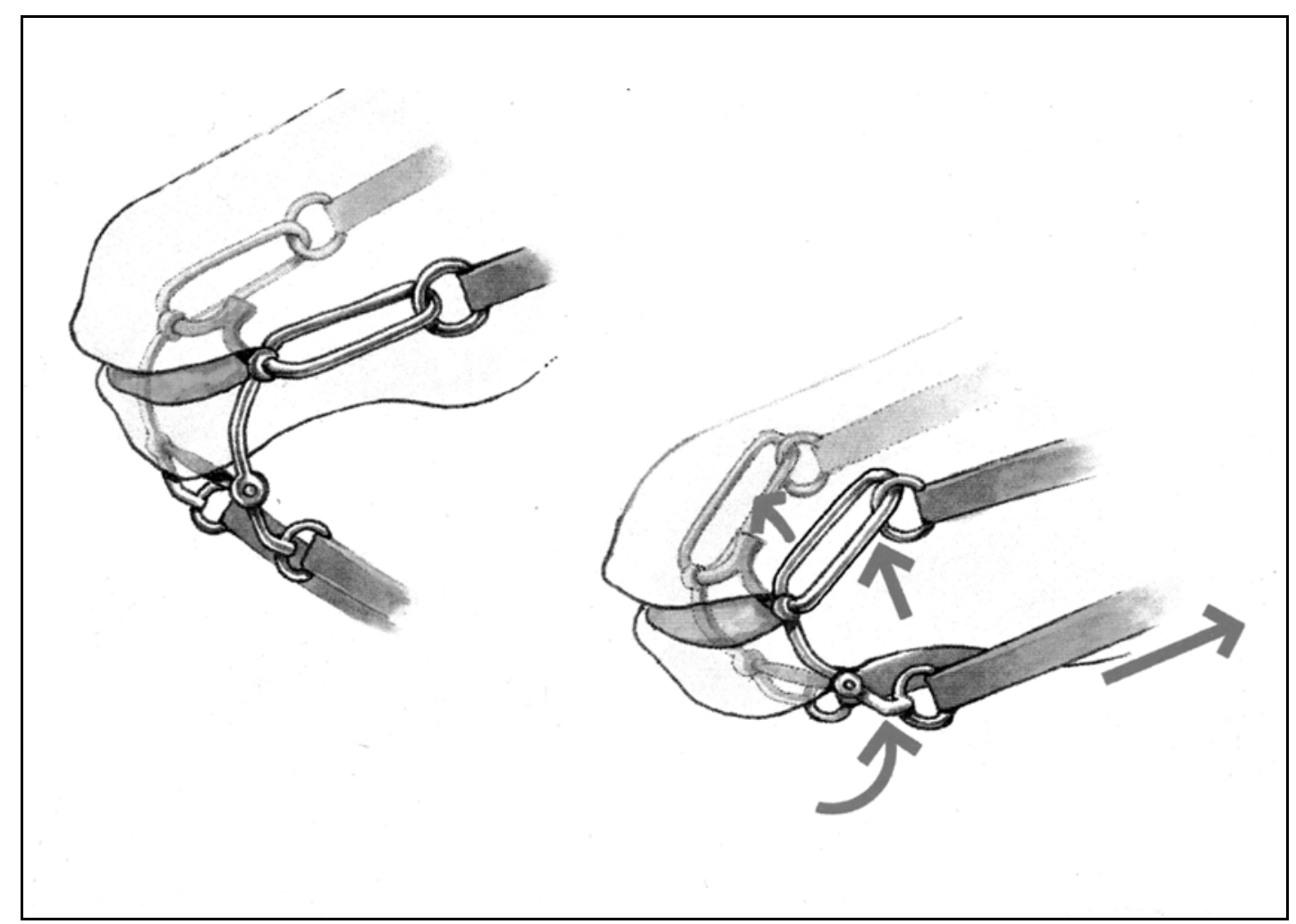

Fig. 6. Principìo de acción del bocado de barbada con desveno (según Quesada y Fernández del Castillo). 


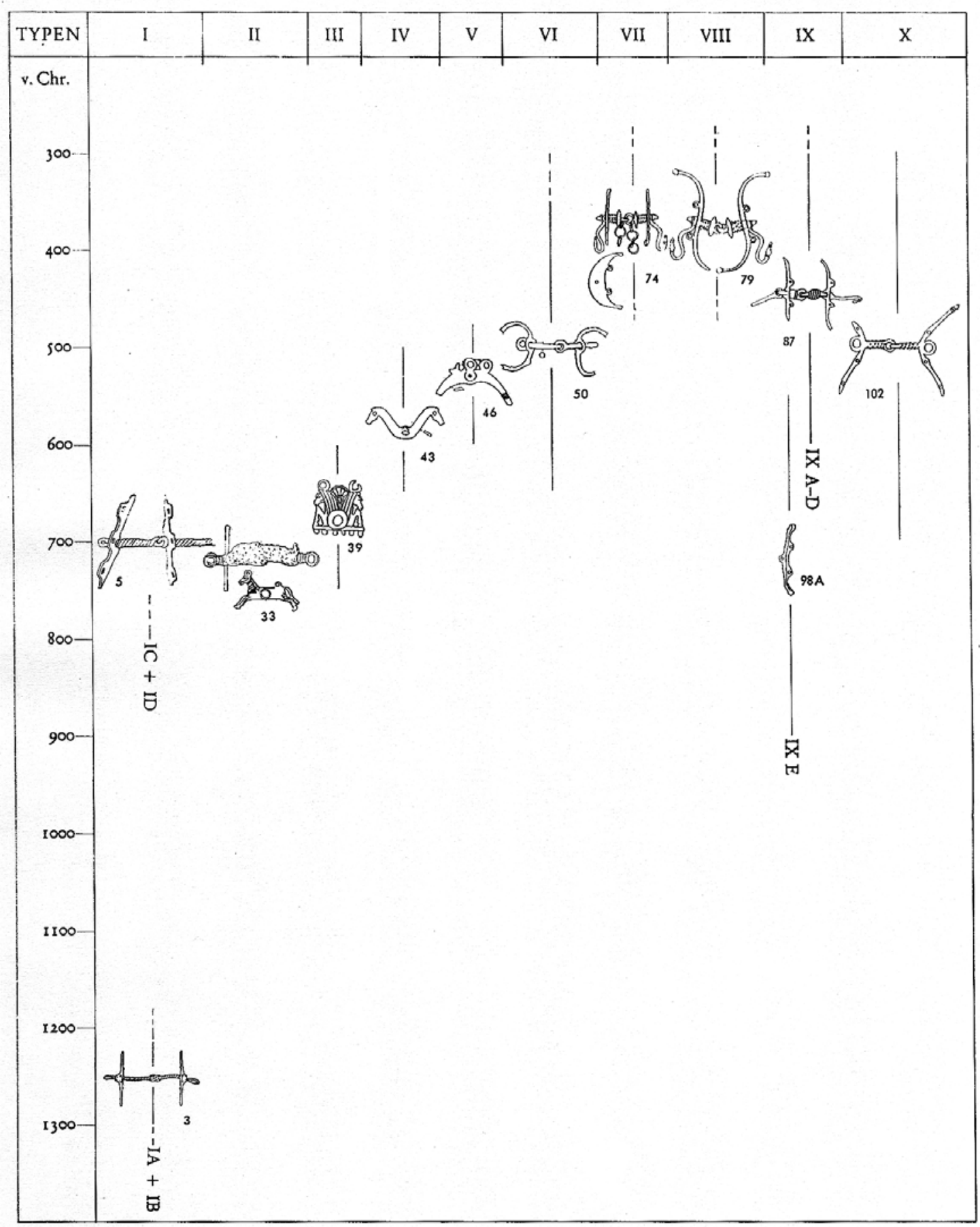

Fig. 7. Tipología de bocados griegos de caballo -del tipo de filete (según Donder 1980). 


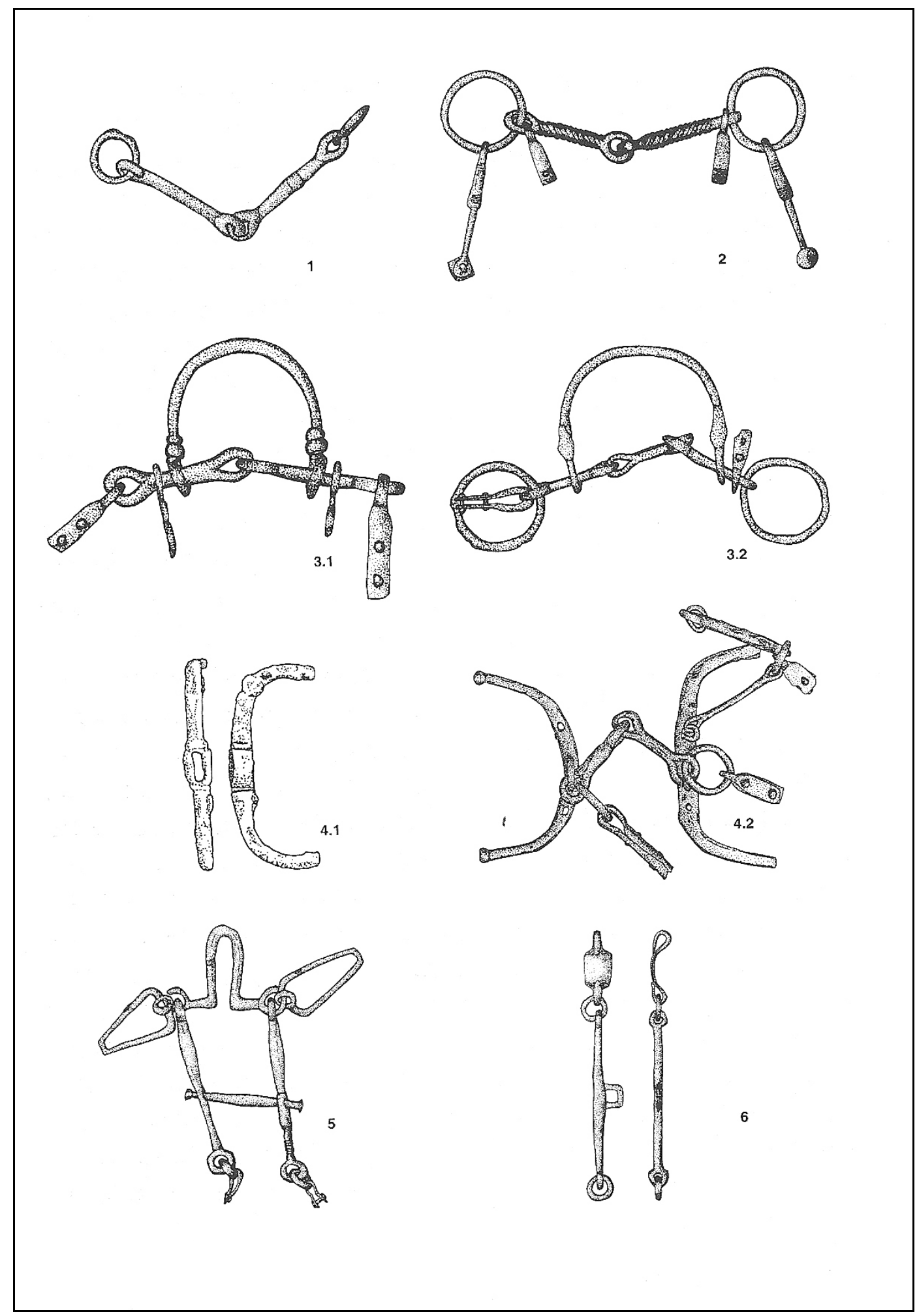

Fig. 8. Tipos de bocados de caballo en la necrópolis celtibérica de Carratiermes (Soria) (según Argente, Díaz, Bescós 2000). 


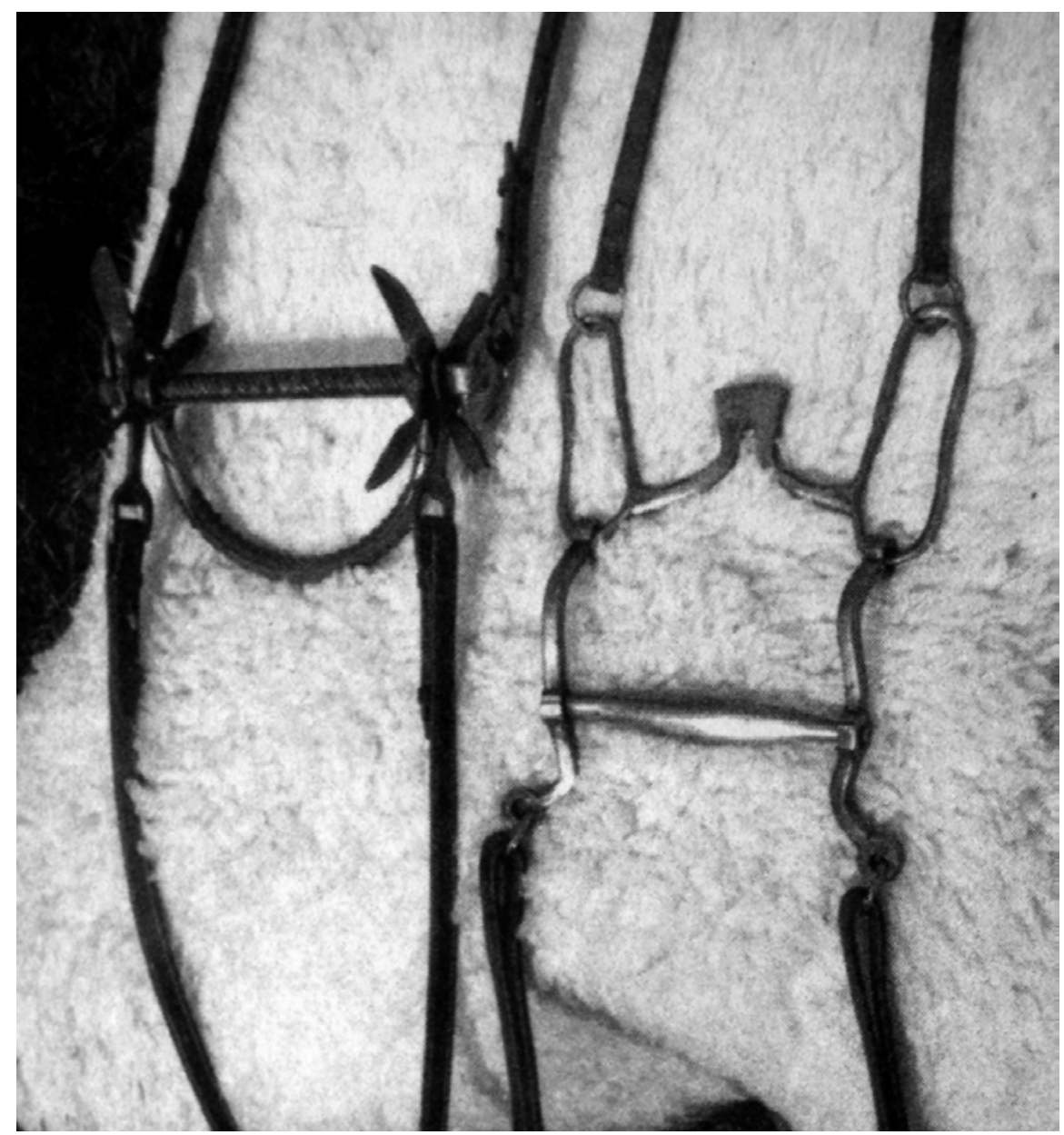

Fig. 9. Bocados romanos de Newstead (según A. Hyland 1993:57). S. II d.C. Obsérvese la orientación del 'serretón' del bocado de filete como barbada. La autora considera el segundo un curb bit o bocado de freno verdadero.

\section{Los primeros bocados de la Edad del Hierro en Iberia (siglos VII-V a.C.)}

Los primeros bocados de la Edad del Hierro pertenecen en Iberia a tres contextos diferentes. Por un lado, contamos con algunos restos muy dañados de bocados de filete rígido en hierro procedentes de contextos de la Primera Edad del Hierro en el ámbito catalán. El mejor conservado es el del poblado de La Ferradura (Tarragona), un bocado de filete rígido con cañón de $13 \mathrm{~cm}$. y dos grandes anillas para el enganche de las riendas, que actuarían también a modo de camas (Fig. 10) (Maluquer 1987:Fig. 11). Los trabajos recientes fechan dicho poblado en torno a 625-550 a.C. (Gracia, Munilla 1993:216). Quizá uno de los objetos de hierro más antiguos de Cataluña es el posible cañón de embocadura hallado en UE 5348 de la Fase IIb de la estatigrafía de Sant Martí d'Empúries (Aquilué et al. 1999:Fig. 187.17 y p. 179), fechado en 625/600-580 a.C. (Aquilué et al. 1999:471). Sin embargo, su longitud (14 cm. ) parece excesiva para tratarse - como proponen los excavadores - de un cañón de un filete articulado, por lo que, o se trata de una embocadura rígida completa o la pieza corresponde a otro obje- 
to. Sin embargo, a partir del dibujo publicado podría deducirse que la embocadura real mediría sólo en torno a $10 \mathrm{~cm}$., lo que sí permitiría hablar de un gran bocado articulado de unos $18-20 \mathrm{~cm}$.

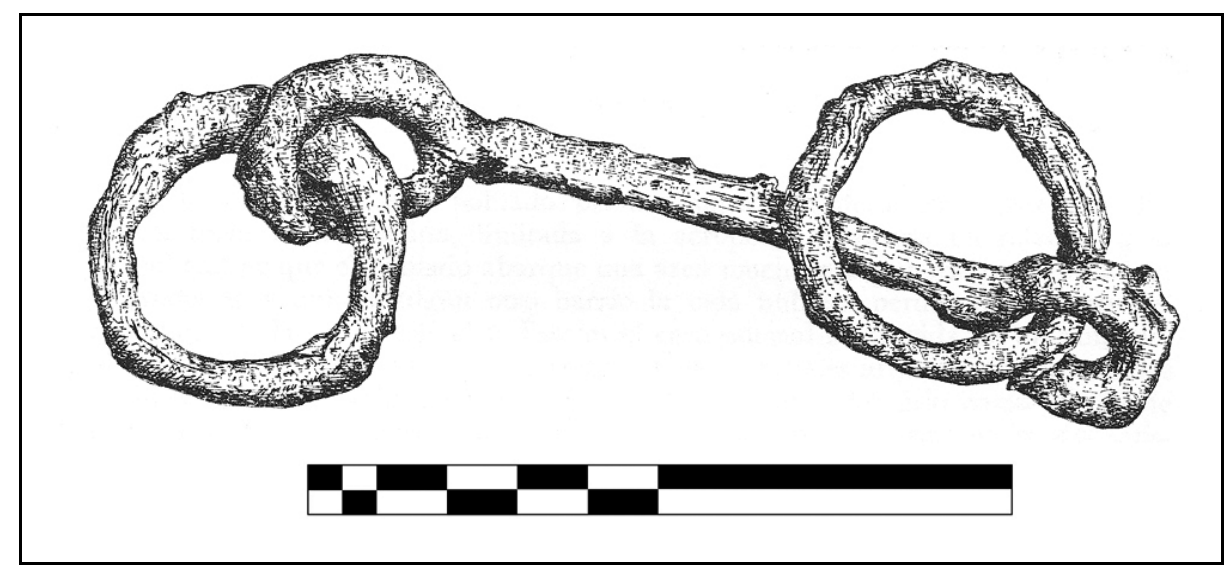

Fig. 10. Bocado de filete de embocadura rígida en hierro del poblado de La Ferradura (Ulldecona, Tarragona). C. 650-600 a.C. Según Maluguer (1987).

En general las dimensiones de los bocados peninsulares de la Edad del Hierro son muy grandes - entre 12 y casi $20 \mathrm{~cm}$. - en comparación con los bocados modernos que oscilan entre los 10 y los $15 \mathrm{~cm}$. de ancho total de la embocadura (Hyland 1990:139). Sobre el tamaño de los bocados modernos en comparación con los antiguos, y en particular sobre la longitud de los cañones de la embocadura, ver Hyland (1990:139-140), Balkwill (1973) y Jiménez Avila (2002:229). Aunque los bocados peninsulares de la Edad del Hierro presentan embocaduras consistentemente grandes, hay paralelos itálicos y chipriotas que se mueven en la misma magnitud; esto quizá implica una mayor acción de presión sobre el lateral de la boca del caballo al tirar de las riendas y una acción más severa que en la actualidad, consistente con lo que sabemos del gobierno del caballo en la antigüedad.

Quizá corresponda también a un bocado del tipo del de la Ferradura la anilla de hierro hallada en la U.H. 67 de La Moleta del Remei (630-550 a.C.) (Gracia, Munilla, García 2000:65). Algunos otras anillas fragmentarias de hierro procedentes de contextos de principios del s. VI a.C., como Ampurias, están en un estado que imposibilita su identificación positiva como bocados de caballo.

Junto con estos bocados de tipología extremadamente sencilla y probable origen trasnpirenaico (Balkwill 1973), en la mitad meridional de la Península contamos con otra serie que podríamos considerar como 'Orientalizante', fechable en los siglos VII-VI a.C. y que se debe separar de otra serie algo posterior (coincidimos en ello con Jiménez Avila 2002:225 ss. a quien se debe el más completo estudio de estos bocados).

De la primera serie orientalizante, poco frecuente, probablemente el más antiguo sea el par de bocados hallado en la Sep. 17 de la necrópolis de La Joya (Huelva) (Fig. 11), en bronce y latón para las placas laterales más visibles. Se trata de la que probablemente sea la tumba más rica de la necrópolis (Quesada 1998a:Fig. 12), contando entre sus restos con el bien conocido carro de tipología probablemente chipriota, y fechable según estudios detallados entre 700-650 a.C. (Fernández Jurado, 1988-89:226), por tanto significativamente antes que los bocados de hierro del nordeste. 


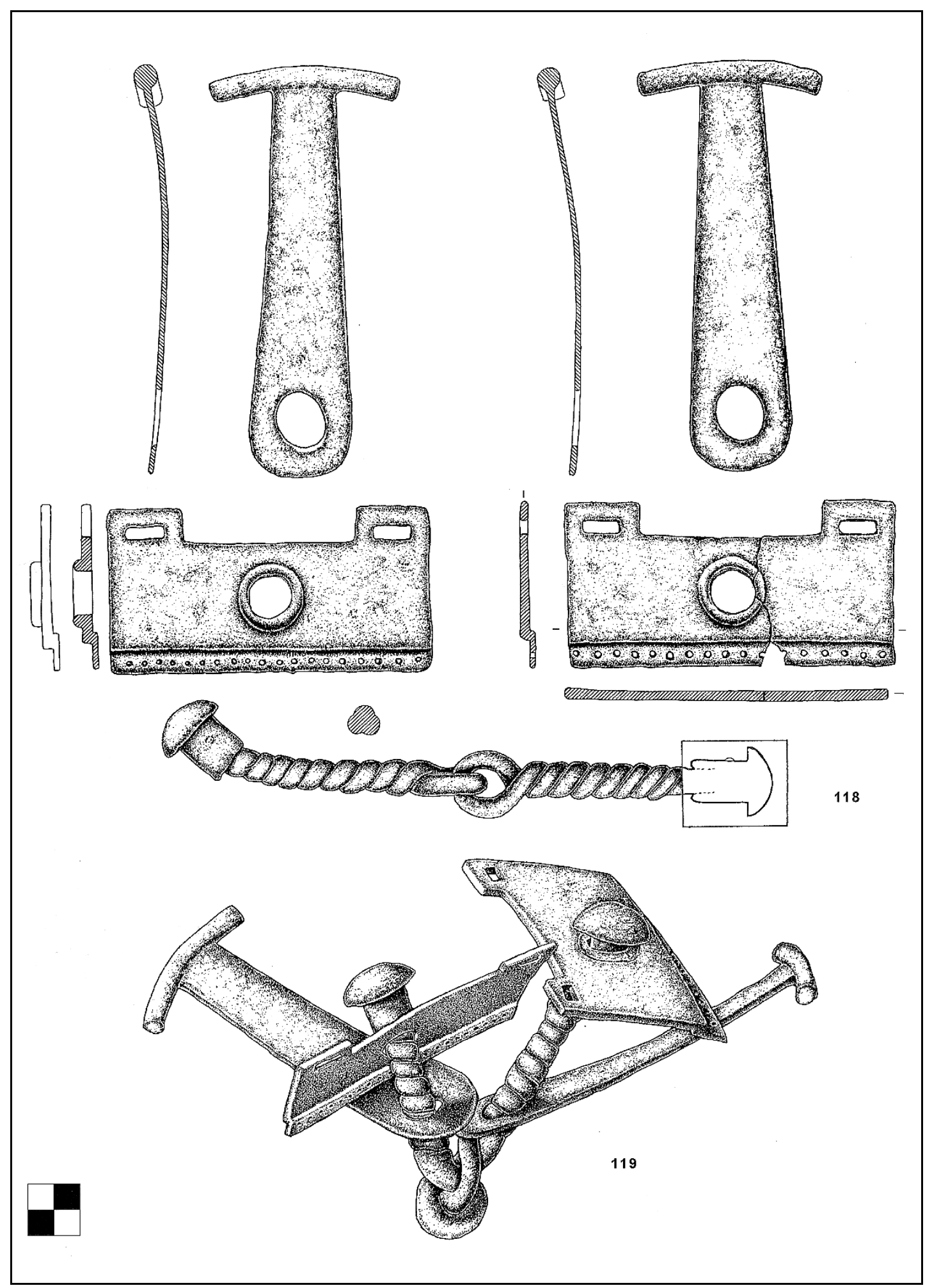

Fig. 11. Bocados de bronce y latón de la Sep. 17 de La Joya, c. 700-650 a.C. Según Jiménez Avila (2002) 
Dado que aparece un par de bocados, cabe pensar que estarian destinados al tiro del vehículo funerario depositado en la misma tumba. Junto a los bocados (Garrido, Orta 1978:84) aparecieron además cuatro piezas de bronce (Fig. 12) que tienen paralelos cercanos en una pieza similar de Cancho Roano en hierro (Blech 2003:165 y Fig. 5) y que parecen predecesores de un tipo similar pero con las barras dobladas en forma de falsas 'camas' curvas que se halla en numerosos yacimientos de la Segunda Edad del Hierro, tanto meseteños (Carratiermes, ver Fig. 8, tipo 4.1; Las Cogotas Sep. 383, La Osera Sep. 393; Altillo de Cerropozo Sep. 16, etc.) como ibéricos (por ejemplo Cigarralejo, Sep. 103) ${ }^{5}$; estas piezas suelen considerarse camas de bocado aunque nunca aparecen con su embocadura. Si esto fuera cierto cierto, y puesto que en la Sep. 17 de la Joya aparecen también cuatro pasarriendas, podríamos pensar que el vehículo funerario fue una cuádriga (bien documentada en la necrópolis de Salamina de Chipre, Crouwel 2002) con los dos caballos interiores llevando bocados más sencillos que los dos exteriores ${ }^{6}$.

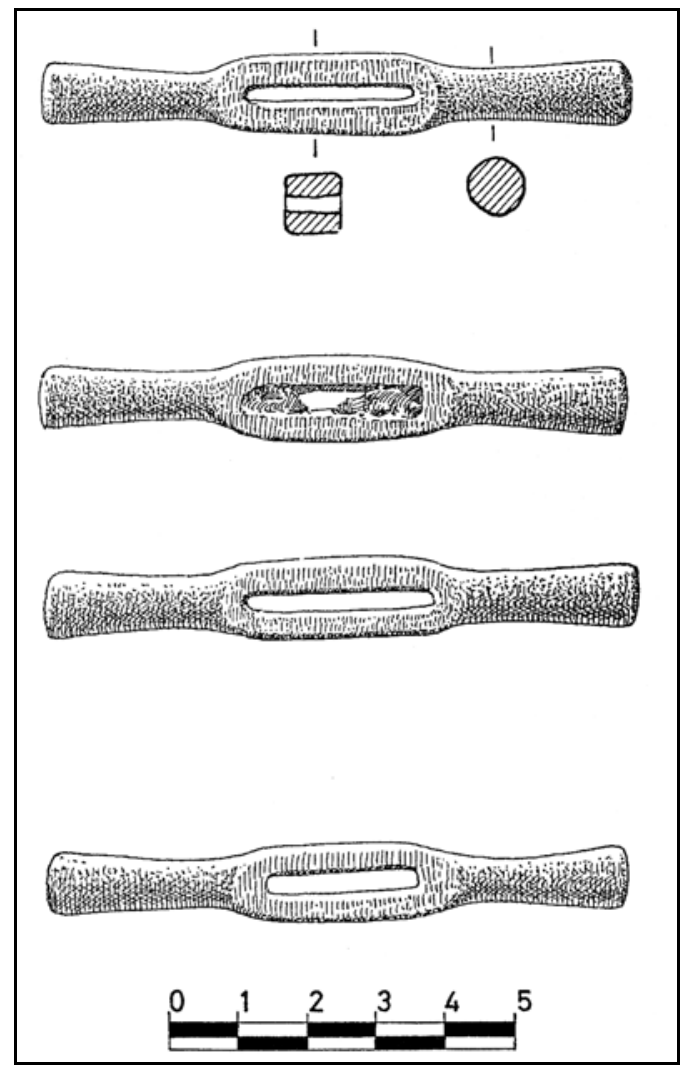

Fig. 12. Posibles elementos de arreo en bronce de la Sep. 17 de La Joya. Según Garrido y Orta (1978).

5 Blech (2003:165; Argente, Diaz, Bescos, 2000:74-75) con las oportunas referencias bibliográficas. Compartimos con los investigadores de Carratiermes nuestra extrañeza sobre estas piezas que, aunque parecen asociadas a los caballos-caso de La Joya- plantean problemas por la colocación del supuesto orificio para pasar la -siempre inexistenteembocadura, ya que el orificio es paralelo en lugar de perpendicular al plano definido por la cama, por lo que colocado en la boca del caballo las camas, cuando son curvas, sobresaldrían en una posición antinatural. Conviene realizar un estudio específico de este tipo.

6 Hay indicios de que un pasarriendas corresponde normalmente a las dos riendas de un caballo (e.g. Littauer, Crouwel 1979; Figs. 55, 61, 82) aunque esto no es siempre así (Crouwel 2002:161 n. 85), y se han propuesto reconstrucciones de yugos con dos gamellas y cuatro pasarriendas, uno por rienda, no por caballo (Jiménez Avila, 2002:222, Fig. 166), lo que exigiría una discusión que aquí no podemos plantear. 
Los dos bocados seguros son tipológicamente muy peculiares (Garrido, Orta 1978:87; Jiménez Avila 2002:226 ss.; Blech 2003:167-168), con filete de cañones articulados sogueados y camas rectangulares con numerosas perforaciones pequeñas; el conjunto permite al menos tres opciones de reconstrucción (Fig. 13) (Garrido, Orta, 1978:Fig. 53; Jiménez Avila 2002:Fig. 172) de las que sin duda la más plausible es la de Jiménez Avila (Fig. 13c). Aunque el conjunto del carro de La Joya tiene fuertes connotaciones chipriotas -aunque tampoco faltan paralelos con elementos etruscos, cf. Jiménez Avila 2002:224-225; Emiliozzi 1997 passim), este tipo de bocado no es conocido, hasta lo que sabemos, en Chipre, donde las camas de los bocados suelen ser estrechas y alargadas (Crouwel 2002:159-160 y Pl. 34) y el tipo tampoco aparece en el repertorio de Donder para Grecia y Chipre (Donder 1980) ni en el de von Hase (1969) para Italia.

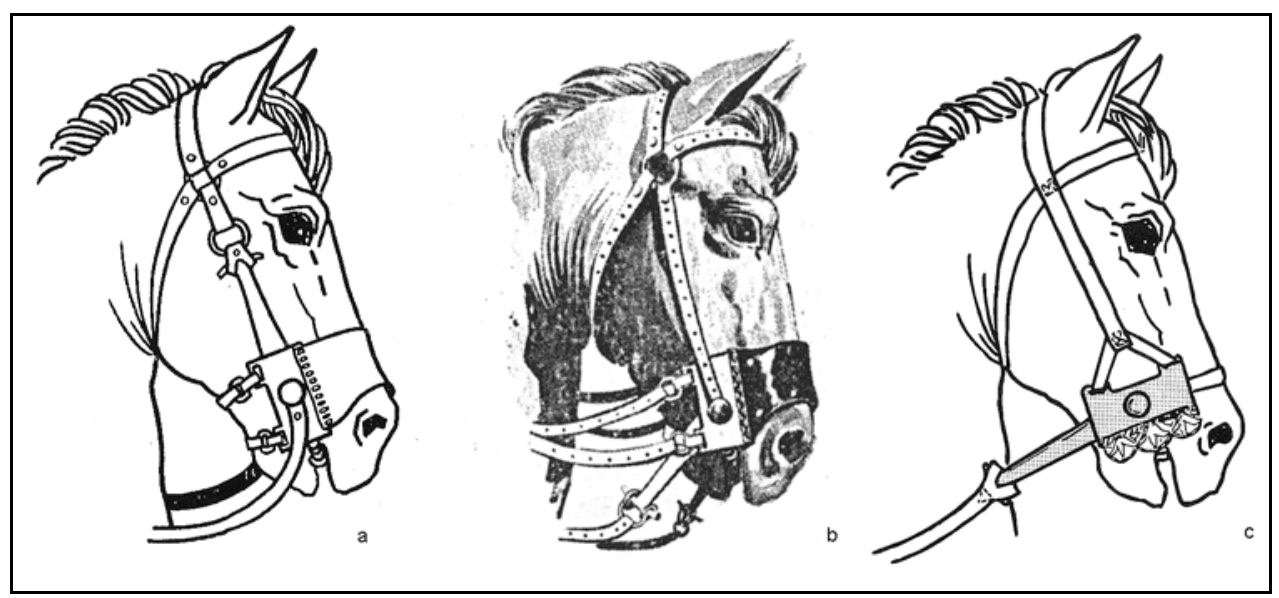

Fig. 13. Propuestas de reconstrucción de la cabezada de los équidos de La Joya. a.- y b.- según Garrido, Orta; c.- según Jiménez Avila.

A los bocados de La Joya deben añadirse, aunque la falta de contexto arqueológico impide precisar la cronología, los dos filetes articulados de bronce con cañones sogueados procedente de Ubeda la Vieja (Jaén) (Ferrer, Mancebo 1991:119 y Fig. 3.1; Jiménez Avila 2002:410) a los que le faltan las dos posibles grandes anillas para las riendas, al modo del bocado de La Ferradura, o quizá camas. La función como cama de unas piezas discoidales halladas en el conjunto, no aceptada por Ferrer y Albelda (1991:137), pero sí por Jiménez Avila (2002:227) es plausible, aunque sólo se conservan en el conjunto dos 'camas' para dos filetes -faltarían dos por tanto. De nuevo en este caso estos filetes parecen asociados a elementos de carro, incluyendo pasarriendas.

Por último, no entraremos en la cuestión sobre el carácter del famoso 'bronce Carriazo' (Blech 2003) ya que nueva evidencia inédita parece que podrá resolver la cuestión de su funcionalidad (Jiménez Avila, 2002:227, n. 78), y recordaremos también la pieza fragmentaria publicada por Jiménez Avila (2002:227) procedente de Luján (Badajoz) como posible cama de bocado.

Coincidiendo con Jiménez Avila (2002:229) los bocados orientalizantes hispanos presentan características únicas, hasta el punto de que cada ejemplar conocido define casi un tipo; sólo nuevos hallazgos o publicaciones permitirán identificar series. Son piezas muy elaboradas normalmente de cañones articulados sogueados, con camas rectangulares dotadas de perforaciones para colgantes (La Joya), de cama fundida con decoración antropomorfa o 
zoomorfa (si el bronce Carriazo resulta efectivamente ser una cama, junto con las piezas de Luján y otra pieza fragmentada hathórica de Sevilla estudiadas por Jiménez Avila), con cama circular (Ubeda la Vieja, si se acepta la identificación de los discos con camas), o de un modelo más sencillo sin camas similar a los del ámbito catalán pero en bronce y articuladas (Ubeda la Vieja).

En todo caso, éstos son modelos que no tendrán perduración en el tránsito al ibérico antiguo, ya que los bocados del tipo de Cancho Roano, fechados en el s. V a.C., presentan características diferentes como veremos. Los bocados hallados con cierto contexto arqueológico se asocian a carros y, aunque se haya llamado la atención sobre la existencia de marfiles de fabricación peninsular con imágenes de jinetes (Jiménez Avila 2002:231-232), su iconografía es tan claramente oriental que sólo de ella no puede deducirse la presencia de jinetes en el Orientalizante peninsular durante los siglos VII-VI a.C., y menos aún la de caballería (Quesada 1998b). Sin embargo, la lógica — sabemos de la monta de équidos en el Bronce Final, aunque poco o nada sabemos de los tipos de bocado - nos indica que en el Orientalizante también se montaba, aunque claramente el prestigio iba asociado a los carros; de todos modos, los bocados empleados en el tiro de caballos podrían con igual efectividad aplicarse a la monta, aunque como veremos en el s. V se aprecia una tendencia a una mayor severidad con la aparición de púas.

A una fase cronológicamente algo posterior, fechable en principio en el s.V a.C. - sobre todo por el conjunto de Cancho Roano- (Maluquer, 1983:56;) pertenece otra serie de bocados articulados, con cañones dotados de púas y grandes camas de bronce que Maluquer (1981 y 1983) clasificó en dos tipos: el 'A' de placa con dos prótomos de caballo (Fig. 14) y el 'B' con una gran placa calada con figura humana bifronte y dos prótomos de caballo (Fig. 15), tipos que han sido reexaminados recientemente y puestos en contexto con piezas idénticas - algunas quizá incluso fundidas en el mismo molde - halladas en otros yacimientos extremeños, andaluces y del sureste (Quesada 2002-2003, Blech 2003) (Fig. 16). En conjunto, ambos tipos pertenecen a la misma tradición cultural y la extrema similitud de ejemplares hallados en toda la mitad meridional de la Península ibérica hace pensar bien en artesanos itinerantes, bien en un taller que distribuiría en una amplia zona ( $v$. infra).

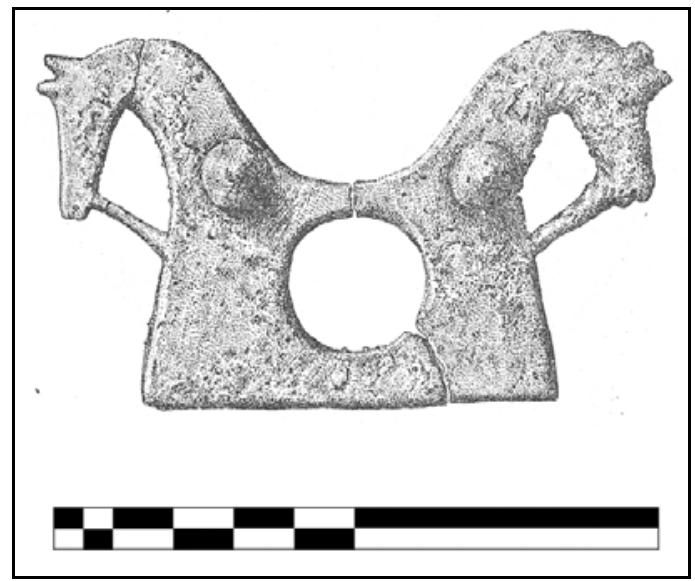

Fig. 14. Cama de bocado de tipo 'A' procedente de Cancho Roano (según Maluquer 1981).

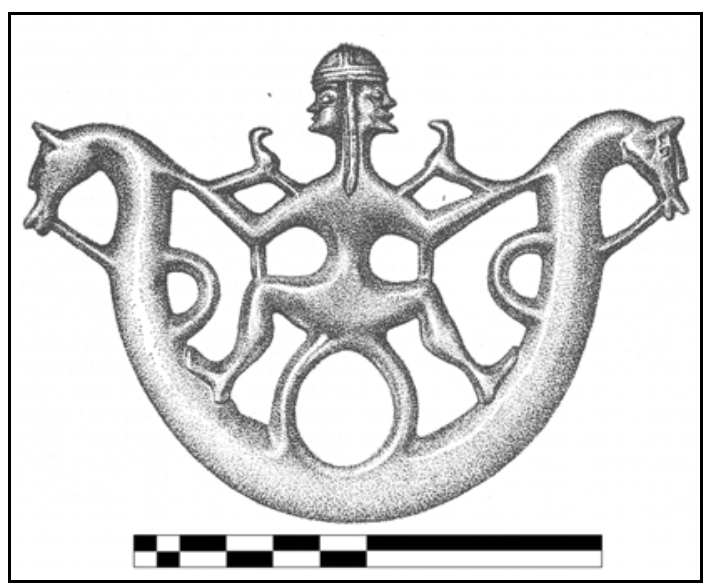

Fig. 15. Cama de bocado de tipo 'B' procedente de Cancho Roano (según Maluquer 1983). 


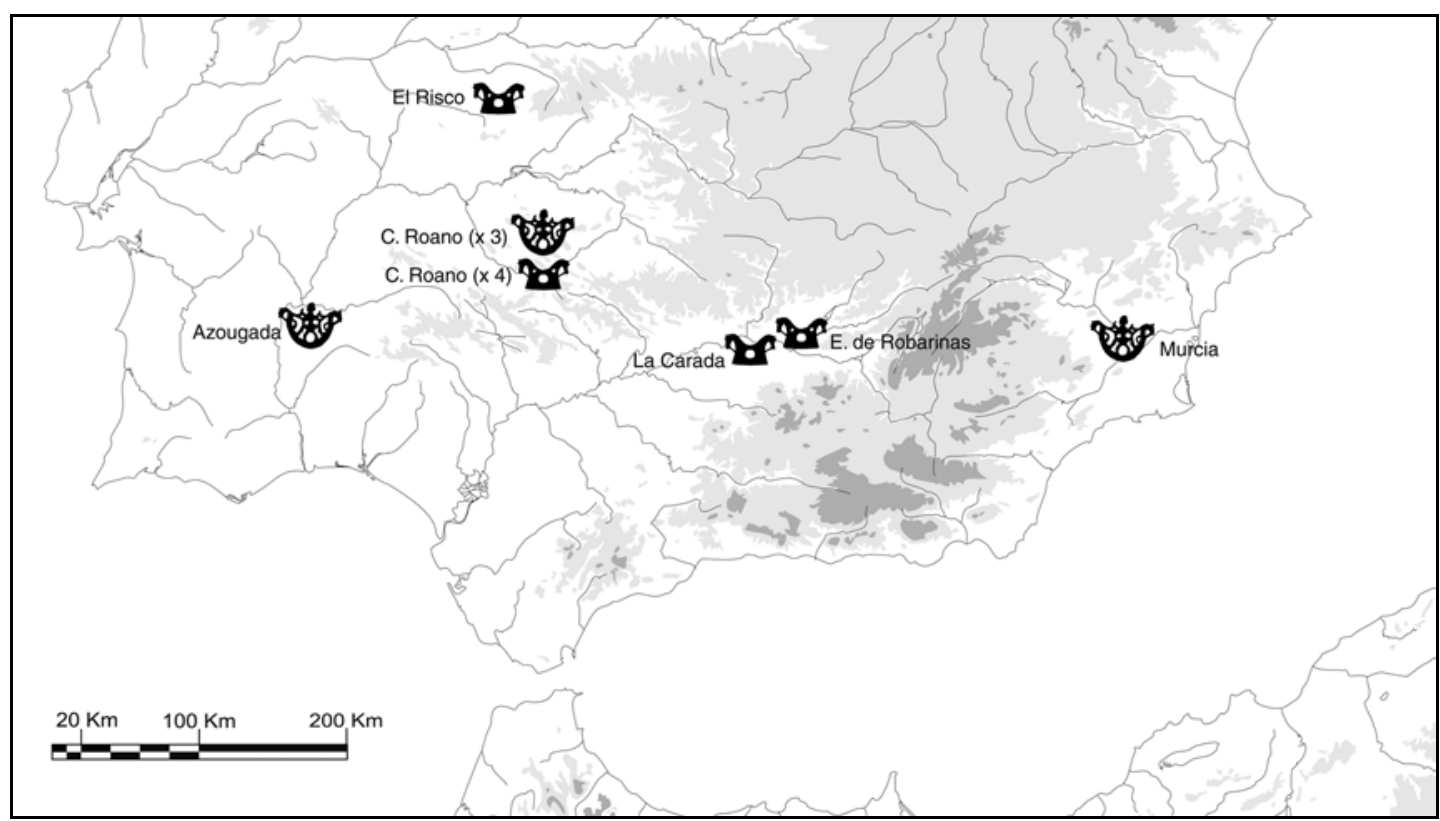

Fig. 16. Dispersión de camas de bocado con prótomos de caballo de los tipos A y B de Maluquer (a partir de Quesada 2002-2003).

Pese a la diferente forma de la cama, ambas variantes perteneces a un mismo tipo, severo, para el que se han propuesto dos reconstrucciones. Anillas en el extremo de cada cañón de la embocadura sirven para sujetar las riendas. Las dos camas tienen amplias perforaciones para que pasen los cañones, y orificios para remaches que sujetarían las correas de la cabezada. En conjunto, un tipo de brida relativamente sencillo, similar a otros mediterráneos de los siglos VII-IV a.C. ( $c f$. Anderson 1961, Pl. 19; Donder, 1980:Taf. 42 =Fig.7 de este artículo). En las Figuras 17 y 18 presentamos una probable reconstrucción de entre varias posibles, sin campanillas y con una configuración de cabezada diferente a la mantenida por Maluquer, quien daba un uso diferente a los remaches de los laterales de la cama, como sujeción de una pieza de cuero. Obsérvese cómo en esta cabezada, un sólo nudo en una de las quijeras permite soltarla, mientras que las correas unidas a los discos van fijas, como se deduce de los remaches que llevan esas fáleras. Por tanto la reconstrucción de esta cabezada se adapta bien a los elementos conservados. Nótese también que no requiere muserola ni frontalera. Para Maluquer (1983:56) las camas broncíneas se forraban al interior con una lámina de cuero, sujeta por los remaches de cabeza cónica (Blech 2003:Fig.2c). No estamos convencidos: el cuero no sirve ninguna función práctica, y además en el caso de la pieza que nos ocupa estropearía todo el efecto visual del calado. Creemos más bien que en este tipo de cama, asociada a una embocadura de cañones articulados con púas destinadas a impedir que el bruto mordiera el bocado, el orificio principal bajo las piernas de la figura humana serviría para pasar la embocadura, mientras que los dos laterales servirían para sujetar las correas de la cabezada, en particular quijera y quizá muserola (Fig. 17). Tampoco estamos del todo convencidos con la reconstrucción publicada por Maluquer (1983:59, Fig. 15) y aprovechada en parte por Berrocal para (en esto acertadamente) considerar del mismo tipo los bocados con cama de tipo 'A' o de prótomos de caballo de Maluquer (Berrocal, 1998:Fig. 20.6). Nos referimos a que, en nuestra opinión, las púas del lateral del bocado no servirían para sujetar verticalmente la cama, quedando al exterior de la misma como creía Maluquer (1983:52), sino 
que forman parte integral de un método destinado a evitar que el caballo levante la embocadura con la boca para colocarla sobre la dentadura, anulando así la acción del bocado (sobre la función de estas púas, ver por ejemplo Jenofonte, De la Equitación 9.6-9; ${ }^{7}$ además, Anderson,1961:54 ss.); por tanto ambos juegos de púas quedarían al interior de la cama. Sin embargo, tampoco se trata de herir al caballo, de ahí que en uno de los ejemplares de Cancho Roano las púas, afiladas en el molde, se encuentren limadas, para evitar dañar la delicada lengua, boca y paladar del caballo (Fig. 18). Del mismo, modo, si el colgante colosal con campanillas efectivamente pertenece al este atelaje, creemos que debía pender de otra parte, quizá de un elemento de carro, y no del extremo de la embocadura. En caso contrario, los colgantes confundirían al caballo al recibir una ayuda, ya que penden del extremo de la embocadura sobre el que también ejerce su efecto la rienda manejada por la mano del jinete. En tal caso, las señales emitidas por el jinete serían en parte contrarrestadas por el propio peso y movimiento de los colgantes.

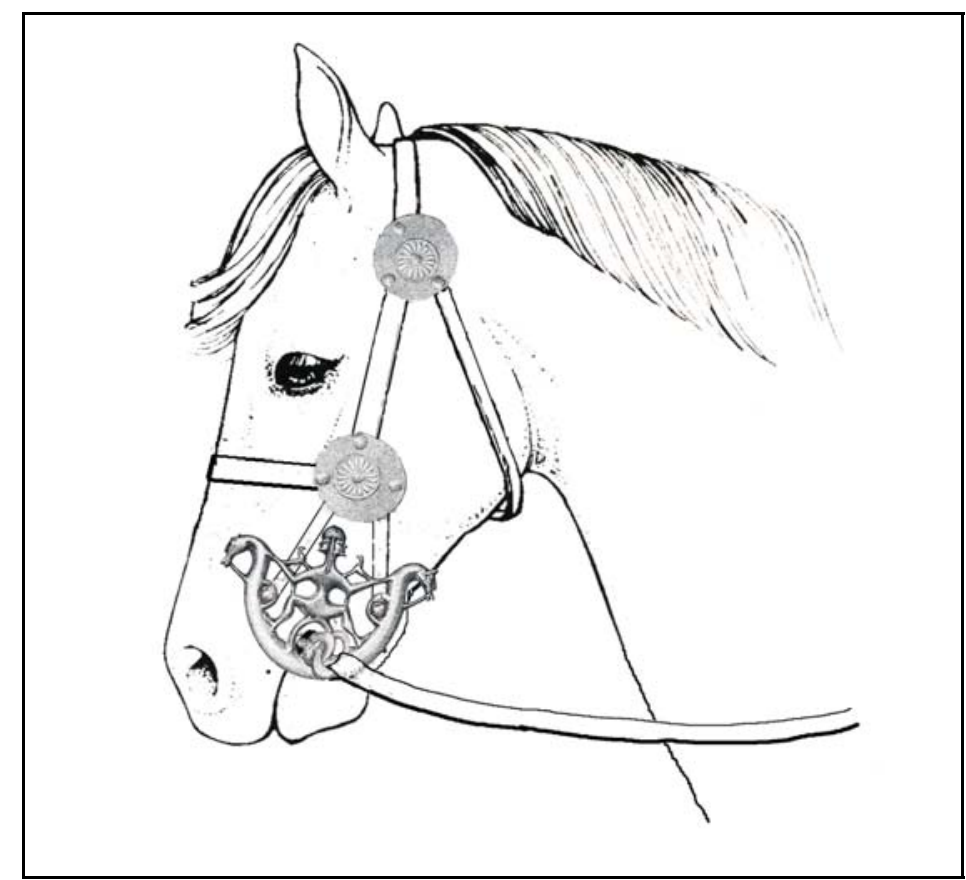

Fig. 17. Posible reconstrucción de cabezada con un bocado de tipo 'B' de Maluquer (según Quesada 2002-2003).

La longitud interior de la embocadura de estos bocados es de 12-12.5 cm., sin contar con el ángulo de la articulación. Este tamaño se aproxima más a los bocados del norte de Italia que a los centroeuropeos, más pequeños (Balkwill, 1973:439-440). Aunque esos datos se refieren a fechas algo anteriores, nos indican caballos de boca no excesivamente pequeña para el periodo (aunque recordemos que por lo general la talla de estos animales no era superior a la de un pony según los criterios actuales).

7 «Es preciso poseer, al menos, un par de bocados. Uno de ellos, que sea suave, con las anillas portarriendas bastante grandes; el otro, con las anillas pesadas y pequeñas y la embocadura punzante como un erizo, para que, cuando lo tome, no pueda sufrir su aspereza y lo suelte». (Trad.O. Guntiñas para la BCG, modificada en los términos técnicos por el autor). Cuanto menores las anillas pasarriendas, más directa la acción ( $c f$. Britton 1997:30). 


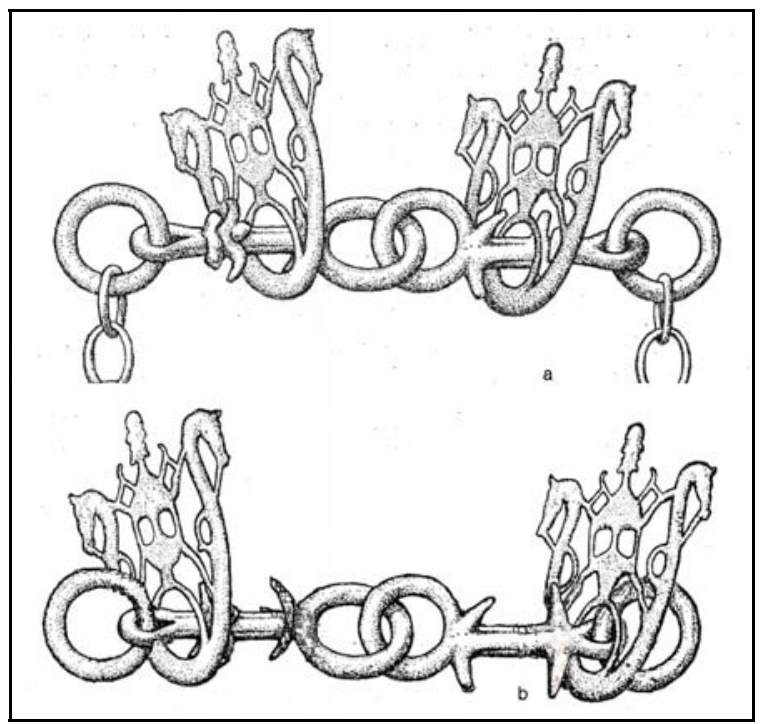

Fig. 18. Reconstrucciones alternativas de un bocado con camas elaboradas según Maluquer 1983) y Quesada (2002-2003).

Todo indica que tanto en Cancho Roano (Maluquer 1981, 1983, Quesada 20022003:233; Blech 2003:161 ss.) como en el caso de la placa de tipo B de Azougada (Gomes 2001) estos bocados se asocian a pasarriendas y otros elementos de carro. Los que cuentan con mejor contexto arqueológico son sin duda los que pertenecen al conjunto de Cancho Roano 'A' (en último lugar, Celestino, 2001:30 ss.; Blech 2003). Las diferentes camas se han hallado siempre asociadas a otros elementos de atelaje, tanto en el corredor $\mathrm{H} 2$ como en la zona de ofrendas de $\mathrm{H} 5$ y en la de almacenamiento H8, así como en el exterior del edificio principal, probablemente en la zona de S1-S6. Maluquer opinaba en 1981 que este tipo de bocado sería propio de un «caballo de batalla de algún jinete de fama» (Maluquer 1981:330) y lo asociaba a las armas de hierro aparecidas en el vano entre la entrada E1 y el corredor E2. Sin embargo, y aunque estos bocados pueden ser usados para la monta, a nuestro juicio hay razones para pensar que corresponden a atelajes de carro ceremonial, e incluso podríamos llegar a pensar ( $\mathrm{y}$ dado que hay elementos para formar una pareja de bocados de tipo 'A' $\mathrm{y}$ una de tipo ' $\mathrm{B}$ ') en una cuádriga con los caballos exteriores llevando bocados con camas muy elaboradas de tipo 'B', y los interiores las camas más sencillas de tipo 'A', mientras que las embocaduras, articuladas y con púas, serían idénticas, facilitando el gobierno del tiro. Sin embargo, esto sería exagerar, puesto que las camas aparecieron en puntos diferentes y una de ellas, la hallada en $\mathrm{H} 8$, tiene una decoración de círculos incisos que no casa con del todo con cualquier posible pareja (Maluquer, 1983:Fig. 11). Con todo, la asociación a un carro tiene apoyos adicionales. Por un lado, la muy elaborada y relativamente frágil estructura de este tipo de bocado en bronce parece que cuadra más con un vehículo de lujo que con un bocado de monta. Así, en el propio Cancho Roano hay un elemento de atalaje en hierro más basto, típico de la Meseta Norte (Maluquer, 1983:117, Fig. 49; Blech 2003:166, Fig. 6), del tipo 6 de la clasificación diseñada recientemente para Carratiermes (Argente, Díaz, Bescós 2001:75 y Fig. p. 72, nuestra Fig.8), así como una clara cama de bocado en hierro de tipo curvo (Blech 2003:164) que parecerían más adecuados para la monta y doma. Por otro lado, no faltan en Cancho Roano otros elementos asociados al caballo montado, como el conocido caballito de bronce hallado en 1990 en al estancia O1 (Celestino, Julián, 1991). 
Además, tanto en Cancho Roano como en Azougada las camas de bocado de posis o despotes theron se asocian, tanto en su contexto concreto como en el general, a claros elementos de carro, como pasarriendas de los tipos II y III de Jiménez Ávila y Muñoz (1997:Figs. 11 y 12), esto es, de anilla simple y de refuerzo, que Maluquer en principio consideró elementos de bocado (e.g. Maluquer, 1981:408, pie de Lám. XL). Otra pieza de Cancho Roano tiene paralelos en los atelajes de carro hallados en la Joya (barra de bronce con calado central rectangular que ya hemos discutido antes (Garrido, Orta, 1978:83, Fig. 49 y Maluquer, 1981:327, Fig. 39). Además, tipos de bocados muy emparentados a nuestros tipos 'A' y 'B' aparecen indudablemente asociados a carros en tumbas etrusco-itálicas (e.g. la biga de Roma Vecchia, de la segunda mitad del s. VI a.C., $c f$. Emiliozzi, 1997b:201 y Colonna, 1997:21) aunque hay que reconocer que en otras tumbas de carro etruscas aparecen también bocados de hierro mucho menos elaborados, como en Vetulonia (Cygielman, 1997:269) o en Capena (Mangani, 1997:289).

Por último, otras piezas del tipo (Fig. 16) proceden de regiones donde conocemos por otros elementos la existencia de carros ceremoniales entre los siglos VI-V a.C., que no serían exclusivos de Cancho Roano ni mucho menos. De hecho, el creciente número conocido de, por ejemplo, pasarriendas, demuestra la extensión de su uso en Andalucía y el Sureste, e incluso en otras regiones (Jiménez, Muñoz, 1997 passim; Jiménez Avila 2002; Ferrer, Mancebo, 1991 passim).

Aunque para las únicas piezas con contexto arqueológico - las de Cancho Roano- conviene como se ha indicado una fecha del s. V a.C. (Maluquer, 1983:56), es probable, dados los paralelos conocidos, que estos bocados tengan una historia más larga, que podría remontarse en origen al s. VI a.C., y por tanto a la fase B del santuario extremeño. Las piezas halladas fuera de este lugar no pueden ser datadas con facilidad, pero en Robarinas, El Risco y Azougada una fecha de fines del s. VI no está más fuera del lugar que una del V a.C. Aunque Maluquer creía que los ejemplares de Cancho Roano podían ser anteriores a los modelos itálicos de iconografía comparable (Maluquer, 1983:57-58), la datación de algunos de éstos en tumbas fechadas en el s. VI a.C. no permite sostener esta idea (e.g. Buranelli, 1997:202; Colonna, 1997:21, Fig. 8).

J. Maluquer insistía una y otra vez en los años ochenta en negar la vinculación orientalizante de estos objetos. Así, consideraba que el supuesto carácter 'orientalizante' de muchos de los objetos hallados en Cancho Roano era un 'espejismo orientalizante del que hacen gala algunos de nuestros investigadores...' (Maluquer 1981:292). Insistía, aún más, en que se trata de 'un mero recurso que muchas veces se ha utilizado también en España'. (1983:56). Esta línea ha sido seguida también por el reciente trabajo de Jiménez Avila (2002:229). Sin embargo, con el paso de los años, los hallazgos italianos muestran su anterioridad y no posterioridad a los hispanos, y en general parece claro que estos bocados se insertan en un contexto general de 'orientalización' cultural en la formación de lo ibérico, a partir de mediados del s. VI a.C. Ciertamente, los bocados de este tipo se alejan estructural y formalmente del único bocado completo verdaderamente 'orientalizante' que conocemos, el de la Sepultura 17 de la Joya, cuyos paralelos han de buscarse - aunque sin demasiada cercanía formal - en el extremo del Mediterráneo Oriental, y que se debe datar probablemente en la primera mitad del s. VII a.C., muy lejos de las camas que nos ocupan (Argantonio, 2000:288 ss.;Fernández Jurado, 1988-89:226). En cuanto al funcionamiento mecánico, y también en el espíritu de la decoración de las camas, los paralelos más próximos al tipo de bocados que nos ocupa están, como ya viera Maluquer a principios de los años ochenta, en Italia y no en Centroeuropa (Maluquer, 1983:56) donde, por otra parte, los modelos de la Edad del Hierro presentan, al menos en Europa centro-oriental, una fuerte influencia helénica ( $c f$. Werner, 1988) mientras que los modelos de tipo galo con grandes anillas, o los de barbada, son también diferentes, al igual que sus antecesores hallstáticos (Blakwill 1973). El repertorio itálico de von Hase 
(1969) recoge por ejemplo un peculiar tipo de cama en creciente rematada en ambos extremos por sendos pares de prótomos equinos, cada uno de ellos perforado para sujetar las correas de la cabezada y en concreto de la quijera. Si se recorta uno de los extremos de la cama y se amplía, tenemos casi exactamente una cama de bocado del tipo ' $A$ ' de Maluquer (von Hase, 1969:Taf. 22) (Fig. 19), y estamos tentados de creer que eso es lo que sucedió ${ }^{8}$. Sin embargo, en Etruria no se dan que sepamos los cañones con púas 'de erizo' que sin embargo abundan en el Próximo Oriente desde la Edad del Bronce, y en Grecia durante toda la Edad del Hierro, y este es un dato que nos obliga a mirar más hacia el este, alejándonos de Italia ${ }^{9}$.

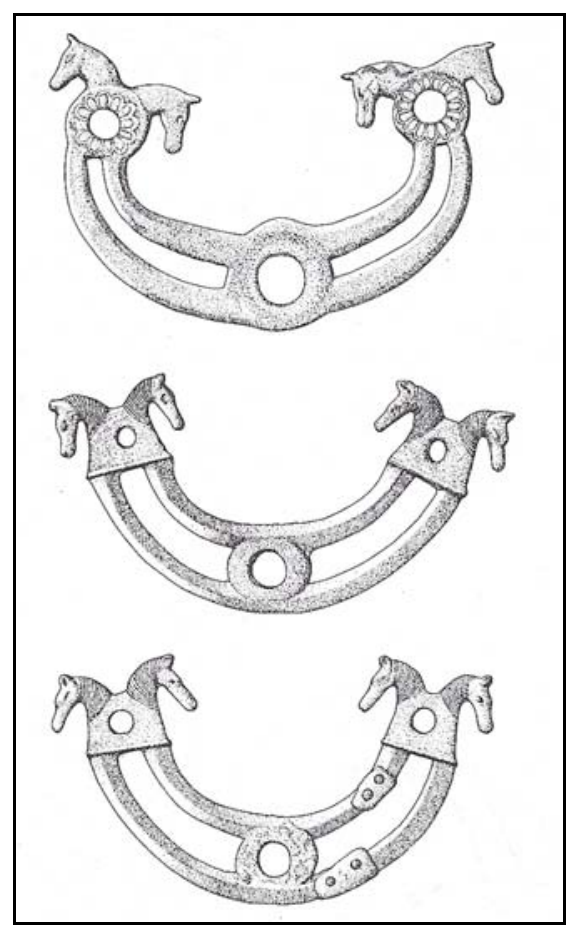

Fig. 19. Camas de bocado de caballo itálicas en bronce con prótomos equinos (según Von Hase 1969).

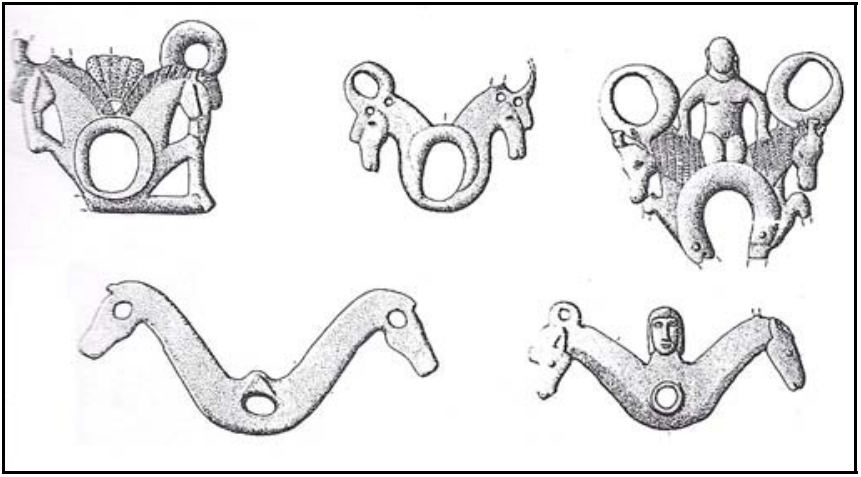

Fig. 20. Bocados griegos con prótomos equinos (según Donder 1980).

En efecto, el catálogo de bocados griegos y chipriotas elaborado por Helga Donder (Donder 1980) nos obliga a recordar que, aunque quizá más lejanos formalmente, en espíritu hay bocados griegos de los siglos VII y VI a.C. que presentan también prótomos equinos pareados y de espaldas (tipos III y IV de Donder, Taf. 42, nuestra Fig. 7) que están muy próximos a los hispanos, incluso apareciendo una figura humana entre ellos (e.g. Donder, 1980 Taf. 6, con ejemplares de Delfos, Olimpia, Samos, etc.) (Fig.20). Además, abundan los

8 Pero recordemos también la notable iconografía del guerrero de Castiglione de Ragusa de Sicilia (en Hesperia 16).

9 Nos llama la atención que el tipo itálico que más recuerda los bocados hispanos (Bogenknebel mit Doppelpferdekopfende) (von Hase, 1969:40,24-25) sea más abundantes en el Piceno que ne la Etruria propia, aunque se crea originarios de la segunda región (Colonna, 1997:21) ,ya que aparece también por ejemplo en Roma Vecchia (Emiliozzi 1997b:201. Teniendo en cuenta lo que sabemos sobre el origen de la machaira itálica y su posterior transformación en la falcata ibérica, la coincidencia es curiosa Quesada, 1997:145 ss.). 
modelos con púas. A su vez, estos tipos 'equinos' están muy emparentados con bronces del Luristán (al respecto Herrmann, 1968 passim, y especialmente Abb. 3 y su reconstrucción de brida en Abb. 4, similar a la propuesta por nosotros en la Fig. 17). lo que nos lleva a definir una suerte de koiné en la que no siempre es fácil discernir el origen.

No es aquí nuestro objetivo discutir el significado profundo de los prótomos de caballo, aves y personaje bifronte; sí, en cambio, las características, estructura y funcionamiento de los bocados. En todo caso, parece claro que estamos ante un tipo de bocados asociados a contextos ceremoniales, probablemente a carros procesionales, con un papel ornamental evidente que no debe ocultar un significado profundo de índole religiosa, asociado a una divinidad protectora de los équidos que aparece por todo el Mediterráneo y que tendría especial éxito, y perduración, en la Península Ibérica, donde Cancho Roano parece cada vez más asociado a un culto en que los équidos tienen un papel muy relevante, a juzgar por el sacrificio de diecisiete de ellos en el foso que rodea el conjunto (Celestino, 2001:57; 2001b:52-53). Que la tradición iconográfica acompañó durante siglos a la religiosidad parece probado por la extraordinaria extensión del motivo del personaje entre équidos, en los relieves — sólo quizá más tardíos— ${ }^{10}$ del llamado 'domador de caballos' recientemente reexaminados por Marin Ceballos y Padilla (1997), o de los propios exvotos equinos. Piezas además como los pequeños colgantes broncíneos con estilizaciones del domador de caballos, halladas en puntos tan distantes como La Osera en Avila (Baquedano, 1990:282 y Fig. 9) o Coimbra en Murcia (García Cano et al. 1997 Fig.5.2 ) y la Hoya de Santa Ana en Albacete (Abascal, Sanz, 1993:153 n. 338), siempre posteriores a principios del s. IV a.C., testifican esta notable perduración iconográfica.

Dada la dispersión que van alcanzando en fechas recientes (Fig. 16), no está claro que como creía Maluquer estos bocados fueran fabricados solo en un taller próximo a Cancho Roano. Pero sin duda son productos locales, pertenecen a una tradición muy elaborada y normalizada, e incluso es probable que los ejemplares conocidos pertenezcan a un número muy reducido de moldes; cabe incluso pensar que fueran los moldes de estas piezas de lujo, y no las piezas mismas, los que se movieran en manos de artesanos itinerantes (Quesada et alii 2000; Izquierdo, 2000:381 para el concepto y su creciente viabilidad). Responden todavía a esa tradición orientalizante en la que la 'calidad' era un factor primordial en los procesos de ostentación (sobre el concepto cualitativo frente al 'cuantitativo' más característico del mundo ibérico a partir del s. IV a.C., Quesada, 1998a). Sin embargo, y como prueba su misma asociación a elementos férreos mucho más sencillos en el propio Cancho Roano (Blech 2003:164-166), pertenecen a un momento crepuscular de aquella época, comparable quizá al ajuar encontrado bajo el monumento de Pozo Moro en Albacete, en el que este tipo de piezas metálicas de imaginería muy recargada y elaborada estaba en decadencia.

Sobre los bocados de caballo en el mundo ibérico y celtibérico (siglos IV-I a.C.) (Figuras 21,22,23).

A partir de finales del s. V a.C. se impuso por toda Iberia una tradición diferente de bocados férreos, más sencillos y bastos, más generalizados también (en la misma línea, Blech 2003:175), en un proceso similar al que se aprecia por ejemplo en las armas. A partir del 400 a.C. aproximadamente, sería extraordinario encontrar bocados de un tipo muy elaborado en una sepultura de guerrero ibérico o celtibérico: la normalización, y la concepción básicamente acumulativa de la ostentación, han desplazado al concepto cualitativo de los siglos anteriores.

10 Aunque precisamente la proximidad iconográfica e ideológica ha llevado a Martín Almagro-Gorbea a fechar restos relieves desde el s.V, haciéndolos pues contemporáneos con los arreos que analizamos (Almagro 1996:119). En la misma línea Marín y Padilla (1998:470 ss.). 


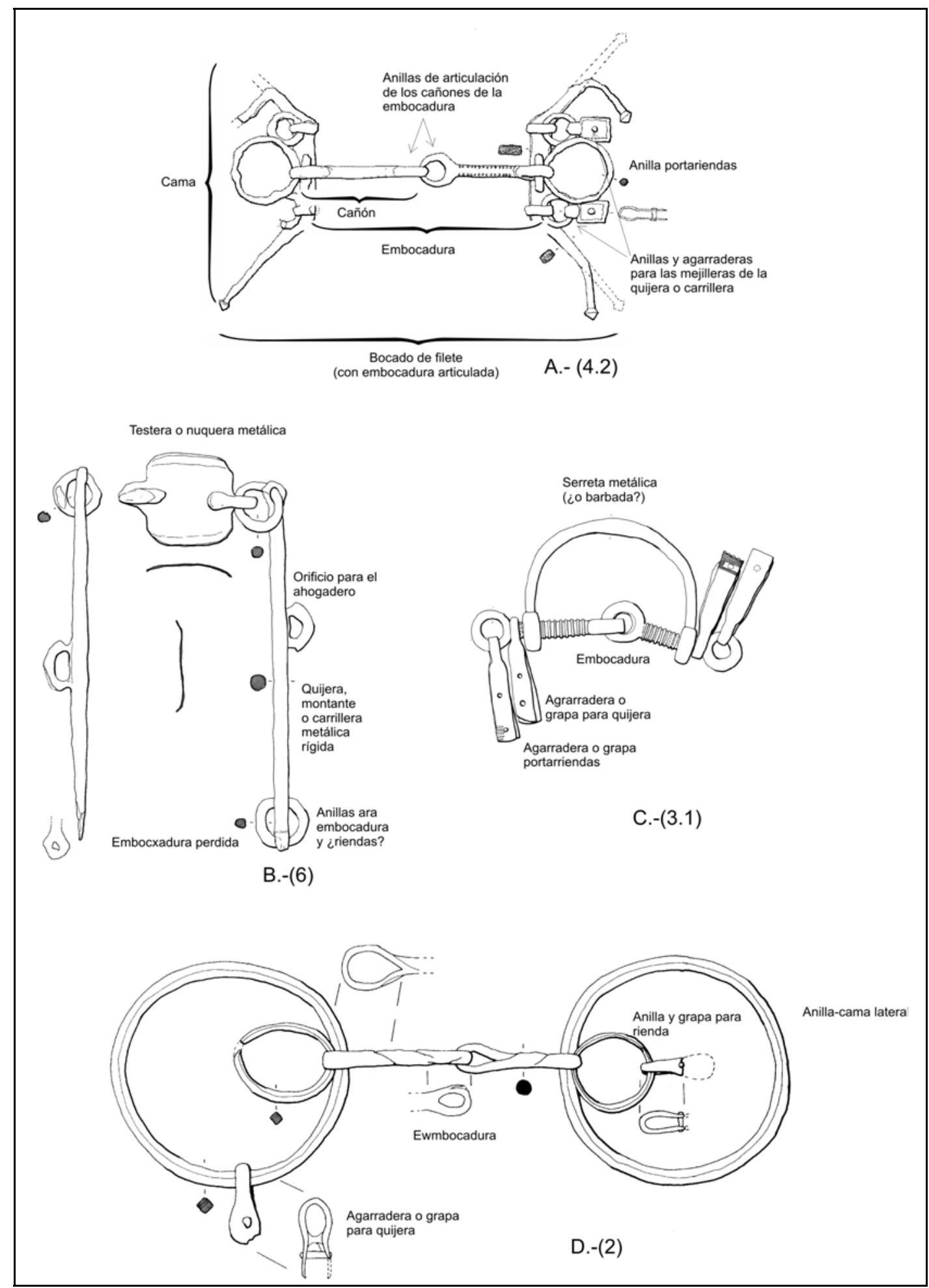

Fig. 21. Denominación de elementos en los principales tipos de bocados peninsulares de la Segunda Edad del Hierro. Entre paréntesis se indican, para comodidad de uso, las denominaciones de la clasificación de Argente, Diaz, Bescós (2000) reproducida en la Fig. 8. 
No existe en la actualidad ni un corpus detallado ni un estudio tipológico sistemático de los bocados de caballo de la Segunda Edad del Hierro en la Península Ibérica, trabajo actualmente en curso por nuestro equipo, aunque sí algunos estudios parciales. (ver infra). Conviene por tanto repasar la historia de la investigación para poder presentar un estado actual de la situación de estos estudios.

Las excavaciones realizadas a principios del s. XX en la zona nuclear celtibérica por Aguilera y Gamboa, Marqués de Cerralbo, en especial las de Aguilar de Anguita (Aguilera y Gamboa, 1911, 1916), así como posteriormente las de su colaborador Juan Cabré Aguiló, en especial las de Atienza (Cabré 1930), Cogotas (Cabré 1932) y La Osera (Cabré y Molinero 1950) proporcionaron, entre otros materiales de extraordinario interés, conjuntos importantes de bocados y otros arreos de caballo de la Segunda Edad del Hierro, prácticamente desconocidos por entonces. Los primeros de ellos - los excavados por Cerralbo - fueron recogidos y publicados en el trabajo de Sandars (1913) sobre las armas de los Iberos (y Celtíberos), que inauguró la costumbre de asociar los elementos de monta al estudio del armamento. El segundo lote, procedente de las excavaciones de Cabré, se descubrió con posterioridad al estudio de Sandars, que sería durante muchas décadas el único trabajo de conjunto. Distinguía Sandars, empleando casi en exclusiva material de Aguilar de Anguita, entre bocados — de filete articulado de diversos tiposy cabezón o serreta metálica, y tendía a enfatizar los paralelos mediterráneos.

En efecto, Cabré conoció decenas de magníficos bocados de caballo y otros elementos de arreos excavados por Cerralbo en necrópolis como Aguilar de Anguita, que se conservan en su Archivo Fotográfico. Sin embargo, y dado que la monumental Páginas de la Historia Patria... nunca se publicó, conservándose sólo algunos manuscritos y tomos de láminas en los Museos Arqueológico Nacional y Cerralbo de Madrid, el efecto final fue como si estos objetos nunca se hubieran exhumado, ya que ni en una primera fase (en vida del marqués) ni en una segunda (entre 1922 y 1947) tuvo Cabré ocasión de proceder a su estudio detallado. La breve obra de Cerralbo (Aguilera y Gamboa 1916), con su breve descripción de unos arreos que conocía bien y no se molestó en explicar en detalle (pp. 41 ss.), no es sustituto de la necesaria publicación en detalle de las necrópolis, como tampoco el breve análisis casi contemporáneo de Sandars sobre los mismos materiales (1913:80-82). Al parecer, Cerralbo realizó un estudio inédito sobre los bocados de caballo de sus excavaciones, que no hemos localizado, y que es citado por Cabré en su estudio sobre Altillo de Cerropozo (Cabré 1930: 25-26). Sea como fuere, cuando el Marqués falleció, la mayor parte de los materiales de sus excavaciones pasaron al Museo Arqueológico Nacional (Barril, 1993a), donde algunos de ellos fueron exhibidos, para ser luego en su mayoría retirados a almacenes, donde han permanecido desde entonces, muchos de ellos sin restaurar y todavía con las antiguas etiquetas hechas a mano. En este momento todo ese material ha sido fotografiado y dibujado y se encuentra en estudio por nosotros.

Por otro lado, y aunque el propio J. Cabré pudo realizar publicaciones adecuadas de muchas de sus excavaciones, una de las más importantes, la Osera, quedó incompleta a su fallecimiento. En cuanto a los interesantes datos de Atienza y Cogotas, donde aparecieron arreos de caballo muy completos, Cabré pasa de puntillas por ellos, quizá en espera de un detallado estudio posterior en colaboración con E. Cabré que no se produciría (obsérvese el detallado tratamiento de las espadas en el estudio de Atienza frente a la escasez de comentarios sobre los bocados, Cabré 1930:32 ss., y lo mismo en Cogotas, Cabré 1932) ${ }^{11}$.

11 A lo largo de sus trabajos, sin duda deudores de las técnicas de su tiempo, pero en todo caso más cuidadosos y detallados que los del Marqués de Cerralbo, J. Cabré fue dibujando los materiales con su hija Encarnación (nacida en 1911 y que muy joven colaboró en sus trabajos), empleando una técnica muy limpia y precisa de dibujo lineal que trataba de presentar la pieza tal y como era, en sus rasgos tipológicos fundamentales, y no tal y como estaba conservada (Baquedano, 2002:22). Estos dibujos de objetos metálicos, de una claridad y precisión notables, se han revelado con el tiempo más útiles que los dibujos sombreados que tratan de reflejar cada escamación del óxido, al tiempo que más baratos y rápidos de realizar. 


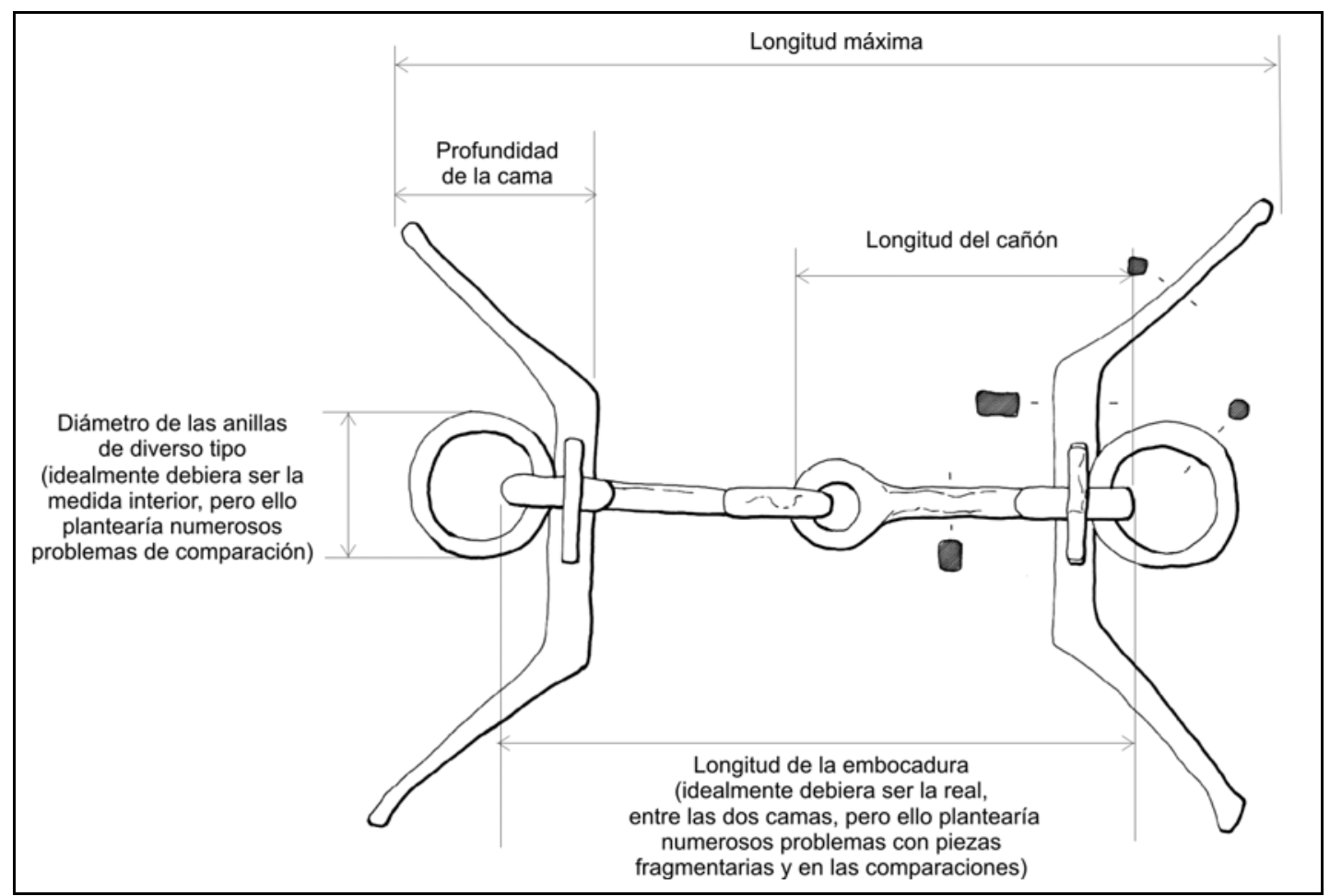

Fig. 22. Dimensiones básicas para la descripción de un bocado de filete.

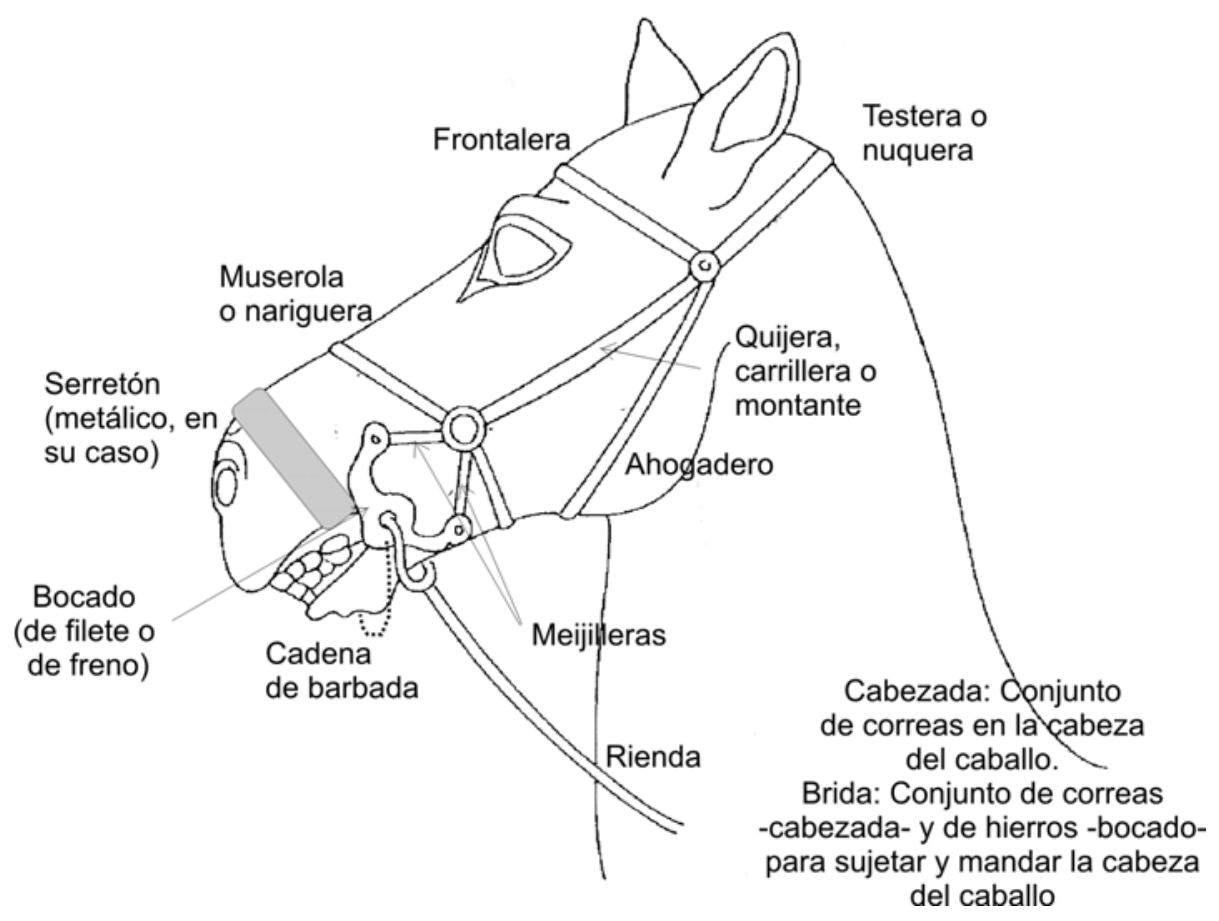

Fig. 23. Denominación de los elementos de la cabezada. 
La colaboración de Encarnación Cabré con su padre, iniciada muy joven en Las Cogotas y en el Altillo de Cerropozo de Atienza, dio lugar al comienzo de una Tesis Doctoral sobre el armamento de los celtas hispanos (Baquedano, 2002:23) que prometía tener una importancia decisiva, pero que en buena medida se vio frenada y luego detenida por los terribles acontecimientos de la Guerra Civil que estalló cuando Encarnación Cabré, a sus veinticinco años, estaba en el apogeo de su investigación. Las vicisitudes de la guerra, con las exigencias de salvamento del Museo Cerralbo, las injusticias sufridas por Cabré tras la guerra (González Reyero, 2002-2003:270) sus circunstancias familiares, y la necesidad de publicar algunos de los trabajos inconclusos de su padre, como la primera Memoria sobre La Osera (García-Soto, 2002:19 ss.; Baquedano 2002) impidieron la finalización de un trabajo de conjunto que sin duda hubiera sido seminal, a la vista de los artículos parciales que fue publicando entre 1934 y 1954 y sobre todo de su ponencia de 1990 en el congreso sobre Necrópolis Celtibéricas de Daroca.

El estudio de W. Schüle (1969:122-128) sobre las culturas meseteñas de la Edad del Hierro supuso un salto cualitativo importante, aunque al estar realizado en alemán su texto no alcanzó la difusión que hubiera merecido entre los investigadores españoles, que sin embargo han venido empleando sistemáticamente el corpus de láminas. Su enfoque básicamente evolutivo y centrado en las influencias de las estepas orientales y centroeuropeas (por otro lado en la línea general de su obra) tendía a infraestimar la tradición mediterránea y el peso de la tradición orientalizante, distorsionando en cierto modo el panorama futuro de la investigación que durante décadas no prestaría la atención debida al mundo ibérico (Quesada 2005). Sin embargo, Schüle no pudo conocer los bocados que en los últimos años vienen apareciendo en la zona catalana (supra) en contextos de los ss. VII-VI a.C. que enlazan con el ámbito norpirenaico al que él prestó especial atención (Schüle 1969:122-123) y que permiten establecer una doble corriente de influencias, continentales y norpirenaicas. Aún así, su consideración de un bocado de Almedinilla (Schüle 1969:Lám. 80.6 y p. 123) como ejemplo del tipo I de la clasificación de Jessen es un ejemplo de lo discutible de su aproximación, dados los insalvables márgenes cronológicos que él mismo reconoce.

Desde el trabajo de Schüle no ha habido grandes estudios específicos dedicados a los arreos de caballo, probablemente por la escasez de nuevos materiales con contexto. Salvo excepciones como el estudio de Baquedano sobre algunas piezas de la Osera (Baquedano 1990) o el más técnico análisis de G. Kurtz sobre los arreos de caballo en Cogotas (Kurtz, 1986-7) que constituye un intento valiente pero aislado de clasificación, el tema ha dormido hasta la actualidad. Kurtz sin embargo ya observaba dificultades con algunas definiciones tradicionales, como la de serretones (piezas metálicas sobre la nariz, Fig. 23) para piezas que deben ser frontaleras (ver Kurtz 1986-87:Fig. 9 para la prueba). En efecto, no ha sido hasta el año 2001 en que la publicación de la necrópolis de Carratiermes, con un repertorio suficientemente nutrido y contextualizado de objetos, ha proporcionado la que es probablemente primera y única sistematización de amplio alcance de este tipo de objetos desde los años sesenta (Argente, Díaz, Bescós, 2000:70ss.). Prueba del embrionario estado de la investigación de este tema es la ausencia prácticamente total de referencias bibliográficas de concepto o tipología (salvo la ya citada Meseta Kulturen... de W. Schüle), carencia observada con cierta melancolía por los autores (p. 81). Igualmente, el trabajo ha de comenzar por una breve explicación terminológica, primera en español aplicada a este contexto arqueológico ecuestre en muchas décadas. Lógicamente, en la época de Cerralbo, en la que el caballo era todavía elemento de transporte habitual, y en la que un aristócrata era casi por naturaleza un buen conocedor del mundo ecuestre, no se planteaban los problemas de terminología adecuada y específica que hoy se hace necesario replantear en todos los trabajos que empiezan a publicarse sobre la cuestión (por ejemplo, también Blech, 2003) y a los que no hemos sido ajenos nosotros mismos (Figs. 21, 22 y 23).

El trabajo de Argente, Díaz y Bescós es excelente, aunque las imprecisiones características en la terminología, que responden a diferentes tradiciones, permitirían discutir algunas de 
las acepciones del glosario (por ejemplo la equiparación de bocado y bridón, de filete y embocadura, o la definición del bridón como un sistema que se basa en 'el ejercicio de presión solamente en sentido de adelante a atrás' (p. 71). La clasificación en tres grupos de elementos (bocados, frenteras y elementos de ensamblaje) es correcta y ayuda a clarificar la terminología, además de que insiste adecuadamente sobre los aspectos funcionales. Los tipos de bocado definidos en Carratiermes (Fig. 8) abarcan la inmensa mayoría de los conocidos en otros yacimientos meseteños e ibéricos, aunque habrá que introducir numerosas variantes y algún tipo nuevo en la clasificación general que preparamos. Hoy por hoy es difícil precisar cronologías, ya que la mayoría de los tipos nacieron ya en la Edad del Bronce y su transmisión ya en hierro debió ser simultánea. Tampoco hay por ahora indicios claros de variación regional, ya que todos los tipos frecuentes en la Meseta se dan también en territorio ibérico donde, como ya hemos insistido en detalle en otro lugar, los bocados son mucho más raros (Quesada 1998b:173 ss.). Es necesario insistir mucho sobre cuestiones de detalle, como se verá por algunos casos que detallamos a continuación y que indican las dificultades todavía existentes.

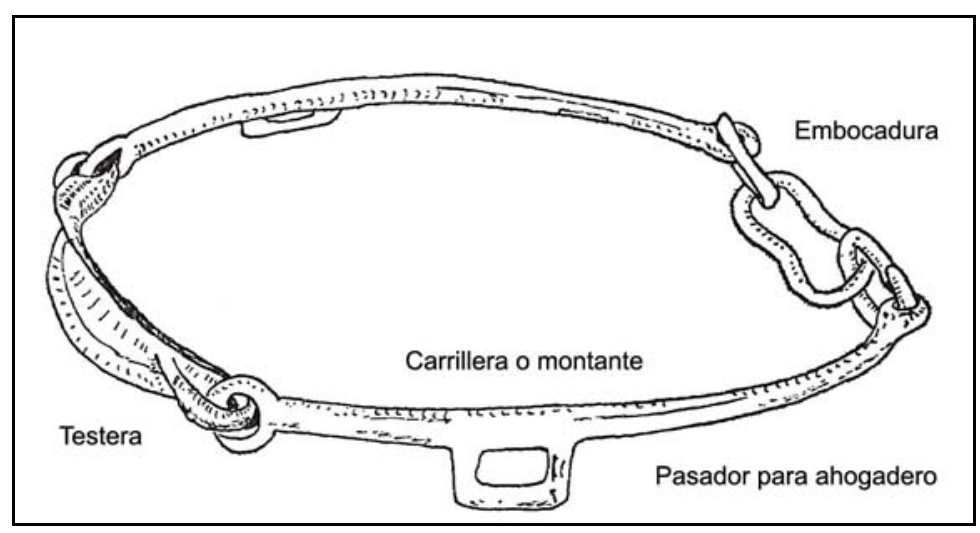

Fig. 24. Conjunto de bocada y nuquera unidos por quijeras rígidas. Pieza de bronce supuestamente hallada en Italia en el RGZ de Mainz. A partir de Schüle (1969:Abb. 13).

Es especialmente interesante —en la cuestión de la caracterización regional y de la existencia de tipos específicamente hispanos - el caso del peculiar modelo de cabezada semirígida o Tipo 6 de Argente, Díaz Bescós (Fig. 8, Fig. 21b), hasta ahora considerado característico de la Meseta, y que ahora se documenta también en La Serreta de Alcoy (Alicante) (Quesada 20022003b:97-98). Incidentalmente, este tipo que parecería en principio exclusivo de la Península, se ha documentado también - supuestamente- en Italia, ${ }^{12}$ donde un ejemplar publicado por Schüle sin procedencia precisa (Fig. 24) y conservado en el RGZM (Schüle 1969:127, Abb. 33) da la pista para la configuración completa de la parte metálica de la cabezada, con nuquera curva plana y embocadura peculiar que hemos podido documentar en La Serreta (Quesada 20022003b:Lám. XV). Por otro lado, la idea de convertir lo que casi con seguridad son enganches para ahogadero en sujecciones para la embocadura (Fig. 25) es — creemos- claramente errónea, y deriva de una suposición de Cabré en Atienza, a partir de otra de Cerralbo en Aguilar de Anguita donde se aprecia una superposición para la fotografía (Aguilera y Gamboa 1911:III, Lám. 41.2; Artiñano y Galdácano 1919:p. 13, n. 43; Quesada 2004:250; Quesada 1997:n.cat.

\footnotetext{
12 Aunque Schüle (1969:127) obviamente duda de esta procedencia y se adivina que plantea un origen hispano, aunque la pieza del RGZM es de bronce y las peninsulares todas de hierro.
} 
5921). Por otra parte, la aparición de una pieza tipológicamente muy parecida en un contexto romano imperial en Newstead (Escocia) abre nuevas posibilidades sobre la datación y expansión de este peculiar tipo que merece un estudio monográfico (Taylor 1975:Taf. 64.2)

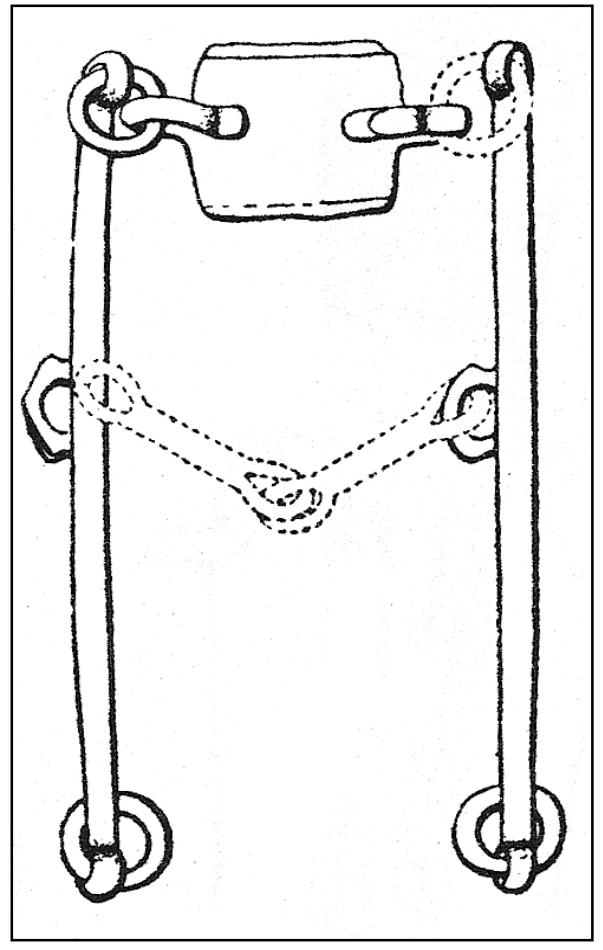

Fig. 25. Reconstrucción engañosa de la estructura de la cabezada anterior con los orificios para un ahogadero convertidos en sujecciones de embocadura -imposibles- a partir de un montaje fotográfico de Cabré sobre materiales de Altillo de Cerropozo (1930:Láms. I y XVII) seguido por Schüle (1969:Taf. 20.13).

Llama la atención en Carratiermes la existencia de un bocado de freno (llamado allí 'bocado de doma' o tipo 5) con desveno y barbada rígida (curb bit en la terminología anglosajona frente al más habitual snaffle), que tiene origen céltico (Anderson 1961:52-53; Hyland 1990:136 ss.) pero es extremadamente inhabitual en Celtiberia (otros ejemplos en Álvarez Gracia et alii, 1990:Figs. 15, 16) y en Villanueva de Teba (Stary 1994:158, Abb. 23), e inexistente en la zona ibérica, hasta época romana. Los autores (Argente, Díaz, Bescós 2001:75) se resisten a llamar bocado de freno a este tipo, como hacía el Marqués de Cerralbo (Aguilera y Gamboa 1916: 42), pero a nuestro juicio el marqués tenía razón en este punto, y el bocado ejerce una acción de palanca ya que la rienda se ajusta a una anilla muy por debajo de la barbada (Anderson, 1961:50$52)^{13}$. Obsérvese además que el bocado reproducido de Carratiermes es idéntico al curb bit de Newstead probado por A. Hyland (1993:55-57) (Fig. 9).

También es discutible la orientación proporcionada (Fig. 8 y Fig. 21) para el tipo 3, donde la pieza metálica curva se concibe como un serretón colocado sobre la nariz. Una alternativa es posible como barbada, y así es como A. Hyland interpreta la estructura del bocado de filete (snaffle bit) de Newstead (Hyland 1993:56, 57) (Fig. 9).

En cuanto al tipo 4.1 (Fig. 8), ya hemos analizado al comentar las piezas similares pero de 'camas' rectas de La Joya y sus paralelos en Cancho Roano y en yacimientos celtibéricos e ibéricos las dudas que se nos plantean, y que compartimos con Argente, Díaz y Bescós (2001:74).

No entraremos aquí en la compleja cuestión de muchos tipos complejos de cabezadas metálicas así como de frontaleras de arco metálico, que exigirían un estudio pormenorizado, bien iniciado por Argente, Díaz y Bescós (2001:76) para Carratiermes.

Es de lamentar que algunos otros estudios recientes - y modélicos- sobre necrópolis meseteñas no hayan podido prestar una atención similar a los arreos de caballo a la que ha obtenido Carratiermes, por la sencilla razón de que, sorprendentemente, no hay apenas arreos. Es el caso de la necrópolis vaccea de Las Ruedas en Padilla de Duero (Sanz Mínguez,

13 Aunque otros autores como Azzaroli dudan (1985:120 ss.) y la cuestión sigue abierta; pese a que Azzaroli parece tomar la barbada de bocados romanos de este tipo como embocadura ( $\mathrm{p} 120)$ : 'the mouthpiece is placed at the middle of two long cheekpieces. The curb is made of a metal bar bent in various shapes...' Da la sensación de que el autor convierte la embocadura con desveno en un serretón, siguiendo a Vigneron, de modo que la barbada o curb sería una cadenilla unida a la misma anilla de las riendas (ver su Figura 74). Es innecesario: la barra a mitad de la cama es la barbada; la pieza con desveno la embocadura. 
1997:454-456) o las del Raso de Candeleda (Fernández Gómez, 1997:102). Lo mismo ocurre con las grandes necrópolis ibéricas recientemente publicadas (Cabecico del Tesoro, Cigarralejo, Coimbra del Barranco Ancho, Cabezo Lucero, Castellones de Ceal...), donde los bocados y otros elementos de monta brillan por su ausencia.

\section{Jáquimas y narigones. Bozales metálicos.}

Conviene también llamar la atención sobre unas grandes anillas de bronce de unos 9-10 $\mathrm{cm}$. de diámetro, abiertas y con un sistema de cierre mediante un adelgazamiento en un extremo que encaja en un hueco del otro (Fig. 26), a veces identificadas como torques o brazaletes, $\mathrm{y}$ a las que ha venido a dar correcta explicación la sepultura intencional de un caballo en Burriana (Castellón) que posiblemente responda a un rito sacrificial (Fig. 27). Sobre su mandíbula, aparentemente en posición original, estaba una de las anillas del tipo que describimos (Mesado Oliver 2003). Las dudas que pudieran plantearse sobre la cronología del enterramiento, sin otros materiales que la anilla y algún fragmento de cerámica prerromana, incluyendo uno de Campaniense B (Mesado 2003:184), vienen a despejarse no sólo por la presencia de anillas similares en otros yacimientos ibéricos como La Serreta de Alcoi (Quesada 2002-2003b:96-97), Puntal dels Llops o Cigarralejo y Torre d'Onda (Quesada 20022003b:97; Mesado ibidem con referencias) sino sobre todo por paralelos de caballos enterrados con la misma anilla en posición sobre la boca en fechas similares en Hungría y en la zona paleovéneta (Quesada 2003:14-15) (Fig. 28).

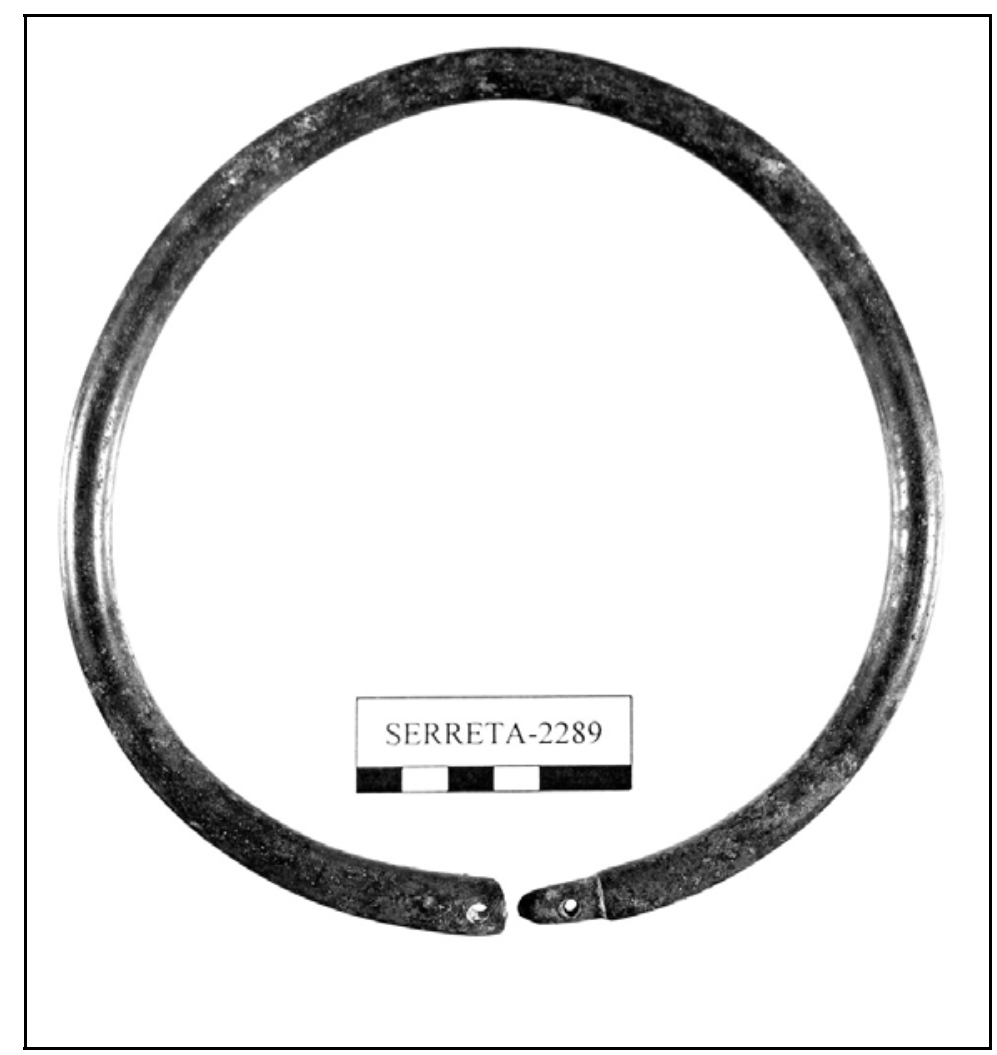

Fig. 26. Narigón de la Serreta (según Quesada 2002-2003). 


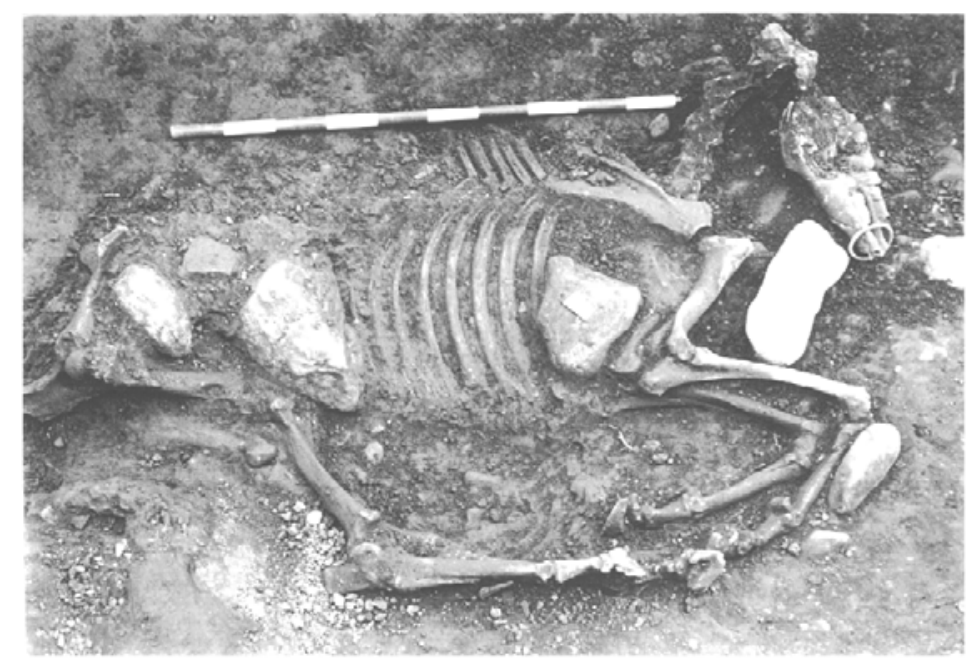

Fig. 27. Enterramiento de caballo de Burriana (Castellón) (según Mesado 2003).

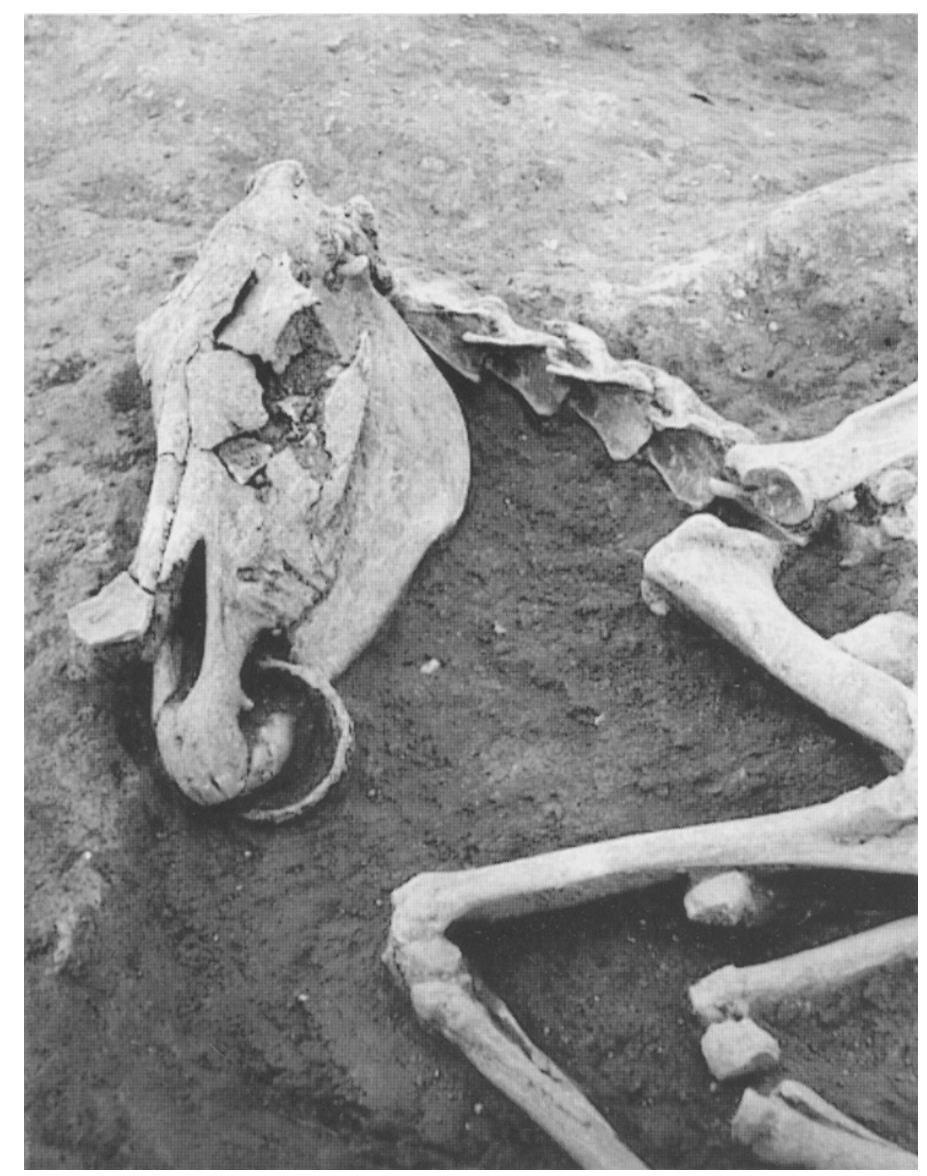

Fig. 28. Inhumación de caballo en Sopron (Hungría). S. II a.C. (Según Jerem). 
Estas piezas no pueden considerarse bocados ni elementos de bocado, y no deben confundirse con las grandes anillas de los bocados del Tipo 2 de Argente, Díaz y Bescós (Fig. 8 ), ya que son mucho más finas, en bronce y abiertas. Son más bien narigones, utilizados para llevar el caballo de un ronzal, quizá en combinación con una jáquima. Un trabajo póstumo de la Prof. Lucas Pellicer (2004) insiste en esta cuestión, coincidiendo en el empleo de estas piezas, aunque proponiendo su compatibilidad con riendas y por tanto su ocasional empleo en el tiro (ibidem p. 107 y n.).

Un último elemento de control de la cabeza del caballo que es necesario recordar son los bozales metálicos (Fig. 4) que ocasionalmente aparecen en la Península Ibérica. Rara vez se conoce un contexto arqueológico (por ejemplo el caso ilustrado de La Pedrera, Garcés 2002), que apunta a un periodo prerromano y de cierta antigüedad. Se conocen algunos otros ejemplares en estudio, uno de la zona de Lorca en Murcia (por F. Quesada) y otro catalán (I. Garcés, com. pers.), además de algunos otros publicados pero no realmente estudiados, como el de Sangüesa (Navarra) (García Bellido, 1993) y otros de procedencia desconocida (Schüle 1969:Lám. 181.3). Estos bozales tienen paralelos desde el s. IV y antes en Grecia, en Beocia (Schüle 1969:126; Anderson 1961:Lám. 36 a) pero también hay una evolución en época romana (Taylor, 1975:129 ss.; Lawson 1978:140 ss.; Junkelmann 1992:33) de tipos ya diferentes pero claramente relacionados.

\section{ESPUELAS.}

\section{Generalidades. Espuelas griegas, celtas y romanas.}

La falta de una silla de montar propiamente dicha entre los pueblos de la Edad del Hierro hasta el s. I a.C. (v. infra) dejaba a los jinetes sin mayor sujección a la montura que la fuerza de las piernas y una postura adecuada, lo que aconsejaba tanto un sistema de bocado severo, como el estímulo de una espuela para mandar con energía al caballo en circunstancias apuradas ${ }^{14}$, ayuda esta última que sin ser esencial podía ser útil, en especial con brutos de cierto carácter.

Las primeras espuelas conocidas en Europa y el Mediterráneo no parecen remontarse a un momento anterior al s. $\mathrm{V}$ a.C. Todas ellas constan de un cuerpo metálico al que se enganchaban unas correas de sujección al tobillo. El cuerpo metálico consta de un soporte de bronce o hierro en cuya parte central se remachaba un aguijón o acicate también de bronce o hierro, o parcialmente de bronce rematado en punta de hierro. Hasta donde sabemos, no existe una tipología global de espuelas de la Edad del Hierro que tenga en cuenta las numerosísimas variantes, sobre todo dado lo amplio del ámbito geográfico y cronológico en que aparecen. Shortt (1959) y luego Dixon y Southern (1992:58-59) han empleado como criterio tipológico básico el sistema por el que se fijaba la correa de sujección al tobillo a la parte metálica de la espuela. Pueden distinguirse tres grandes series (Fig. 29). En la primera, poco común, se sujeta la correa mediante ganchos en el extremo del cuerpo doblado. En la segunda, mediante ranuras o ventanas relativamente amplias para lazadas; finalmente, en la tercera serie la correa se engancha a la espuela mediante botones o tachones discoidales, al principio solidarios al cuerpo de la espuela (en época de La Tène) y luego remachados al cuerpo (en el Imperio Romano); cuando se han perdido los botones remachados, dejan un pequeño orificio que no debe confundirse con la ventana del tipo anterior. En las espuelas tardorromanas, en todas las series la sujección puede venir reforzada con un gancho vertical en el cuerpo, sobre el acicate (Fig.30).

14 Por ejemplo, cuando el aqueo Filopemen se enfrentó con el espartano Machanidas en Mantinea en el 207 a.C. El caballo del tirano espartano saltó al notar en sus costados las espuelas ensangrentadas (Polibio 11, 18, 4; Plutarco, Filopoemen 10$)$. Jenofonte previene especialmente sobre el uso exagerado o indebido de las espuelas $(E q .10,1-2)$. 
En realidad, y aunque no sea un tema muy estudiado hasta el periodo romano, ${ }^{15}$ parece que en Grecia las primeras espuelas se remontan a mediados del s. V a.C. o antes, ya que el lexicógrafo Pollux (fl. s. II d.C.) cita $(10,53-54)$ a dos poetas cómicos atenienses de c. 430 a.C., Ferecrates y Crates, en torno a 'aguijones en los pies' y 'látigos en el talón' que sólo pueden referirse a espuelas (Anderson, 1961:87). Jenofonte (fl. c. 400) menciona el tábano o espuela $(\mu \cup \omega \psi)$ en su tratado sobre equitación $(E q .8 .5 ; 10,1.2)^{16}$ sin que parezca considerarla una novedad. Teofrasto (c. 372-287 a.C.) (Char. 21) se mofaba a mediados del s. IV a.C. de quien se pavonea por el Agora con las espuelas calzadas. Las piezas conocidas a menudo están mal datadas, pero pertenecen a los grupos descritos (Vigneron, 1968:Planche 31.a, b).

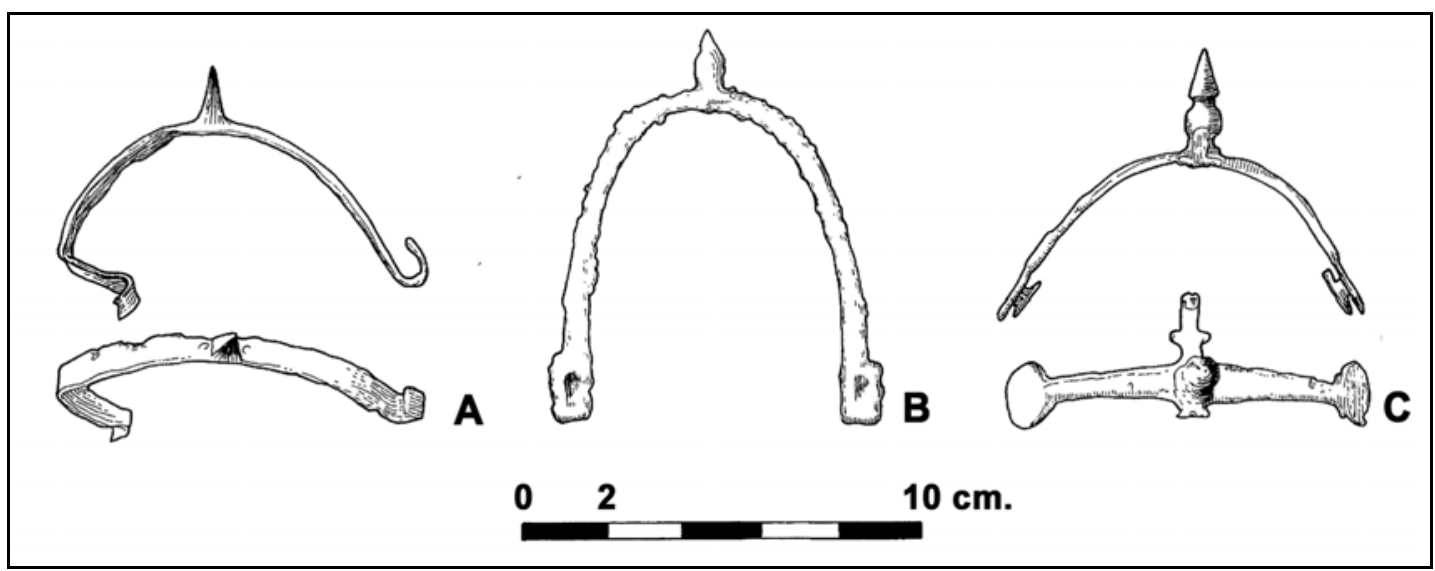

Fig. 29. Principales series de espuelas romanas. A.- De gancho. B. De lazada (o fenestrada) C. De remache. De Dixon y Southern (1992:Fig. 26, modificado de Shortt 1959).

En el ámbito celta se conocen espuelas prerromanas, pero ninguna como recuerda Anderson (1961:87), anterior al s. V a.C. (Dechelette 1927:708 ss.). Aunque se conocen modelos fenestrados, son más frecuentes las espuelas de bronce con botones discoidales para las correas fundidos en los extremos del corto cuerpo (Dechelette 1927:Fig. 514) (Fig. 31). Este tipo celta fue evidentemente el modelo para los posteriores tipos romanos, frecuentes en yacimientos de época alto- y bajoimperial en Britannia, Galia y Germania (Shortt, 1959, 1962; Bockius 1991). En la zona de Eslovenia se conocen sin embargo algunas espuelas fechadas en fases muy antiguas, quizá incluso en el s. V a.C., en facies Hallstaticas (Fig. 32), que, con sus ventanas y un cuerpo broncíneo con forma de tres discos unidos por láminas rectas, han sido considerados por Bockius (1991:Fig. 6, pp. 511-512) paralelizables a piezas numantinas e ibéricas prerromanas, y por tanto prototipos de otros modelos romanos de espuelas de tres discos con remaches de botón. En consecuencia, el cuadro es todavía confuso a nivel global.

$15 \mathrm{Y}$ en realidad ni siquiera entonces. Basta observar lo poco o nada que tienen que decir sobre espuelas los manuales modernos estándar sobre armamento y equipo militar romano (Bishop y Coulston, 1993; Feugère, 1993) o incluso otros específicos sobre equipo de caballería (Stephenson, Dixon, 2003). El trabajo clásico es el de M. Jahn (1921), al que complementa sobre todo Shortt (1959) y recientemente Bockius (1991).

16 «Despues de que, así, se acostumbre a pasar saltando, llévelo, primero, por cuestas poco pronunciadas y, luego, de mayor importancia, y cuando vaya a saltar, golpéelo con la espuela. Igualmente, ensénelo a saltar en cuestas y en pendientes arreándolo con la espuela»(8,5); «Si se quiere utilizar un caballo apto para la guerra y cabalgar como si fuera uno magnífico y famoso, debe evitarse tirar de su boca con el freno, picarlo con la espuela y arrearlo con el látigo, cosas que hacen muchos creyendo que resulta vistoso; el resultado es todo lo contrario de lo que ellos pretenden, ya que, al tirar de la boca hacia arriba, en lugar de que los caballos vean los que tienen delante, los ciegan, y, espoleándolos y pegándoles, los asustan, de modo que quedan turbados y corren peligro» (10,1-2). (trad. Orlando Guntiñas, BCG). 


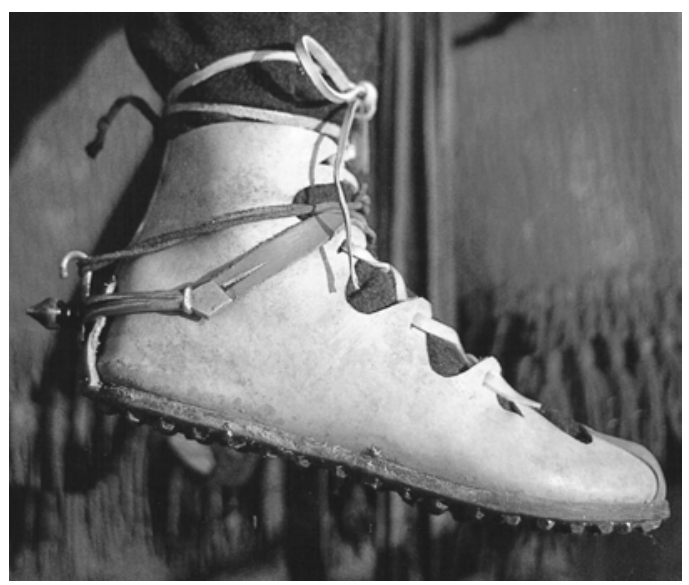

Fig. 30. Reconstrucción de una bota de caballería y espuela tardorromana del tipo Nietknopfsporn. Aunque se trata de un modelo evolucionado en el que el cuerpo se complementa con un gancho vertical para asegurar mejor la pieza al tobillo, el principio básico es el mismo de las espuelas seis siglos anteriores. De Junkelmann (1992:Abb. 53). Los botones o tachones de la espuela no se insertan en un ojal de la bota misma, como pensaba Vigneron (1968:85).

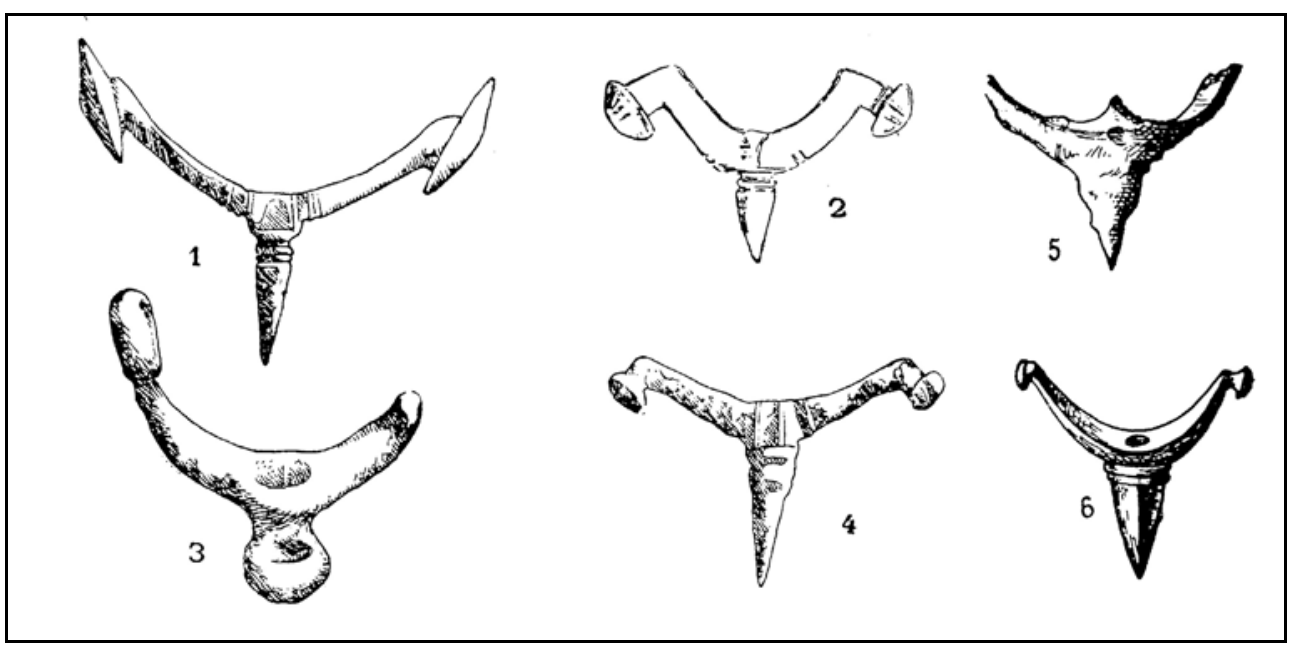

Fig. 31. Espuelas celtas prerromanas en bronce del grupo C, con botones o remaches en los extremos del cuerpo (de Dechelette 1927, Fig. 514).

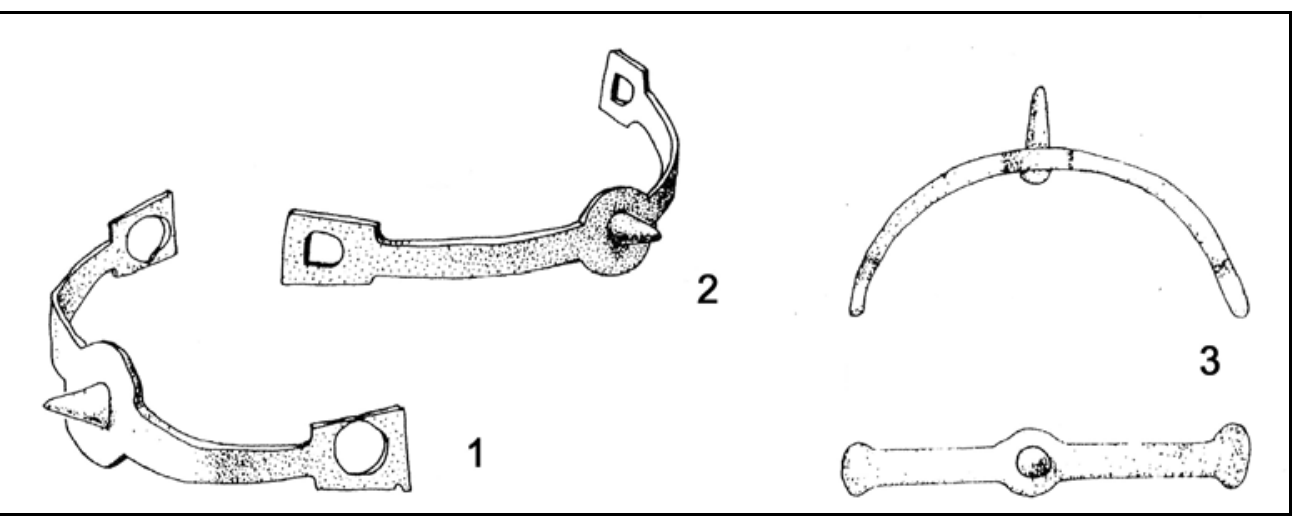

Fig. 32. Espuelas arcaicas prototipo del tipo tardocelta y romano altoimperial de tres discos. 1-2 Italia, procedencia desconocida. 3 Brezje, Eslovenia, Sep. 49 (según Bockius 1991). 
El mundo romano utilizó la espuela (calcar, -aris), aunque existe cierto grado de desacuerdo sobre el grado en que estuvieron generalizadas. Mientras que Vigneron (1968:84) consideraba que eran de uso común, basándose entre otras cosas en su empleo por literatos en contextos cotidianos, Shortt (1959:61) sostiene que - al menos en Britannia - no estaban generalizadas. Siguiendo la vieja clasificación de 1921 de M. Jahn, la mayoría de los tipos romanos imperiales derivarían de los primitivos modelos de La Tène, aunque recientemente Bockius (1991) ha llamado la atención sobre espuelas procedentes de Iberia, Italia y Grecia como precedentes de los tipos altoimperiales primitivos.

Dixon y Southern (1992:59) apuntan que las representaciones de espuelas son escasas en relieves y esculturas, aunque también recuerdan que en muchos casos pudo omitirse su representación debido a su pequeño tamaño, o que pudieron estar pintadas en lugar de talladas. Las fuentes literarias, por otro lado, aluden a las espuelas con naturalidad. ${ }^{17}$ Por cierto que Apsirto (fl. c. 300 d.C.) lista una serie de razas de caballos en su tratado sobre caza, y sobre los caballos hispanos comenta entre otras cosas que toleran mal la espuela ${ }^{18}$; hasta qué punto es un topos o sus versos tienen base real está abierto a especulación.

\section{Espuelas de la península Ibérica.}

Son hasta ahora escasos los estudios sobre este tipo de objetos en la Península Ibérica. Aunque eran identificadas desde momentos muy tempranos de los estudios ibéricos, dada su forma característica, como en tantas otras especialidades fue E. Cuadrado quien por vez primera realizó un estudio, partiendo un estudio de las espuelas ibéricas del Cigarralejo en Murcia (Cuadrado 1979). Cuadrado distinguió entre las espuelas de cuerpo rígido en forma de placa curva con acicate de bronce o hierro (su tipo I), y un tipo totalmente nuevo de espuelas articuladas muy complejas (su tipo II) (Fig. 33). Ambos tipos son coetáneos en el Cigarralejo, fechándose desde principios del s. IV a.C., fecha que sigue siendo una de las más antiguas conocidas para este tipo de objetos en Iberia. Posteriormente, Pérez Mínguez (1992) propuso una clasificación similar: el tipo I correspondería a espuelas de placa plana y ancha con orificio para las correas (Ia, orificio en la placa; Ib a modo de asa soldada a la placa), el II a espuelas donde el cuerpo no es una placa plana, sino una barra de sección redondeada o trapezoidal ('rama'), y el III a las articuladas (=II de Cuadrado). Por último, el excelente estudio de García Cano (1997) que es mucho más que el análisis de una necrópolis, realiza un breve catálogo de bastantes espuelas ibéricas, publicadas, pero no entra en cuestiones tipológicas de detalle. Fuera de estos trabajos, no existen análisis de cierta profundidad sobre las espuelas en Iberia, salvo la constatación de su existencia en diversas Memorias de Excavación y otros trabajos de catalogación de materiales (en último lugar, Quesada 2002-2003b).

De las tres series de espuelas que según hemos visto son habituales en el mundo celta y romano (Fig. 29), hasta ahora parece que sólo la B, esto es, las espuelas en las que la correa pasa por una ranura o ventanita en el cuerpo, fue empleada habitualmente en época ibérica. ${ }^{19}$

17 Así, Livio 2,6,8; 4,19,4; 8.30,6; 35,11,10 (siempre frases hechas en la descripción de un duelo). Tampoco son más explícitos César (Bell. Gal. 8,48) o Q. Curcio (3,13,8, 7,2,6). Literatos como Seneca (Ep. 68), Ovidio (Am. 785 ss.), Virgilio (Aen. 6, 881) Cicerón, Plauto y otros emplean expresiones más o menos pintorescas ern las que la espuela juega un papel.

18 Corpus Hippiatricorum Graecorum I, 372 ss. (Cf. Anderson 1961:22). Otras traducciones en cambio, se limitan a indicar que son «sans force pour l'équitation» ( $c f$. Menard, 2001:54).

19 Hemos tenido ocasión de observar en varios museos que espuelas de tipo romano imperial o tardorromano, pertenecientes a las series A y C de nuestra Figura 29, e incluso de tipos a nuestro juicio ya medievales, aparecen en vitrinas asignadas a la Cultura Ibérica. Cuando hemos podido indagar en detalle, estas espuelas carecen de contexto arqueológico preciso, o proceden de hallazgos de superficie en yacimientos de amplio espectro cronológico. Conviene ser pues 
Es también posible que existieran algunas espuelas de serie $\mathrm{C}$, con botón remachado, pero no solidario. Las espuelas con gancho (Fig. 29.A) o botón solidario (Fig. 29.B) en los extremos del cuerpo son características del mundo celta (Dechelette 1927) y del romano desde el s. I d.C. en adelante (Shortt 1964:60) y no aparecen, hasta donde nosotros sabemos, en contextos claros ibéricos o celtibéricos prerromanos, o del periodo republicano de la conquista. Por otro lado, en conjunto las espuelas peninsulares aparecen mucho menos decoradas que las célticas o las romanas, que a menudo rematan en cabezas de animales (Shortt 1959, $\mathrm{n}^{\circ}$ 19) o se decoran recargadamente (Shortt, $1959 \mathrm{n}^{\circ} .17$ ).

Provisionalmente, nosotros hemos distinguido (Quesada 2001-2002; 2002-2003b:87) seis Grupos diferentes de espuelas prerromanas o de época de la conquista, muy diferentes en cuanto a frecuencia. Dentro de esos grupos hemos definido una serie de Tipos designados por letras. Su definición es como sigue:

Grupo 1 (Fig. 33): Incluye las espuelas articuladas del tipo II de Cuadrado (1979) y III de Pérez Mínguez (1992). Se conocen sólo cinco ejemplares, y todos ellos pertenecen a un solo Tipo, el tipo 1A, procedentes de Murcia (Cigarralejo x2, Coimbra del Barranco Ancho), Baza (Granada) y Serreta de Alcoi (Alicante) (Quesada 2001-2002, 2002-2003b:95); son por tanto un grupo muy minoritario, en una proporción conocida del orden de una a veinticinco.

Los ejemplares murcianos están bien datados en una horquilla que no va más allá del 375-325 a.C. Esta fecha encaja perfectamente con la cronología general de la necrópolis del Cerro del Santuario de Baza (datación general del s. IV, con una concentración máxima entre el 375-325 a.C.), de donde procede seguramente la única espuela con contexto impreciso, y que casualmente es con diferencia la mejor conservada.

Tipológicamente el rasgo más llamativo de estas piezas es su extrema complejidad. Pensemos que para un objeto de unos $15 \mathrm{~cm}$. de longitud total y $1.5 \mathrm{~cm}$. de altura se han unido entre sí un total de treinta y seis piezas (Quesada 2001-2002). Si tenemos en cuenta que los iberos conocían de sobra un tipo de espuela mucho más sencillo (dos o a lo sumo tres piezas), igualmente eficaz, probablemente más sólido y perteneciente a un grupo tipológico extendido por todo el Mediterráneo y Europa, lo que atestigua su eficacia, resulta verdaderamente chocante la existencia de estas espuelas articuladas para las que hasta ahora no conocemos paralelos fuera de Iberia. La Cultura Ibérica no se caracteriza precisamente por una sofisticación extrema en la elaboración de sus armas y arreos de caballo, aunque en el campo de la decoración hay verdaderas obras de orfebrería. Sin embargo, estas espuelas parecen piezas del mayor lujo, elementos de distinción aristocrática. Siempre que tenemos contexto para ellas aparecen en tumbas de rango 'principesco'. Técnicamente se trata de piezas excelentemente realizadas y, a pesar de su apariencia, no especialmente frágiles.

Las espuelas articuladas aparecen siempre por unidades; las rígidas pueden aparecer sueltas o por parejas. Esto es normal, y ocurre en otras culturas, por ejemplo en el mundo griego clásico. Anderson (1961, p. 87) sugiere que se llevaban en el tobillo izquierdo, de manera que el caballo se guiaba con una espuela en el costado izquierdo y una vara o fusta en la mano derecha. Pero dice añade el autor que «two spurs would be less likely to make the horse run off to one side, and were no doubt usual by Teophrastus's time» (Anderson, 1961, p. 87).

Por último, conviene hacer una reflexión breve sobre la dispersión geográfica conocida hasta ahora de estas espuelas. La gran semejanza entre las piezas de Jumilla y Mula no había llamado hasta ahora demasiado la atención, dado que son bien conocidas las grandes similitudes en la cultura material, rito y estructura entre las necrópolis de ambas comarcas, semejanzas que se manifiestan además en otros arreos de caballo, como entre la frontalera de cobre forrada en plata de la Sep. 200 del Cigarralejo (Cuadrado, 1987, 365, Fig. 151) y la casi

cuidadoso en la atribución cronológica de estos pequeños objetos hasta que se pueda demostrar que estas series también se emplearon entre Iberos o Celtíberos, lo que en el caso de las formas tardías del Grupo C parece harto improbable, y dudoso en el de la Serie A. 
idéntica pero férrea de la Sep. 55 de la necrópolis del Poblado en Coimbra (García Cano, 1997, Fig. 111). Pero la aparición de una espuela articulada en Baza, y tan próxima en dimensiones y estructura al menos a la de Cigarralejo 277 como para pensar en una fabricación por parte del mismo taller o artesano, nos permite proponer una vía de contacto bastante directa entre Baza-Galera y el Segura vía Huescar, Almaciles y Caravaca (Quesada, Martínez, 1995; Quesada, 2001-2002). Este pequeño pero muy significativo elemento asociado a las elites ecuestres que es la espuela articulada parece venir a reforzar la hipótesis de un estrecho contacto entre ambas regiones en torno a mediados del s. IV a.C.
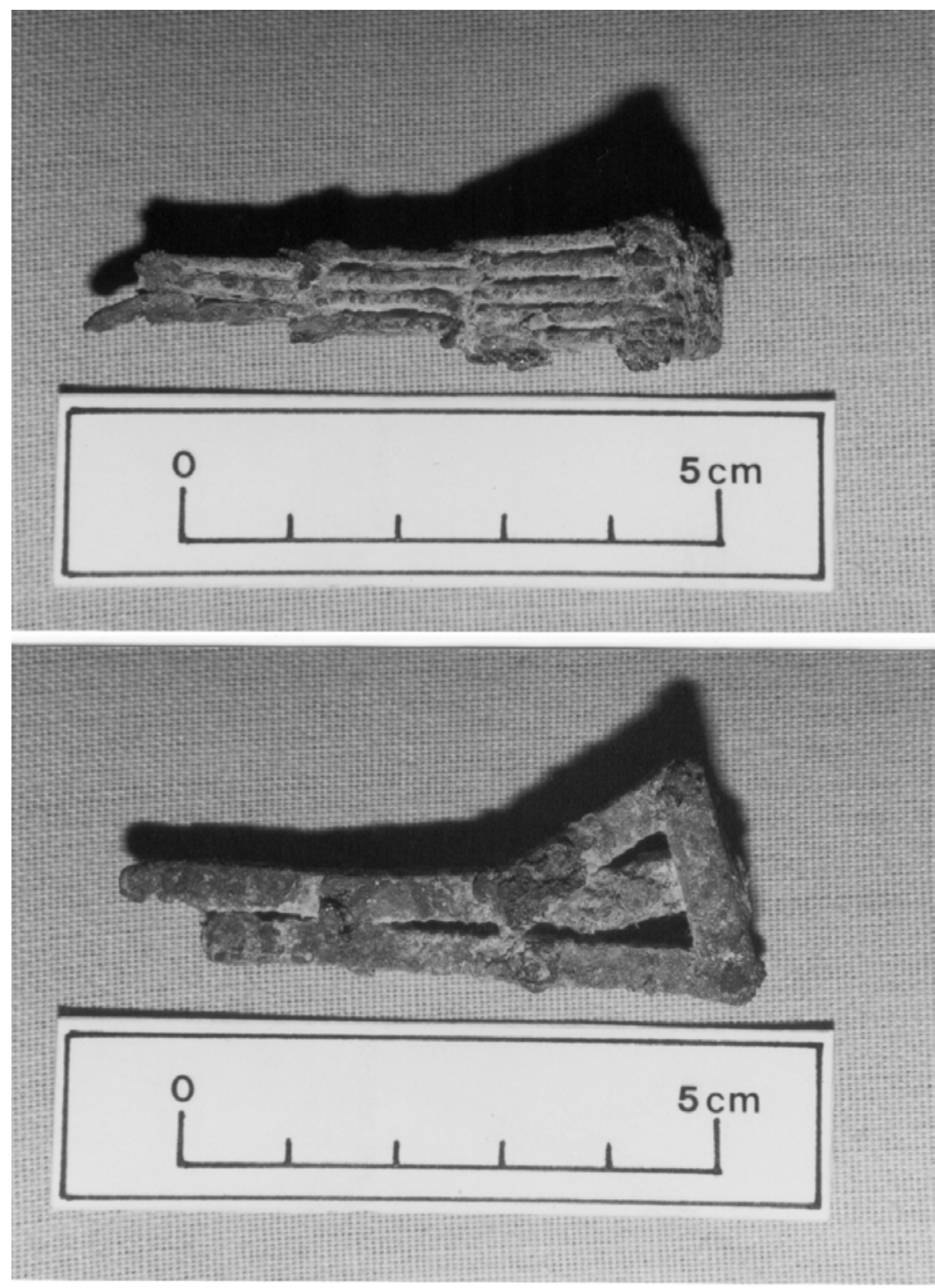

Fig. 33. Espuela articulada de Grupo Quesada 1 (=Tipo Cuadrado II). Según Quesada (2001-2002). Los brazos articulados están doblados hacia afuera, envolviendo el aguijón. Pieza procedente de Baza (Granada). 
Grupo 2 (Fig. 34): Está formado por espuelas de cuerpo rígido en bronce o hierro formado por una placa plana y bastante ancha, normalmente de entre 2 y $3 \mathrm{~cm}$. Es, junto con el Grupo 3, el más frecuente en Iberia, y el más típicamente peninsular. Incluye espuelas de placa rectangular sencilla - tipo $2 \mathrm{~A}$ - que, con una quincena de ejemplares, es el tipo más frecuente del grupo, y el segundo más habitual en la Península. El tipo 2B lo forman espuelas de placa rectangular con un resalte o moldura en las parte superior o inferior. El $2 \mathrm{C}$ incluye las espuelas de mayor tamaño de las conocidas, con grandes placas rectangulares, molduradas y rematadas en pequeñas asas que sustituyen las ventanas o ranuras de los demás tipos. Sus acicates son además de gran tamaño. El tipo 2D agrupa las espuelas de placa rectangular con varias molduras o estrías horizontales en el cuerpo; algunas son piezas estrechas, más tiras alargadas que placas rectangulares (y por tanto podrían clasificarse en el Grupo 3), pero su homogeneidad con el resto hace que las hayamos agrupado. El tipo 2E está dedicado a las piezas con placa de forma oval en lugar de rectangular; el $2 \mathrm{~F}$ las placas estranguladas en la zona central, donde arranca el acicate. Finalmente, el tipo 2G incluye las espuelas formadas por dos pequeñas placas soldadas.

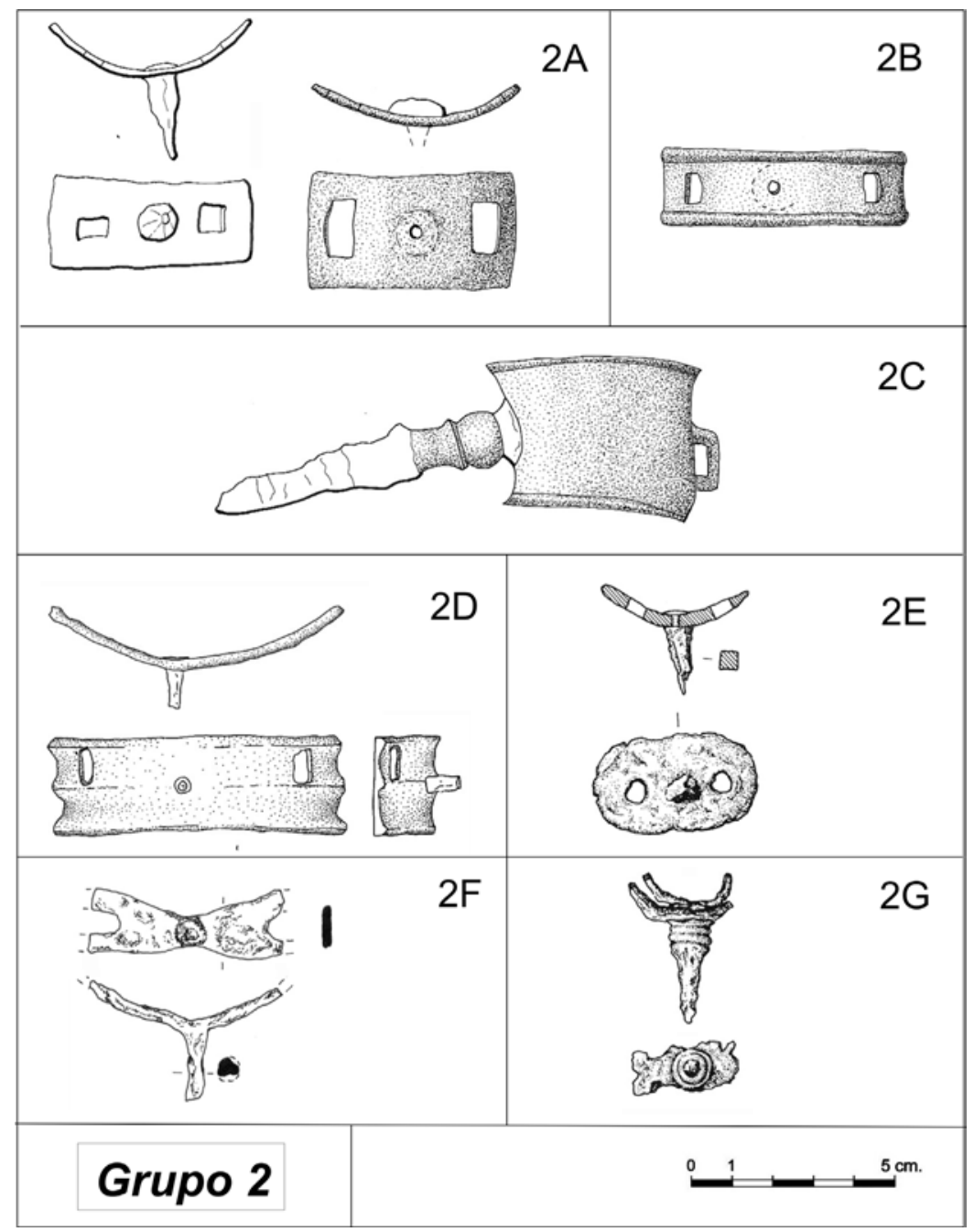

Fig. 34. Tabla del Grupo 2 de espuelas de la Península Ibérica. 
Grupo 3 (Fig. 35): Está constituido por espuelas formadas por un cuerpo rígido en bronce o hierro en forma de tira o placa plana y estrecha, en torno a $1 \mathrm{~cm}$. Similar al Grupo 2 pero con piezas mucho más estrechas.

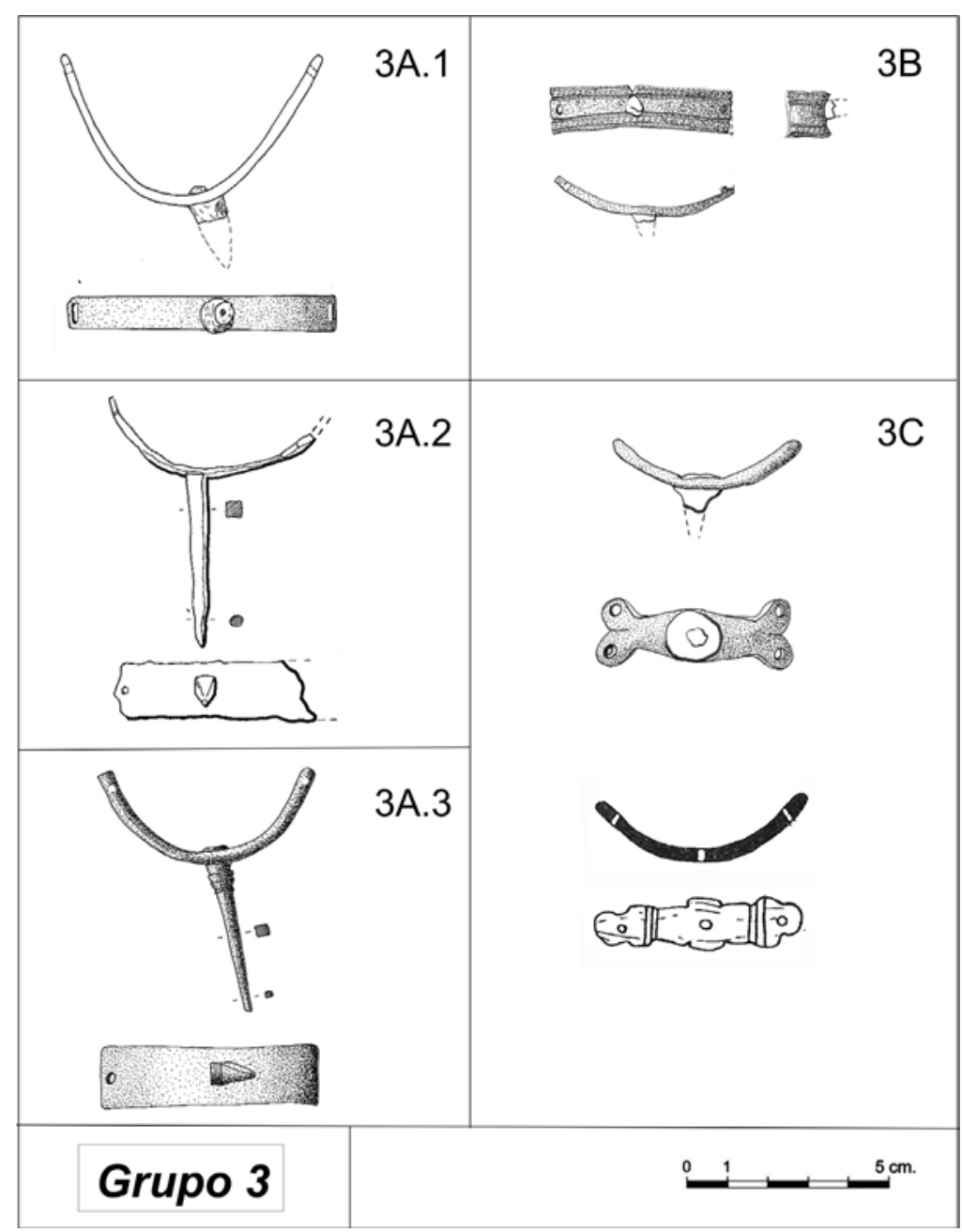

Fig. 35. Tabla del Grupo 3 de espuelas de la Península Ibérica.

El tipo 3A, con cerca de una veintena de ejemplares, es el más frecuente. Se forma con espuelas de tira estrecha y plana con ventana para la correa de sujección al tobillo (3A.1). El subtipo (3A.2) está formado por piezas que en lugar de ventana tienen un pequeño orificio que pudo servir no para sujetar directamente las correas, sino pare remachar un botón o tachón al que se sujetarían las correas mediante un ojal, en un sistema típicamente romano y celta. Este sistema de orificio pequeño no se da nunca en las espuelas más anchas y grandes del tipo 2A, que siempre cuentan con una ventana rectangular o circular bastante grande. Finalmente, el subtipo 3A.3 es idéntico al anterior, pero con la particularidad de que junto al habitual orificio horizontal en los extremos del cuerpo, éste presenta además dos perforaciones verticales para pasar una anilla móvil, sistema alternativo de sujección. Sólo conocemos una pieza con este doble sistema, procedente del poblado de La Serreta de Alcoi. 
El tipo 3B está formado por unas pocas espuelas de cuerpo pequeño en forma de tira de bronce decorado con motivos incisos y repujados, con orificios para probables remaches y botones. El tipo 3C incluye igualmente escasas piezas con la tira metálica no rectangular, sino rematada en lóbulos con pequeños orificios.

Grupo 4: Recoge espuelas cuyo cuerpo no es ni una placa ni una tira plana de metal, sino una barra estrecha de sección más o menos trapezoidal o semicircular, cuya anchura máxima no llega al centímetro; el acicate, además, suele ser muy corto. Incluye varios tipos diferentes: con orificios horizontales y cuerpo rematado de diversos modos (4A.1, 4A.2, 4A.3); con orificio diagonal (4B), con extremos serpentiformes (4C). El Grupo 5 está formado por espuelas similares a las del Grupo 4 pero con orificios verticales para sujetar anillas móviles (Tipo 5A). En conjunto ambos grupos parecen bastante tardíos.

Finalmente, el Grupo 6 recoge una serie de tipos bastante heterogéneos cuyo rasgo común es su cronología tardía o muy tardía (de fines del s. II al cambio de Era) y corresponder a tipos romanos o celtas documentados en otros puntos como Galia, Italia o Mediterráneo Oriental, y que no deben ser considerados como tipos 'locales', aunque hayan podido ser fabricados en Hispania. Un problema es ciertamente distinguir espuelas indígenas de las romanas en contextos de los siglos II-I a.C. al que pertenecen muchas de ellas. Los hallazgos de los campamentos numantinos (Schulten, 1927, pl. 35) y de Cáceres el Viejo (Ulbert 1984), con tipos en los que el cuerpo es una placa plana de bronce con orificios, están en la más pura tradición indígena, pero bien pueden — deben - haber sido empleados por las tropas romanas, en especial las unidades de caballería auxiliar. Con todo, hay un tipo específico (denominado Kobarid por el Dr. Dragan Bozic a quiena agradecemos parte de la información que citamos) (Fig. 36) que parece fecharse consistentemente en la primera mitad del s. I a.C. con cierta oscilación en ambos sentidos y que, documentado en Hispania (Numancia, Fig. 36.1; Caminreal, Fig.36.2), aparece también en Kobarid (Eslovenia, Fig. 36.3), Corinto, Dodona, Olimpia, y Telamon, con lo que parece lógico adscribirlo a la esfera romana. En este sentido, las piezas ibéricas más sencillas de cuerpo de placa lisa contrastarían con estas espuelas romanas más elaboradas.

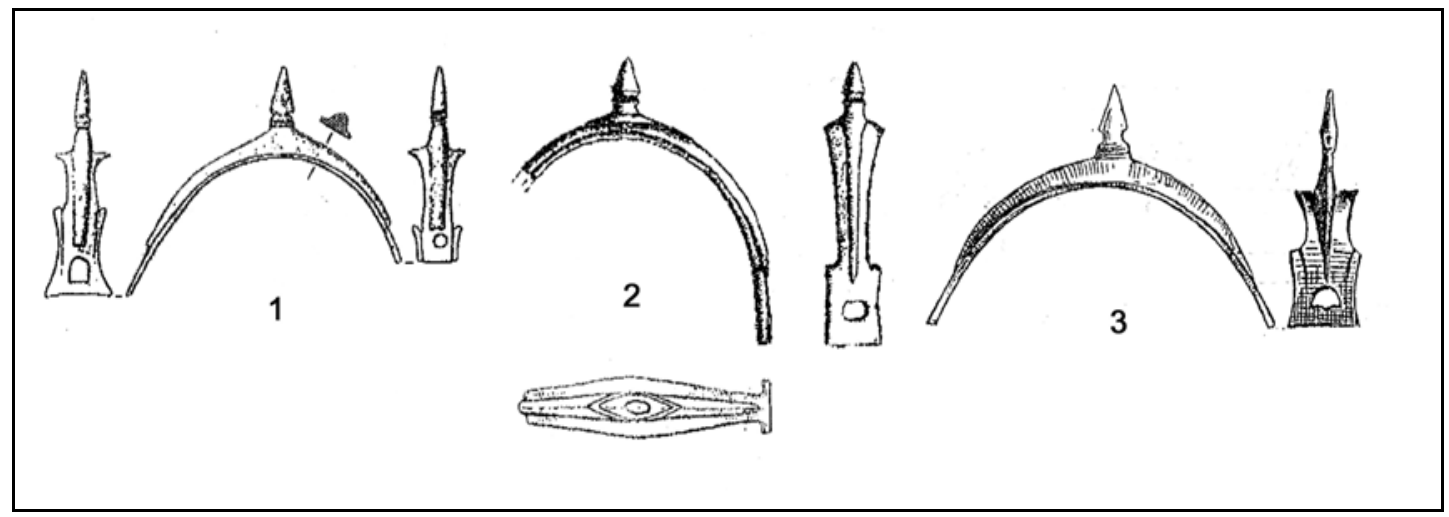

Fig. 36. Espuelas romanas republicanas del Grupo 6. 1 Numancia (Soria). 2. Camnireal (Teruel). 3. Kobarid (Eslovenia).

Por otra parte las espuelas son también bien conocidas de antiguo gracias a la iconografía: la cerámica decorada de S. Miguel de Lliria ha proporcionado numerosos detalles que muestran la existencia de estos elementos, normalmente atados a los dos tobillos (Ballester et alii 1954:110, motivos 385 a 393; Quesada, 2002-2003) (Fig.37). 


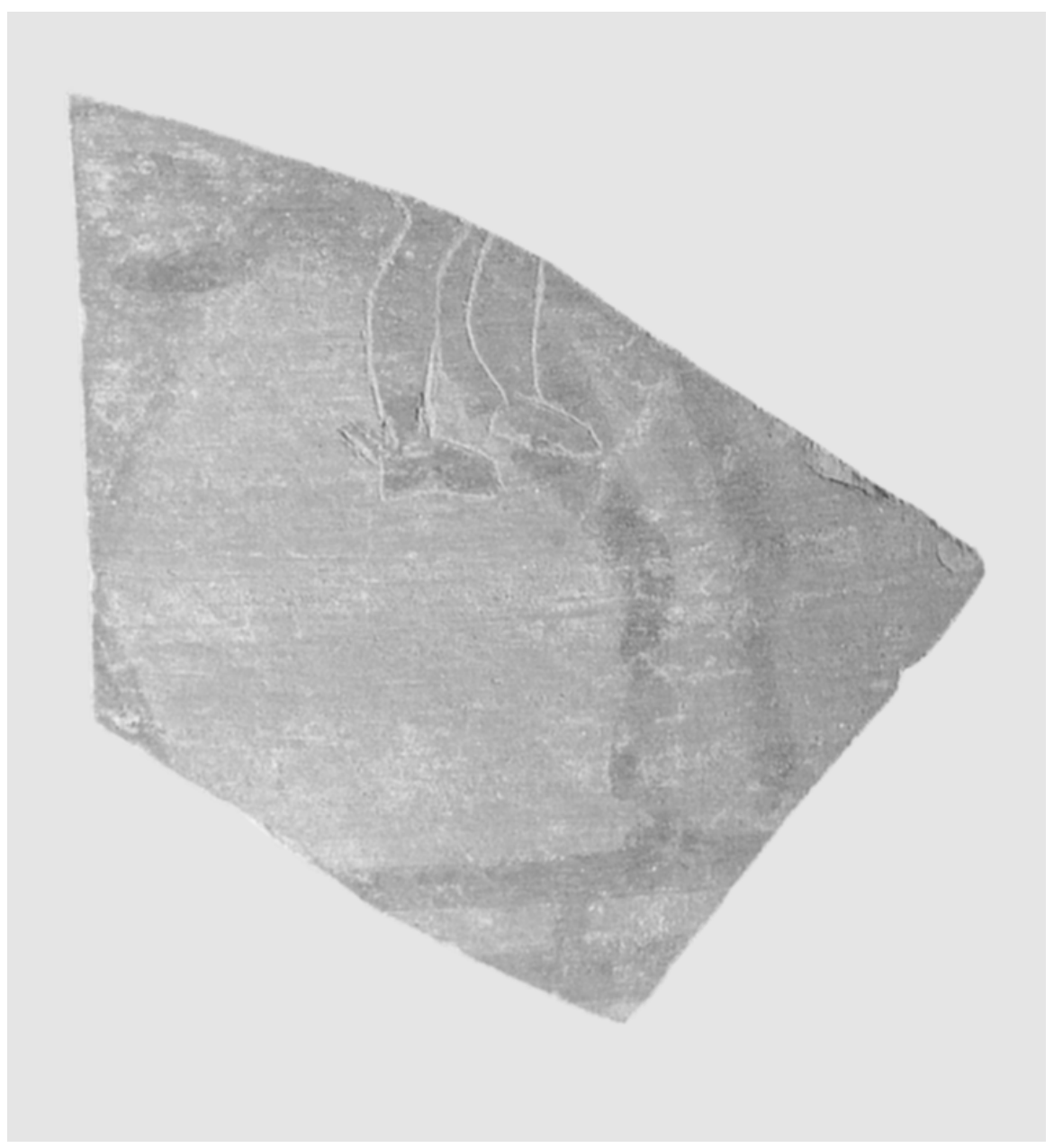

Fig. 37. Jinete ibérico con espuela en una cerámica pintada retocada por incisión. S. Miguel de Liria (Bonet 1995, Fig. 198, Lám. XXVI).

El conjunto de espuelas hispanas conocidas supera el centenar de ejemplares. Su dispersión no presenta sorpresas notables (Quesada 2002-2003b:87): reproduce basicamente la densidad y tipo de yacimientos conocidos; en ese sentido, reproduce los patrones de dispersión de, por ejemplo, las armas de la Edad del Hierro (Quesada 1997). El único rasgo verdaderamente llamativo es que conocemos con diferencia más espuelas en las regiones 'ibéricas' de Andalucía, Sureste y Levante que en las áreas del interior peninsular (32 yacimientos frente a 13). Si contabilizamos el número de piezas, vemos que el mundo 'ibérico' proporciona por ahora 71 espuelas (el 79\%) frente a sólo 19 (21\%) del ámbito 'celtibérico'. Esto es muy curioso porque, por el contrario, la gran mayoría del total de arreos de caballo (bocados, frontaleras, serretones, cabezadas metálicas, etc. excluyendo las espuelas) presenta una distribución geográfica inversa en un primer y todavía muy provisional recuento: 70 (32\%) en el mundo 'ibérico' frente a $146(68 \%)$ en el 'indoeuropeo'. Este fenómeno deberá ser estudiado más a fondo en el inmediato futuro. Por ahora se diría que las espuelas eran mucho más populares entre los Iberos que entre los Celtíberos; de todos modos, como el catálogo dista de ser exhaustivo, conviene todavía tomar esta tendencia con precaución. 


\section{LA SILLA DE MONTAR EN LA ANTIGÜEDAD CLÁSICA.}

\section{Generalidades}

La monta a pelo en línea recta es razonablemente sencilla para un buen jinete, que además puede abordar giros, saltos, etc. si puede concentrarse en la monta y no se encuentra estorbado por otros elementos. Pero en el caso de un jinete con armamento defensivo, incluso con escudo, con armas ofensivas (Fig. 38), y además hostigado por enemigos cuya intención es matarle, la situación es muy diferente, y cualquier ayuda que contrapese la subida del centro de gravedad que supone una coraza y la inestabilidad inherente al combate suele ser bienvenida (Hyland, 1990:130-131).

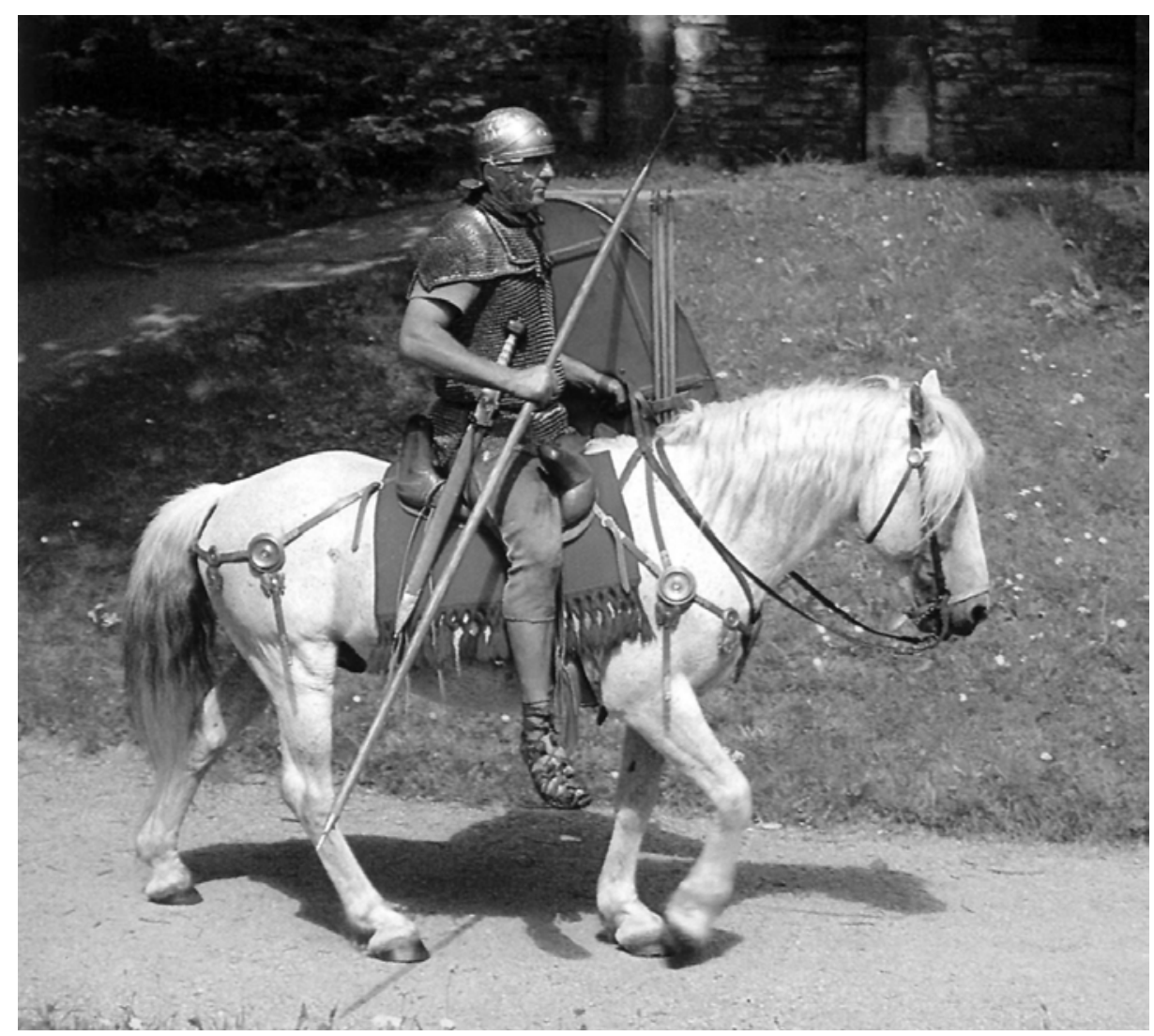

Fig. 38. Reconstrucción de un jinete romano completamente equipado en el s. I d.C. (Según Junkelmann 1992)

El mundo helénico — como el ibérico - no conoció la silla de montar. Los griegos emplearon el ephippion, una manta o gualdrapa, simple o doble, sujeta al caballo por una cincha (Gaebel, 2002:27, Anderson, 1961:79 ss.; Vigneron, 1968:82-83), sistema quizá de origen oriental adoptado por otros pueblos del Mediterráneo como los Iberos (Cuadrado, 1948, 1950). Jenofonte se mofa de los persas que emplean mantas demasiado acolchadas (Ciropedia, $8,8,19$ ), porque miran más por su comodidad que por la seguridad de la monta: 'En cambio, ahora tienen [los persas] más mantas sobre el caballo que sobre su cama, pues no 
se ocupan tanto de la forma de montar como de disponer de un asiento mullido' (trad. A. Vegas). En sus tratados sobre equitación, describe la caballería griega armada básicamente con jabalinas, aunque también recomienda un completo armamento defensivo y el uso de sables (kopides), de modo que admite el combate cuerpo a cuerpo desde el caballo, sin que la ausencia de silla o estribo parezca suponer una dificultad excepcional a la hora de descargar los golpes (De la Equitación, 12, 12); ver Gaebel (2002:91).

Los escitas de las estepas contaban desde el s. V a.C. con modelos primitivos de estructura de madera combinada con cojines, que difícilmente pueden ser consideradas 'sillas' en el sentido moderno del término (Anderson, 1961:81-82; Hyland, 2003:52). La silla propiamente dicha, con armazón de madera, parece haber sido un invento de los pueblos nómadas de Asia, aunque el momento preciso se debate.

En todo caso, de entre los pueblos mediterráneos fueron los celtas (quizá en el s. II a.C.) y luego los romanos (desde el s. I a.C.) quienes emplearon un modelo de silla arzonada que, incluso sin estribos, proporcionaba al jinete una estabilidad y seguridad mucho mayores en la monta, además de facilitar el manejo de las armas (Hyland, 1993:46-48), y que permitía que jinetes entrenados ya en su edad adulta — por oposición a los jinetes nómadas que prácticamente aprendían a montar al tiempo que a andar - pudieran manejarse con razonable eficacia ${ }^{20}$. Quizá por ello los germanos consideraron afeminada esta silla de montar (César, Bell. Gal. 4, 2, 2). Además, la silla cumplía la función adicional de transferir buena parte del peso del jinete de la columna vertebral hacia los flancos del caballo, para cansarle menos (Connolly, van Driel Murray, 1991:33).

La silla romana 'altoimperial' (Fig. 39) consta de un arzón de madera reforzado con piezas de bronce para cuatro pomos o perillas de metal (dos delanteros y dos traseros) en forma de cuernos romos que literalmente encajan al caballero. Los dos traseros, verticales, sujetan las nalgas, mientras que los delanteros, inclinados hacia los lados, encajan bajo ellos los muslos del jinete. Su forma general era conocida por relieves como el monumento de los Julios en St. Remy (Sur de Francia) (Connolly, van Driel-Murray, 1991), pero sólo el trabajo experimental llevado a cabo en los años ochenta por Peter Connolly, y el estudio detallado por parte de Carol van Driel Murray de las piezas de cuero conservadas en yacimientos británicos y holandeses (y en especial la de Valkenburg), que originalmente forraban las sillas de montar, ha permitido realizar reconstrucciones modernas fiables (Connolly, van DrielMurray, 1991). La silla se colocaba sobre una manta, y se aseguraba mediante cincha y petral (Connolly, 1986; 1989:62-63; Connolly, van Driel-Murray, 1991:33). La conclusión principal de los trabajos experimentales de P. Connolly es que se trataba de una verdadera silla con estructura interna de madera, y no sólo de un asiento acolchado al que se cosían los pomos de lámina de bronce (Connolly, van Driel-Murray, 1991:40). Sobre ella se aseguraban piezas acolchadas para proteger tanto a caballo como a jinete, y el conjunto se cubría con una serie de piezas de cuero cosidas entre sí y colocadas como una funda.

Esta interpretación contrasta con la opinión de Marcus Junkelmann, quien en sus propios experimentos favorece la idea de que la silla era una suerte de cojín acolchado forrado de cuero con una estructura frontal muy limitada, ya que Junkelmann concluye que la silla menos rígida y acolchada de su diseño cansa menos al jinete que la reconstrucción de Connolly cuando éste no lleva estribos (Junkelmann, 1992:105; Connolly, van Driel-Murray, 1991:4042). Esta solución sin embargo no cuadra bien con las marcas observadas en las fundas de cuero originales. Parece por otro lado que existieron dos tipos de silla, con perillas pequeñas y grandes. Algunas marcas en estas piezas han llevado a sugerir que las sillas se hacían a medida, pensando en caballos y jinetes concretos (Connolly, van Driel-Murray, 1991:47), lo que personalmente nos resulta difícil de creer desde un punto de vista logístico.

20 Aunque la caballería auxiliar romana procuraba reclutar hombres ya familiarizados con la monta desde la niñez, este no era el caso siempre, como recuerda Vegecio (ver Hyland, 1990:111 ss.). 


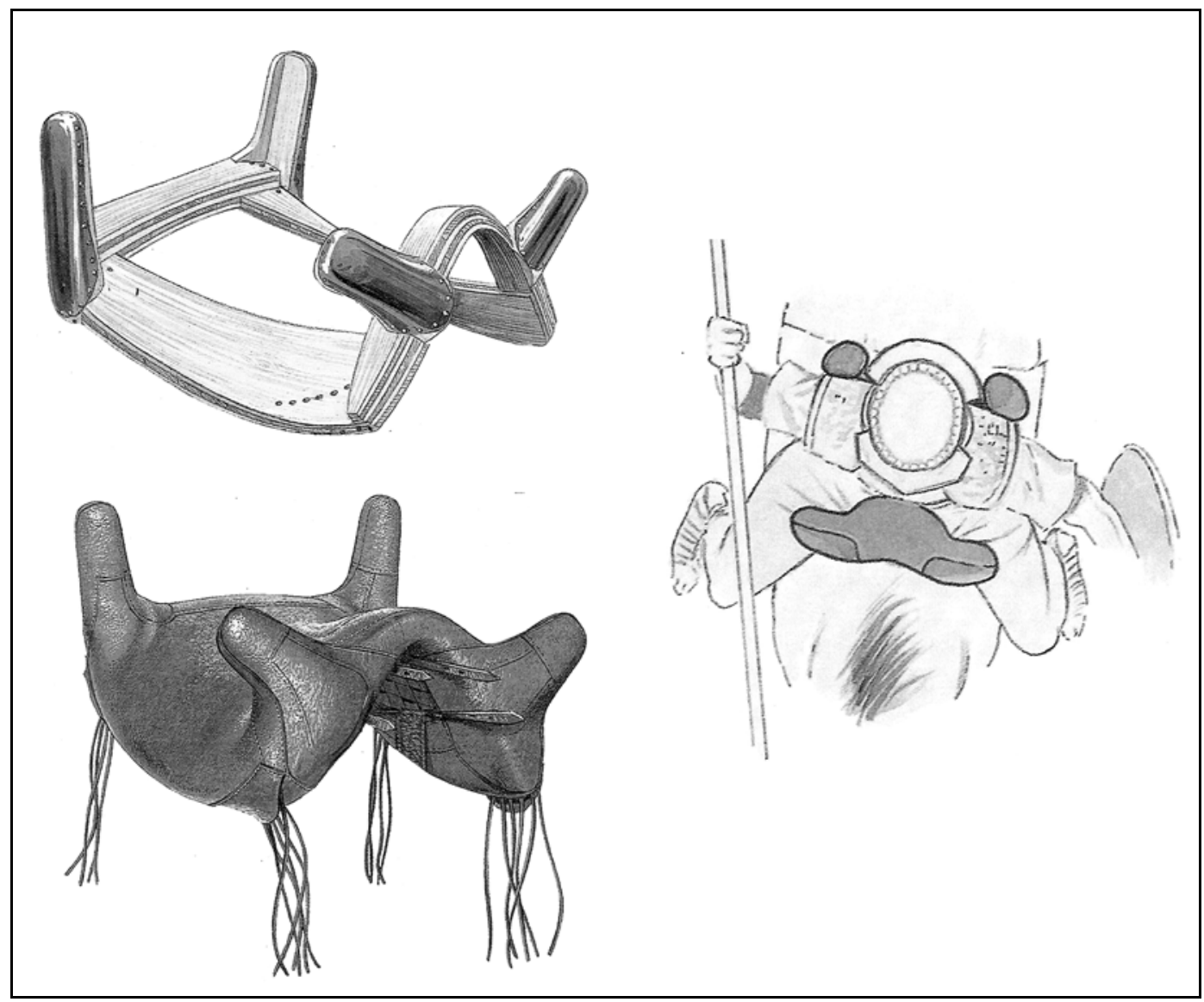

Fig. 39. Reconstrucción de una silla romana altoimperial con armazón de madera (según Connoly, 1989) y Quesada (2004b).

Las diferentes versiones reconstruidas han sido probadas con éxito por Ann Hyland (1990:134), M. Junkelmann (1992: 100ss.) y otros autores en caballos de escasa alzada, similares a los romanos. A. Hyland ha insistido en la similitud del modelo rígido de Connolly con algunas sillas de montar modernas destinadas a trabajar con ganado (American cutting horse saddle) (1990:134; 1993:45). Marcus Junkelmann ha probado experimentalmente que es la silla de cuernos, y no el estribo, lo que dota al jinete de una gran ventaja en el combate cuerpo a cuerpo (Junkelmann, 1992:110-111). Las pruebas efectuadas por Ann Hyland revelan que incluso un jinete no demasiado experto puede conseguir una sujección segura, y la tranquilidad necesaria para arrojar jabalinas o golpear con espada o lanza en la confianza de que no saldrá despedido con el choque o con cualquier eventual extraño que haga el bruto. Además, los pomos rígidos favorecen montar y desmontar sin estribo, apoyando el peso sobre las piezas delanteras. En conjunto, pues, la silla supuso una gran ventaja que proporcionó a la caballería, pesada y ligera, unas ventajas desconocidas en época clásica o helenística, aunque no revolucionó las tácticas.

Este modelo de silla 'de cuernos' no es, como se ha visto, exclusivamente romano. Copiado probablemente de los celtas (Goldsworthy 2003:139-140), fue también empleado en oriente por partos y sasánidas hasta el s. VI d.C.; en Roma fue empleado al menos hasta el s. 
V d.C., cuando fue desplazado por un modelo tomado de los Avaros de la estepa asiática (Stephenson, Dixon, 2003:110, Fig. 99) (Fig. 40).

En el caso de la Península Ibérica, incluso en la zona meseteña, no hay ninguna evidencia directa ni indirecta del uso de ningún tipo de silla de montar. Cuando la iconografía es precisa y de carácter genuinamente ibérico, es evidente que nos encontramos ante un ephippion a menudo doble (Fig. 41) como ya analizara perfectamente hace muchos años E. Cuadrado $(1948,1950)$. En otros casos, la iconografía tardía es de corte helenístico y muestra mantas de tipo helénico. Pero en ningún caso hay indicios de sillas arzonadas de tipo celta o romano, y en algunas representaciones en que parecen apreciarse resaltes en la parte trasera y delantera de la manta — por ejemplo en pequeñas terracotas (Quesada, Tortajada 1999:16, $\mathrm{n}^{\circ}$ 8) - se trata del propio ephippion y no de borrenes, o de piezas de cronología ya romana; en algún caso concreto una pieza que se ha considerado ibérica es claramente de época romana

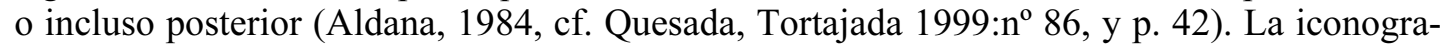
fía monumental, siempre más precisa que la toreútica o la coroplastia, es en este sentido decisiva para confirmar que los iberos montaban sobre manta acolchada, como se aprecia en el primer jinete de Los Villares, el caballo de Casas de Juan Nuñez — con manta griega - y otros muchos ( $c f$. Blech 2003:174).

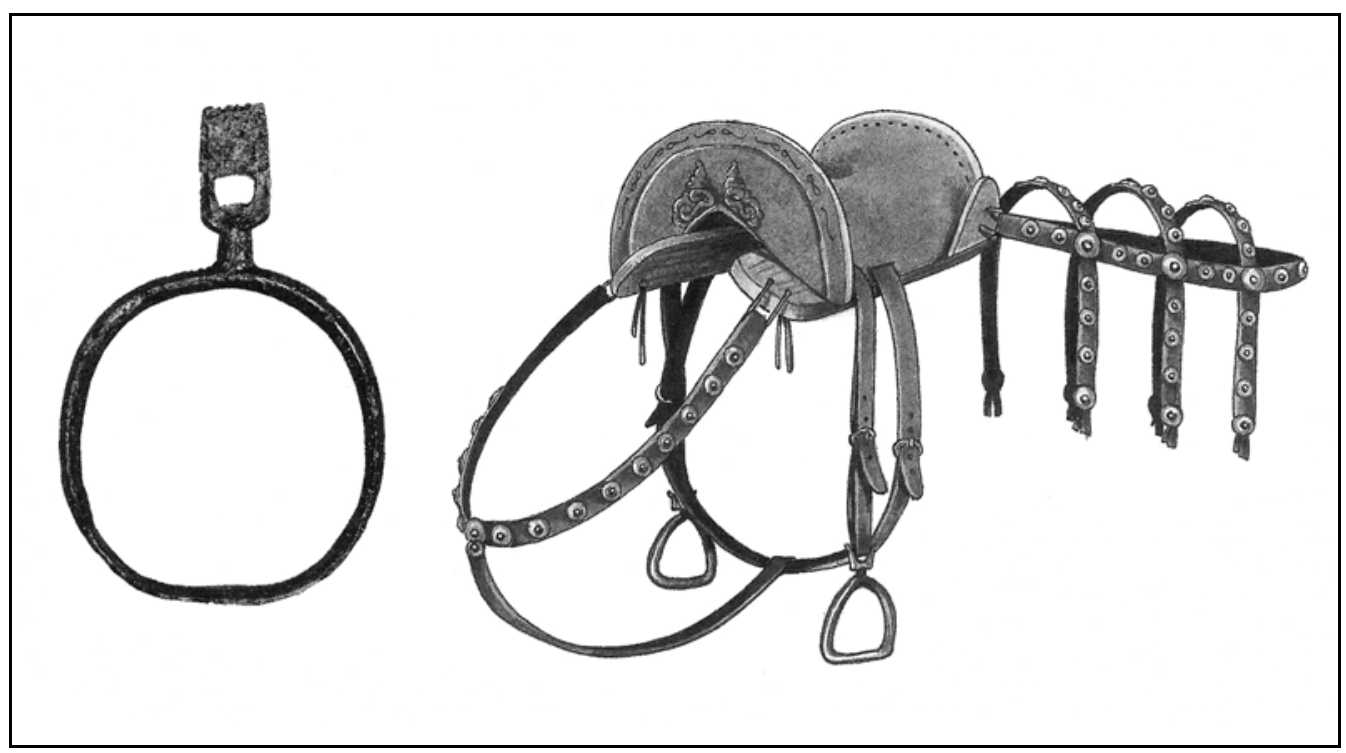

Fig. 40. Silla tardoantigua de los Avaros (a partir de Stephenson y Dickson 2003).

\section{LA AUSENCIA DEL ESTRIBO EN LA ANTIGÜEDAD Y SU INFLUENCIA EN LA MONTA.}

La cuestión de la introducción del estribo en Europa es más controvertida que la de la silla de montar. La mención más antigua del estribo (en griego, skala) en una fuente literaria occidental procede del Strategikon de Mauricio (libros 1.2 y 2.9), obra bizantina de tema militar escrita durante su reinado o más probablemente en el de su inmediato sucesor Focas, muy a principios del s. VII d.C. (Dennis, 2001). Por tanto, el estribo era conocido en Bizancio al menos desde las últimas décadas del s. VI d.C.

Es curioso que esta invención no se produjera en ningún pueblo del Mediterráneo, y que tardara tanto en llegar, dado que se conocen primitivos estribos en forma de lazada represen- 
tados en el Deccan (India) en el s. II a.C (Azzaroli 1985:156; Hyland, 2003:54), ${ }^{21}$ y China conocía formas más evolucionadas al menos a principios del s. IV d.C. (Hyland, 2003:54) y con plena seguridad en el s. V d.C. (Hyland, 1994:11; Azzaroli, 1985:157-159; White, 1962:15; Junkelmann, 1992:101) $)^{22}$.

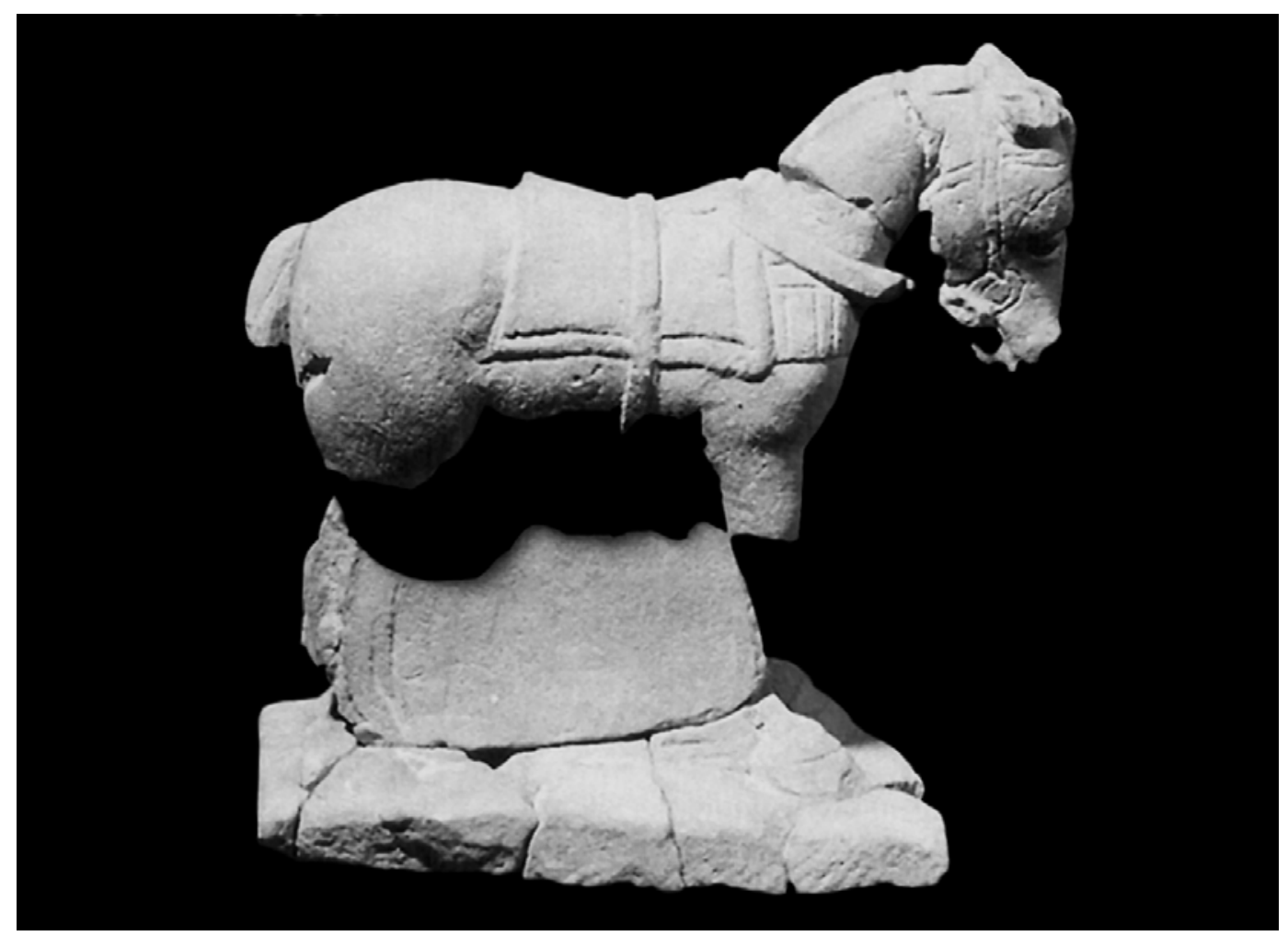

Fig. 41. Exvoto ibérico en piedra con ephippion procedente del santuario ibérico de El Cigarralejo.

En todo caso, e independientemente de su origen último, el empleo de los estribos era conocido en el s. V d.C. por diversos pueblos montados asiáticos, y se extendió desde los Avaros - pueblo emparentado con los hunos- (Fig. 40, 42) a Persia quizá en el s. VI d.C. (Nicolle, 1996:38; Azzaroli, 1985:93 relieve de Kusrav II, 591-628 d.C.; 159; Hyland 1994:11), desde donde se transmitieron rápidamente al imperio bizantino y Europa Occidental (De Vries 1992:100; Junkelmann, 1992:101), aunque entre algunos pueblos como los árabes musulmanes fueron inicialmente considerados afeminados (Nicolle, 1996:38), al igual que entre los germanos se habían considerado afeminadas las sillas de montar siglos antes.

21 Relieves en templos de los ss. II-I a.C. en Sanchi, Mathura, Pathaore y Bhaja (Azzaroli 1985:157). Pero según Azzaroli estas lazadas para el dedo gordo del pie no tuvieron descendencia, y el estribo verdadero no aparecería en la India hasta el s. X d.C. Sería pues un callejón evolutivo sin salida. Algunos autores creen que las lazadas tenían como función principal ayudar a montar, pero que no actuaban como un verdadero estribo (Clutton-Brock, 1992:76). El primer ejemplo de estribo para todo el pie es un camafeo centroasiático fechado en torno al 100 d.C. (Azzaroli 1985:158, Fig. 94).

22 En concreto, la mención del estribo en escritos militares chinos se fecha en el 477 d.C., en la biografía de un jefe militar donde se indica que el estribo procedía de las tribus nómadas de Asia Central (Azzaroli, 1985:159). Desde el 500 d.C. las representaciones de estribos son frecuentes en el arte chino. 


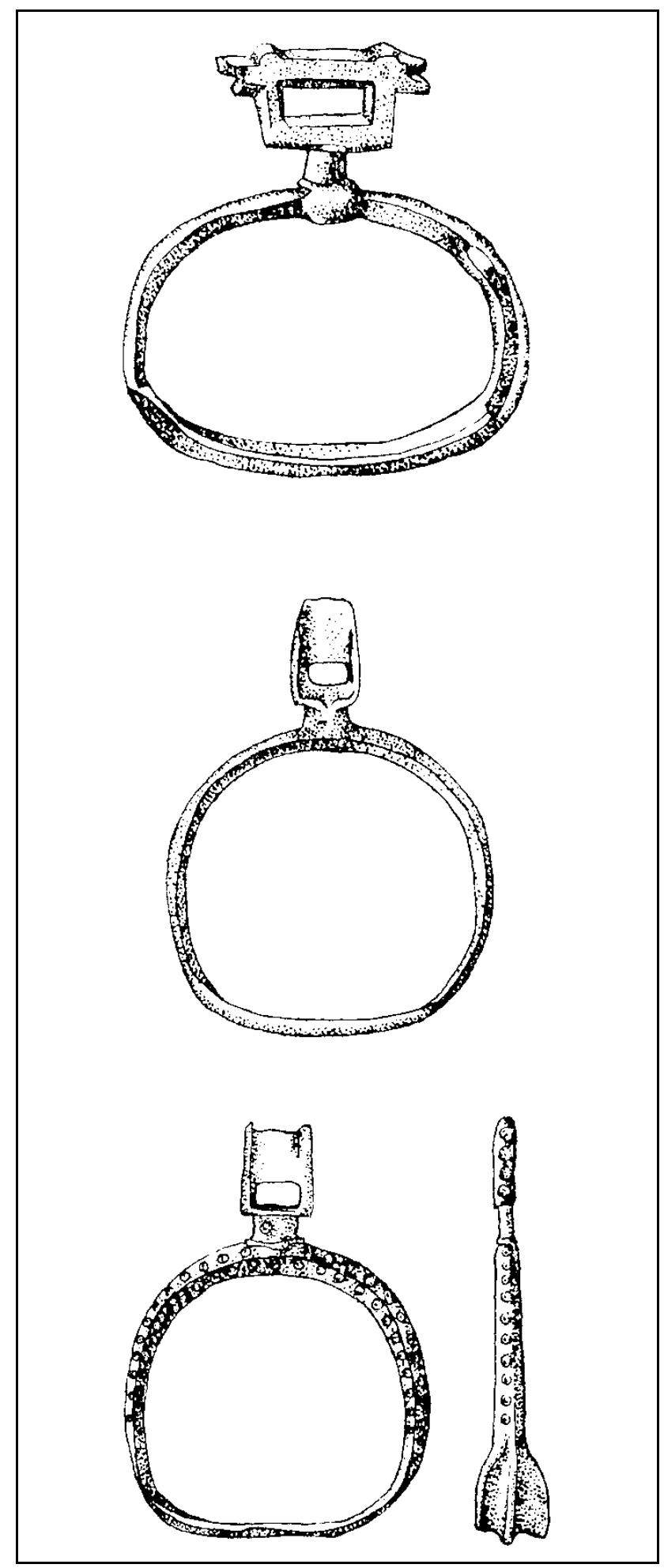

Fig. 42. Estribos primitivos: arriba, longobardo, ss. VI-VII d.C. Centro y abajo, Avaros, ss. VVI d.C. (según Azzaroli 1985). 
Los primeros estribos Avaros (Fig. 42) eran circulares aplanados en la parte inferior para sujetar mejor el pie, y contaban con una lengüeta perforada en la parte superior por la que pasaría la correa de suspensión (Stephenson, Dixon, 2003:110; Quesada, 2004). A partir de este modelo simple surgieron miríadas de variantes que concluyen en los modelos modernos.

Los datos son esquivos para Europa occidental entre el s. VII y fines del VIII d.C. A partir del s. IX aparecen ya abundantes representaciones de estribos en Europa Occidental, siendo una de las más tempranas la escena del Apocalipsis en un Beato fechado en torno al 776 d.C. La monta 'a la brida' que tan claramente se refleja en la iconografía altomedieval (por ejemplo en el tapiz de Bayeux que conmemora la Batalla de Hastings en 1066), en la que el jinete montaba encajado en una silla rígida y con las piernas estiradas, dependía tanto de la silla como del estribo en el momento del choque. De hecho, el jinete iba en pie sobre los estribos más que sentado en la silla (Fig. 43).

El estribo sin duda proporcionó ventajas al jinete: facilita la monta y la estabilidad lateral, y desde luego hace más fácil golpear bien con espada, maza o cargar con lanza pesada sujeta entre el costado y el antebrazo (Gaebel, 2002:11). Sin embargo, la Antigüedad Clásica contó con caballería capaz de cargar con lanza larga sin necesidad de estribos (Gaebel 2002:1, 911; Azzaroli, 1985 passim): su importancia, pues, ha sido a veces sobrevalorada. Todavía hoy, como en el s. XVIII, se enseña a montar sin estribos para mejor 'sentir' el caballo y ganar confianza (Junkelmann, 1992:111). Y es posible perder un estribo a galope largo por rotura de una correa y continuar montando. Aunque no cabe duda de que los estribos mejoraron la efectividad de la caballería pesada, no tuvieron un papel militar decisivo (Spence 1993:43 ss.). A veces se ha citado un pasaje de la Anábasis de Jenofonte $(3,2,19)$ en la que el griego contrapone la seguridad de los infantes con la inherente inestabilidad de los jinetes «porque ellos están suspendidos sobre los caballos y tienen miedo no sólo de nosotros, sino también de caer. Mientras que nosotros, afianzados en tierra...». Aparte de que esto suena como psicología de batalla para contrarrestar el efecto moral de la caballería enemiga (Spence 1992:43), el propio Jenofonte sostiene que es perfectamente posible asestar potentes golpes de sable desde un ephippion sin silla ni estribos (De la Equitación, 12, 12), y el episodio de Gránico en que Clito el Negro cortó amputó de un tajo en el hombro el brazo de un persa (Arriano, Anábasis 1,15,8) lo confirma, pese a la antigua opinión en contrario de autores como Adcock (1967:50) o Anderson (1961:76). En particular la falsa analogía de que montar un caballo sin estribos es como tratar de remar sin apoyo en los pies ha causado bastante confusión. Como indica Spence (1992:45), los griegos - y luego los celtas y romanos - desarrollaron prácticas que, aunque quizá no tan eficaces como el estribo, aliviaron los problemas de la monta.

Los trabajos de M. Junkelmann (1992:100 ss.) han planteado la cuestión en sus términos prácticos: dos jinetes cargando uno contra el otro se aproximarán a la aterradora velocidad, al final de la carga, de $90 \mathrm{Km} / \mathrm{h}$ (1992:103). En esas condiciones la cuestión no es conseguir potencia suficiente en el golpe, sino controlarla para tener una oportunidad de mantenerse en la silla, y con el arma controlada en la mano, tras el choque. La forma de sujetar la lanza tiene mucho que ver con el resultado: el golpe por alto o bajo, usando la fuerza del hombro y la espalda tieen más posibilidades de reutilizar el arma tras el primer choque que la lanza couchée al estilo medieval. Junkelmann concluye, tras experiencias prácticas, que en efecto es la silla con arzón y borrenes el elemento decisivo en el choque, y no el estribo, que no supuso ningún cambio decisivo en unas tácticas de choque de caballería que ya existían siglos antes. Por lo que se refiere a la otra utilidad del estribo, la monta, Junkelmann concluye que en efecto montar sin estribo plantea ciertos problemas, y que aunque es fácil montar en un caballo de pequeña alzada apoyándose en la lanza, otros elementos como el escudo debían ser entregados al jinete cuando éste ya estaba montado (1992:105 ss.)

De hecho, la cuestión de la introducción del estribo en Europa Occidental entre los siglos VII-VIII causó en su momento una gran controversia entre quienes, como L. White (1962), 
consideraban que la introducción de los estribos por la caballería franca hacia el s. VII-VIII d.C., que habría hecho de estos jinetes un elemento social dominante en una época de constantes guerras, había sido elemento fundamental en la aparición del feudalismo. El argumento se basaba en que el estribo habría causado una revolución en la guerra, permitiendo la supremacía absoluta de una caballería pesada fuertemente protegida y armada; estos jinetes requerían tiempo y recursos para una dedicación absoluta al entrenamiento militar, lo que habría llevado al nacimiento del feudalismo. Sin embargo, la opinión general hoy (CluttonBrock, 1992:76; DeVries 1992:95 ss.; Junkelmann, 1992:102ss; Contamine, 1984:230-235) es que ésta era una postura mecanicista y unifactorial insostenible, ya que ni el estribo supuso una verdadera revolución tecnológica en las décadas oscuras que siguieron a la época de las invasiones, ni la caballería cambió, ni alteró la realidad del campo de batalla, en términos de 'revolución militar'. Además, si bien el estribo se generalizó en Francia hacia el s. VIII d.C., todavía en el s. XI d.C. se empleaba a menudo la lanza pesada al modo antiguo, es decir de estoque, usando la fuerza del brazo y el hombro para golpear, y no trabando la lanza entre costado y brazo para lanzar una carga irresistible en la que el impacto llevaba el peso combinado de jinete y montura. En consecuencia, estribo y 'lance couchée' sujeta entre torso y brazo, bajo la axila, no parecen haber sido innovaciones simultáneas.

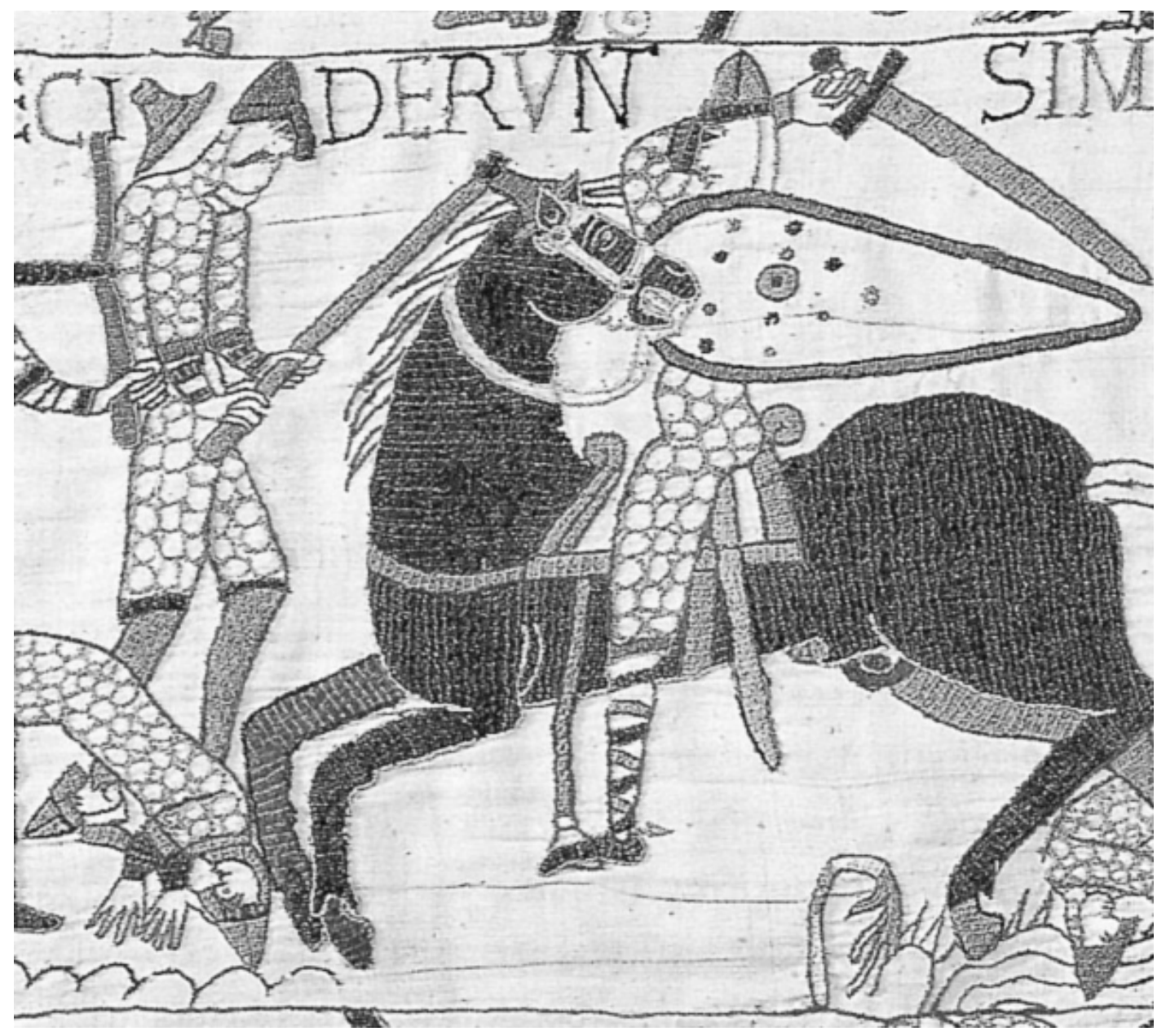

Fig. 43. Jinete normando del s. XI montando 'a la brida' con estribo. Del Tapiz de Bayeux. 


\section{LA CUESTIÓN DE LA HERRADURA EN LA ANTIGÜEDAD}

Dedicaremos por fin unas líneas a una cuestión controvertida y, a la postre, todavía irresuelta: la de las herraduras. En síntesis, las excavaciones del Marqués de Cerralbo plantearon a principios del s.XX que en el mundo celtibérico prerromano se habría empleado la herradura clavada, y no la hiposandalia (sobre esta última, ver entre abundantes referencias Vigneron 1968:44 ss.; Lawson 1978:133 ss.; Alvarez Rico 2003:167 ss.), a partir de diversos hallazgos en necrópolis celtibéricas como Aguilar de Anguita y Luzón (Aguilera y Gamboa, 1916:43 ss.; Alvarez Rico 2003:162 ss. y Lám. II) y en particular de una herradura aparentemente mezclada con otras armas en la necrópolis de La Requijada de Gormaz excavada por Morenas de Tejada (Aguilera y Gamboa 1916:Apéndice II). A estos datos se unieron otros posteriores, como la espuela hallada en el yacimiento ibérico de Covalta (Valencia) sin contexto preciso (Alvarez Rico 2003:Lám. 3.1) y otra en el entorno del campamento romano de época sertoriana de Cáceres el Viejo (Alvarez Rico 2003:156, 165).

Puesto que la hipótesis tradicional era que el mundo clásico sólo conoció la hiposandalia como forma de proteger los delicados cascos de los caballos, y que el empleo de la herradura se documenta sólo con seguridad a partir del s. IX d.C., incluso posterior a los estribos, este descubrimiento, junto con otros parecidos dispersos por toda Europa, levantó cierta polémica que se ve renovada de cuando en cuando por nuevos hallazgos sin que hasta ahora haya alcanzado solución satisfactoria. ${ }^{23}$

Para resumir la cuestión nos limitaremos a resumir algunas de las conclusiones del importante trabajo de Mauricio Alvarez Rico (2003) quien, bajo nuestra supervisión, ha realizado el intento más reciente y completo de examinar el conjunto de la evidencia en Europa sin alcanzar, hay que decirlo desde el principio, conclusiones definitivas.

Básicamente, quienes se oponen a la existencia de herraduras desde al menos el s. IV a.C: enfatizan el hecho de que nunca se hayan encontrado éstas en contextos de excavación controlada plenamente fiables donde no haya peligro de contaminación desde estratos superiores tardíos de estos objetos pesados y densos. Más débil es la argumentación de falta de herraduras en tumbas de guerreros: no es un objeto de ajuar sino una protección de la montura que en principio no tendría cabida entre ofrendas funerarias (y pese a ello contamos con el caso fotografiado de Gormaz). Por otra parte, la rica iconografía romana no presenta ningún caso indudable de herraduras y sí muchos de hiposandalias; algún caso que se ha argumentado parece corresponder a restauraciones renacentistas. En cambio, las primeras herraduras datadas con seguridad, en el s. IX d.C., coinciden con las primeras representaciones claras en el arte y citas en fuentes literarias.

Frente a ello, los defensores de la existencia de herraduras antiguas argumentan algunos casos fiables (e.g. Venizy, Linz, Virunum, Bessancourt, etc), y también al menos un caso en el que una herradura formaba parte del ajuares de una sepultura (La Requijada); el número de herraduras halladas en contextos antiguos es ya excesivo para explicarse sólo en términos de intrusiones. Para estos autores, la falta de hallazgos de herraduras ha podido deberse al predominio de la teoría del origen medieval, que llevaría a muchos a no tener en cuenta descubrimientos reales, o a acallarlos para no sembrar dudas sobre la fiabilidad de la datación de los yacimientos que excavan. Por otra parte, se argumenta que incluso si la herradura no se empleó en Roma, ello no impide desarrollos locales en zonas periféricas. La argumentación de que la herradura pudo no formar parte del equipamiento militar, empleándose sólo para

23 «En el campo arqueológico hemos de partir de las primeras herraduras cuya datación es segura, procedentes del lago Paladrú (Francia) y fechadas en torno al siglo X d.C. De esta misma zona proceden las primeras menciones escritas conocidas, fechadas desde un poco antes: mediados del siglo VII, también en el siglo IX y, nuevamente, en el siglo X. En Oriente el primer ejemplo es del siglo IX-X d.C. En la iconografia las representaciones seguras de herraduras comienzan a ser abundantes a partir de este mismo siglo X» (Alvarez Rico 2003:167 y passim) 
animales de carga, entra en contradicción por otra parte con el caso de Requijada, y en todo caso no parece aceptable: las ventajas de la herradura son tales que sin duda se hubiera adaptado a las unidades de caballería. Estos autores también presentan algunas representaciones que supuestamente incluyen caballos herrados, como el cofre de Carnuntum, el relieve de Lauricum, una tesera de Domiciano, y sarcófagos como uno de Camposanto (Pisa) y otro en el Vaticano.

Como resultado de lo expuesto por Álvarez Rico en sumo detalle, y sintetizado en el párrafo anterior, «sólo cabe decir que los datos fiables con los que podríamos contar para avalar alguna de las dos tesis resultan demasiado escasos. El siglo, ya largo, de discusiones no ha permitido verter más luz sobre el problema, en parte por las circunstancias propias de la materia misma en estudio y, en parte, por lo apasionado de estas discusiones» (Âlvarez Rico 2003:167). Las limitaciones en la evolución tipológica de la herradura y la imposibilidad de fecharlas de modo independiente hacen muy difícil su investigación.

FERNANDO QUESADA SANZ

Dpto. de Prehistoria y Arqueología. Facultad de Filosofia y Letras. Universidad Autónoma de Madrid

E-mail: fernando.quesada@uam.es

\section{BIBLIOGRAFIA}

Abascal Palazon, J.M.; Sanz Gamo, R. (1993): Bronces Antiguos del Museo de Albacete. Albacete.

ADCOCK, F.E. (1967): The Greek and Macedonian Art of War.

Aguilera y Gamboa, E. (1911, inédito): Páginas de la Historia Patria por mis excavaciones arqueológicas. Manuscrito inédito. Premio Martorell.

Aguilera y Gamboa, E. (1916): Las necrópolis ibéricas. Edición aparte del tomo II de la Asociación Española para el Progreso de las Ciencias. Madrid.

ALDANA NaCher, C. (1984): «Un nuevo exvoto ibérico procedente del cerro de San Miguel de Liria (Valencia)». Archivo de Arte Levantino 65, pp. 82-83.

Almagro Gorbea, M. (1996): Ideología y poder en Tartessos y el mundo ibérico. Madrid.

Alvarez Gracia, A. et alii (1990): «Elementos metálicos de tipo celtibérico: la colección Pérez Aguilar». F. Burillo (ed.) Necrópolis Celtibéricas. II simposio sobre los Celtíberos. Zaragoza, pp. 287-304.

Alvarez Rico, M. (2003): «La cuestión de la herradura en la Antigüedad». En F. Quesada, M. Zamora (Eds.) El caballo en la antigua Iberia. Madrid: 145-178.

ANDERSON, J.K. (1961): Ancient Greek Horsemanship. Berkeley.

AQuiLuE, X. et alii (1999): Intervencions arqueològiques a Sant Martí d'Empúries (1994-1996) De l'assentament precolonial a l'Empuries actual. Monografies Emporitanes 9. Girona.

Argantonio (2000): Argantonio. Rey de Tartessos. Sevilla.

Argente Oliver, J.L.; Diaz, A.; Bescos; A. (2000): Tiermes V. Carratiermes necrópolis celtibérica. Campañas 1977 y 1986-1991. Memorias. Arqueología en Castilla y León, 9. Valladolid.

ARTiÑANO Y GALDÁCANO, P.M. de (1919): Exposición de hierros antiguos españoles. Madrid.

AZZAROLI, A. (1985): An Early History of Horsemanship. Leiden.

BALKWILL, C.J. (1973): «The earliest horse-bits of Western Europe» Proceedings of the Prehistoric Society 39, pp. 425-452. 
Ballester, I. et alii, 1954: Cerámica del Cerro de San Miguel. Liria. Corpvs Vasorum Hispanorum. Madrid.

BAQUEDANO BELTRAN, I. (1990): «Elementos relacionados con el caballo en tumbas inéditas de La Osera». II Simposio sobre Celtíberos. Necrópolis Celtibéricas, pp. 279-286. Zaragoza.

BAQUEDANO BELTRAN, I. (2002): «Doña Encarnación Cabré Herreros y la investigación arqueológica. Algunas notas sobre sus aportaciones científicas a través de sus publicaciones».E. García-Soto y M.A: García (Eds.) I Simposio de Arqueología de Guadalajara. Homenaje a Encarnación Cabre Herreros.I-II. Guadalajara, pp. 21-29.

BArril ViCEnTE, M. (1993): «Colección Marqués de Cerralbo». En De Gabinete a Museo. Tres siglos de Historia. Museo Arqueológico Nacional. Madrid, pp. 406-413. Badajoz.

BerRocal RANGel, L. (1998): La Baeturia. Un territorio prerromano en la Baja Extremadura.

Bishop, M.C.; COUlston, J. (1993): Roman Military Equipment. London.

Blech, M. (2003): «Elementos de atalaje de Cancho Roano». En S. Celestino (ed.) Cancho Roano VIII. Los materiales arqueológicos II. Mérida, pp.159-192.

BockIUS, R., 1991: «Zu den elbgermanischen kreisplattensporen der frühen Römischen Kaiserzeit». Jahrbuch RGZM 38.2, p. 497-514.

BRITTON, V. (1995): The complete tack guide. Ramsbury.

BRITTON, V (1997): El equipo del caballo. Ripollet.

BUDIANSKY, S. (1997): The nature of Horses. Their evolution, intelligence and behaviour. London.

BURANELLI, F, (1997): «Le applicazioni metalliche; maestranze e botteghe (carro di Roma Vecchia)». A. Emilozzi (coord.) Carri da guerra e principi etruschi, pp. 202. Roma.

Cabre Aguilo, J. (1930): Excavaciones en la necrópoli celtibérica de Altillo de Cerropozo. Atienza (Guadalajara). MJSEA 105. Madrid.

Cabre Aguilo, J. (1932): Excavaciones de Las Cogotas, Cardeñosa (Avila). II. La necrópoli. MJSEA 120. Madrid.

Cabré Aguilo, J.; Cabre De Moran, E.; Molinero, A. (1950): El castro y la necrópolis del Hierro Céltico de Chamartín de la Sierra (Avila). Actga Arqueológica Hispanica V. Madrid.

CABRÉ DE MORAN, M.E. (1990): «Espadas y puñales de las necrópolis celtibéricas». F. Burillo (ed.) Necrópolis Celtibéricas. II simposio sobre los Celtíberos. Zaragoza, pp. 205-224.

Celestino Perez, S. (2001): Cancho Roano. Madrid.

Celestino Perez, S. (2001b): «Los santuarios de Cancho Roano. Del indigenismo al Orientalismo Arquitectónico». D. Ruiz Mata, S. Celestino (eds.) Arquitectura Oriental y Orientalizante en la Península Ibérica, pp.17-56. Madrid.

Celestino Perez, S.; Julian Rodriguez, J.M. (1991): «El caballo de bronce de Cancho Roano». CUPAUAM 18, 179-188.

Clutton-Brock, J. (1992): Horse power. A history of the horse and the donkey in human societies. London.

ColonnA, G. (1997):: «L'Italia Antica: italia centrale». A. Emilozzi (coord.) Carri da guerra e principi etruschi, pp. 15-23. Roma.

ConNOlly, P. (1981): Greece and Rome at War. London.

Connolly, P. (1986): «A Reconstrucion of a Roman Saddle». Britannia 17, pp. 353-355.

CONNOLLY, P. (1989): Las legiones romanas. Madrid.

CONNOLly, P.; VAN DRIEL-MURRAY, C. (1991): «The Roman cavalry saddle». Britannia 22, 33-50.

Contamine, P. (1984): La guerra en la Edad Media. Barcelona. 
Crouwel, J. (2002, ed. or. 1987): «Chariots in Iron Age Cyprus».P. Raulwing (ed.) Selected writings on chariots, other early vehicles, Riding and harness by M.A. Littauer and J. Crouwel. Leiden, Brill, pp.141-173.

CUADRADO, E. (1948): «Arreos de montar, ibéricos, de los ex-votos del santuario del Cigarralejo». IV Congreso Arqueológico del Sureste Español. Cartagena, pp. 267-287.

CuAdrado, E. (1950): Excavaciones en el Santuario Ibérico del Cigarralejo (Mula, Murcia). Informes y Memorias 21. Madrid.

Cuadrado, E. (1979): «Espuelas ibéricas». XV Congreso Nacional de Arqueología, Lugo 1977. Zaragoza 1979, 735-740.

CuAdrado, E., (1987): La necrópolis ibérica de El Cigarralejo (Mula, Murcia). Bibliotheca Praehistorica Hispana XXIII. Madrid.

Cygielman, M. (1997): «La tomba del Littore di Vetulonia ed i suoi carri». A. Emilozzi (coord.) Carri da guerra e principi etruschi, pp.263-273. Roma.

DE VRIES, K. (1992): Medieval Military Technology. Plymouth/New York.

Dechelette, J. (1927): Manuel d'Archéologie Préhistorique et Celtique. 4. Second âge du Fer. Epoque de La Tène. Paris.

DENNIS, G.T. (Transl. and Ed.) (2001): Maurice's Strategikon. A Handbook of Byzantine Strategy. Univ. of Pennsylvania Press.

Dixon, K.R.; Southern, P. (1992): The Roman Cavalry. From the First to the Third Century $A D$. London.

Donder, H. (1980): Zaumzeug in Griechenland und Cypern. Prähistorische Bronzefunde XVI.3 München.

EDWARDS, E.H. (1994): El bocado: teoría y práctica. Avila.

EMILIOZZI, A. (1997): Carri de guerra e principi etrusci. Roma.

EMiliozZI, A. (1997b): «Il carro di Roma dalla tenuta di Roma Vecchia sull'Appia Antica». A. Emilozzi (coord.) Carri da guerra e principi etruschi, pp. 191-202. Roma.

FERnANDEZ GómeZ, F. (1997): La necrópolis de la Edad del Hierro de 'El Raso' (Candeleda, Avila). «Las Guijas, B». Memorias de Arqueología en Castilla y León, 4. Zamora.

FERNANDEZ JURADO, J. et alii (1988-89): Tartessos y Huelva. Huelva Arqueologica, 10-11.

Ferrer Albelda, E.; Mancebo Davalos, J. (1991): «Nuevos elementos de carros orientalizantes en la Alta Andalucía. Algunas precisiones en torno a su fucnión, significado y distribución». $\mathrm{Cu}$ PAUAM 18, 113-148.

FEUGere, M. (1993): Les armes des Romains de la République à l'Antiquité tardive. Paris.

GAEBEL, R.E. (2002): Cavalry operations in the Ancient Greek World. Univ. Oklahoma

Garces Estallo, I. (2002): «Morrió de cavall». Sala d'Arqueología. Catàleg. Lleida, pp. 198-199.

Garcia CANO, J.M., 1997: Las necrópolis ibéricas de Coimbra del Barranco Ancho (Jumilla, Murcia). I. Las excavaciones y estudio analítico de los materiales. Murcia.

GARCIA CANO, J.M. et alii (1997): «El santuario de Coimbra del Barranco Ancho (Jumilla, Murcia) a la luz de los nuevos hallazgos». Quaderns de Prehistòria i Arqueología de Castelló 18, 239-256.

GARCÍA-SOTO MATEOS, E. (2002): «Algunas razones para un merecido homenaje». E. GarcíaSoto y M.A: García (Eds.) I Simposio de Arqueología de Guadalajara. Homenaje a Encarnación Cabre Herreros.I-II. Guadalajara, pp. 19-20.

GARRIDO, J.P.; ORTA, E. (1978): La necrópolis de la Joya (Huelva) II. Excavaciones arqueológicas en España 96. Madrid.

GOLDSWORTHY, A. (2003): The complete Roman Army. London.

GOMES, M. VARELA (2001): «Divinidades e santuarios púnicos, ou de influencia púnica, no sul de Portugal». Os púnicos no extremo occidente. Actas del coloquio de Lisboa 2000. Lisboa, pp. 99 ss. 
GonZALEZ ReYero, S. (2002-03): «Nueva aproximación a los estudios ibéricos de principios de siglo. Juan Cabré y la fotografía». Homenaje a la Dra. Dña. Encarnación Ruano. Boletín de la Asociación Española de Amigos de la Arqueología 42, pp. 265-292.

GraciA, F.; MuniLla, G. (1993): «Estructura cronocupacional del poblamiento ibérico en las comarcas del Ebro». Laietania 8, pp. 209-255.

Gracia, F.; Munilla, G.; GARCIA, D. (2000): «Moleta del Remei (Alcanar, Montsià). Balance de la investigación 1985-1997». En R. Buxó, E. Pons (eds.) L’hàbitat protohistòric a Catalunya, Rosselló I Llenguadoc Occidental. Actualitat de l'Arqueología de l'Edat del Ferro. Actes del XXII Col.loqui Internacional per a l'Estudi de l'Edat del Ferro. Girona. Serie Monografica del Mac-Girona,19. Girona, pp. 59-71.

Hase, F.W. von (1969): Die Trensen der Früheisenzeit in Italien. Prähistorische Bronzefunde XVI.1. München.

HERRMANN, H.V. (1968): «Frügriechischer Pferdeschmuck vom Luristantypus. Jahrbuch des Deutsches Arcäologisches Institut 63, 1-38.

Hyland, A. (1990): Equus. The Horse in the Roman World. London.

Hyland, A. (1993): Training the Roman Cavalry from Arrian s Ars Tactica. Stroud.

HYland, A. (1994): The Medieval Warhorse. From Byzantium to the Crusades. Stroud.

HyLAND, A. (2003): The horse in the Ancient World. Stroud.

IZQUIERDO, I. (2000): Monumentos funerarios ibéricos: los pilares-estela. SIP Trabajos Varios 98, Valencia.

JAHN, M. (1921): Der Reitersporn. Seine Entstehung und früheste Entwicklung. Mannus-Bibl. 21. Leipzig.

JimÉnez AviLA, J. (2002): La toreútica orientalizante en la Península Ibérica. Bibliotheca Archaeologica Hispana 16. Madrid.

Jimenez Avila, J.; MuÑoz Lopez-Astilleros, K. (1997): «Pasarriendas de bronce en la Protohistoria peninsular: a propósito del hallazgo del Soto del Hinojar-Las Esperillas (Aranjuez, Madrid)». CUPAUAM 24, 119-158.

Junkelmann, M. (1992): Die Reiter Roms. Teil III: Zubehör, Reitweise, Bewaffnung. Mainz.

KurTz, W.S. (1986-87): «Los arreos de caballo en la necrópolis de Las Cogotas (Avila)». Coloquio Internacional La Edad del Hierro en la Meseta Norte, Zephyrus 39-40, pp. 459-473.

LAWSON, A.K. (1978): «Studien zum Römischen Pferdegeschirr», Jahrbuch des Römisch-Germanischen Zentralmuseums Mainz, 25, pp. 131-172.

LefEBVRE Des NoËtTeS, C. (1931): L'Attelage. Le cheval de selle à travers les âges, París.

LEVINE, M. (2004): «Exploring the criteria for Early Horse domestication». En M. Jones (ed.) Traces of Ancestry: studies in honour of Colin Renfrew. Mc. Donald Institute Monographs. Oxford, pp. 115-126.

LitTAuer, M.A.; Crouwel, J. (1979): Wheeled vehicles and ridden animals in the Ancient Near East. Leiden, Brill.

LUCAS PELLICER, M.R. (2004): «Narigón y ronzal vs. Bocado de caballo: el arrastre de los équidos». Gladius 24, pp. 99-108.

MALUQuer De Motes, J. (1981): «El santuario protohistórico de Zalamea de la Serena, Badajoz. 1978-1981». Andalucía y Extremadura I, Programa de Investigaciones Protohistóricas IV. Barcelona.

MALUQuer De Motes, J. (1983): «El santuario protohistórico de Zalamea de la Serena, Badajoz. II., 1981-1982». Andalucía y Extremadura II, Programa de Investigaciones Protohistóricas V. Barcelona (1987).

Maluquer de Motes, J. (1987): El poblado paleoibérico de Lña Ferradura, Ulldecona (Tarragona). PIP VII. Barcelona. 
Mangani, E.; EMILIOZZI, A. (1997): «Capena, necropoli di San Martino. Il carro dalla Tomba XVI». A. Emilozzi (coord.) Carri da guerra e principi etruschi, pp. 285-290. Roma.

Marin CEBAllos, M.C.; PAdilla, A. (1997): «Los relieves del 'domador de caballos' y su significación en el contexto religioso ibérico». Quaderns de Prehistòria i Arqueología de Castelló 18, 461-494.

MENARD, AD.A.J. (2001): Traduction et commentaire de fragments des hippiatrica (Apsyrtos, Theomnestos). These Ecole Nationale Veterinaire d'Alfort. Ver la dirección Web http://www.bium. univ-paris5.fr/histmed/asclepiades/ dmenard.htm (consultada 10 Mayo 2004).

Mesado Oliver, N. (2003): «El caballo ibérico de La Regenta (Burriana, Castellón». En F. Quesada, M. Zamora (eds.) El caballo en la Antigua Iberia. Bibliotheca Archaeologica Hispana 19. Madrid, pp.179-186.

Morenas de TeJadas (1916): «Las ruinas de Uxama», Por esos Mundos, octubre, pp. 605-610.

NiCOLLE, D. (1996): Medieval Warfare Source Book. Christian Europe and its neighbours. London.

Perez Minguez, R. (1992): «Acicates ibéricos del Museo de Prehistoria de Valencia». Homenaje a Enrique Pla Ballester. SIP Trabajos Varios, 89. Valencia, p. 215-220.

PiggotT, S. (1992): Wagon, Chariot and Carriage. Symbol and Status in the History of Transport. London.

QueSADA SANZ, F. (1997): El armamento ibérico. Estudio tipológico, geográfico, funcional, social y simbólico de las armas en la Cultura Ibérica (siglos VI-I a.C.). I-II. Monographies Instrumentum 3. Montagnac.

QueSADA SANZ, F. (1998a): «From quality to quantity:wealth, status and prestige in the Iberian Iron Age». D. Bailey (ed.) The Archaeology of Value, BAR IS 730, pp. 70-96. Oxford.

QUESADA SANZ, F. (1998b): «Aristócratas a caballo y la existencia de una verdadera 'caballería' en la cultura ibérica: dos ámbitos conceptuales diferentes». En C. Aranegui (ed.) Los Iberos, príncipes de Occidente. Actas del Congreso Internacional. Barcelona, pp.169-183.

QUESADA SANZ, F. (2001-2002): «En torno a las espuelas articuladas ibéricas, artesanado y las relaciones entre las regiones murciana y granadina». Studia E. Cuadrado, An. Murcia 16-17, 20012002, pp. 239-246.

QUESADA SANZ, F. (2002-2003): «Un elemento de bocado de caballo de tradición Orientalizante en el Museo Arqueológico de Murcia». Homenaje a E. Ruano, BAEAA 42, 2002-2003, pp. 231-242.

QUESADA SANZ, F. (2002-2003b): «Mirando el mundo desde lo alto: espuelas y otros elmentos asociados al caballo en el poblado de La Serreta de Alcoi». Recerques del Museu d'Alcoi 11-12, 85-100.

QuESADA SANZ, F. (2004): «Juan Cabré y los estudios de cultura material ibérica y celtibérica ayer y hoy. Los arreos de caballo como estudio de caso». En J. Blánquez, B. Rodríguez (eds.) El arqueólogo Juan Cabré (1882-1947). La fotografia como técnica documental. Madrid, pp.250-261.

QueSADA SANZ, F. (2004b): «La silla de montar» La Aventura de la Historia 62, 106-107.

QuesADA SANZ, F. (2005): «Patterns of interaction: 'Celtic' and 'Iberian' weapons in Iron Age Spain». Celtic Connections, vol. II. Papers from the Tenth International Congress of Celtic Studies, Edinburg 1995, pp. 56-78.

Quesada SAnz, F.; Martinez Rodriguez, A., (1995): «Un lote de armas procedente del yacimiento de Carranza (Huéscar de Granada) y la cuestión de las vías de comunicación entre Granada y Murcia». Verdolay 7, p. 239-250.

Quesada SAnZ, F.; TORTAJADA, M. (1999): «Caballos en arcilla de la Segunda Edad del Hierro en la Península Ibérica». CUPAUAM 25.2, pp. 9-53.

QuesadA SANZ, F.; ZAMORA MERCHAN, M. (eds.) (2003): El caballo en la antigua Iberia. Estudios sobre los équidos de la Edad del Hierro. Bibliotheca Archaeologica Hispana 19. Madrid.

QUESADA SANZ, F. et alii (2000): «¿Artesanos itinierantes en el mundo ibérico?, Sobre técnicas y estilos decorativos, especialistas y territorio». Saguntum Extra 3, pp. 291-301.

SANDARS, H. (1913): The Weapons of the Iberians. Oxford. 
SANZ MingueZ, C. (1997): Los Vacceos: cultura y rtitos funerarios de un pueblo prerromano del valle medio del Duero. La necrópolis de Las Ruedas Padilla de Duero (Valladolid). Memorias de Arqueología en Castilla y León, 6. Salamanca.

SCHÜLE, W. (1969): Die Meseta-Kulturen der Iberischen Halbinsel. I-II. Berlin.

SCHULTEN, A. (1927): Numantia III. München.

SCHWINDEN, L. (1987): «Zur Trageweise der Metallhackamore bei römischen Pferden». Funde und Ausgrabungen im Bezirk Trier, 19, 36-41.

SHORTT, H. de S., (1959): «A provincial Roman spur from Longstock, Hants., and other spurs from Roman Britain». The Antiquaries Journal 39, p. 61-76.

SPENCE, I.G. (1993): The cavalry of Classical Greece. A social and military history. Oxford. Berlín.

STARY, P.F. (1994): Zur Eisenzeitlichen Bewaffnung Kampfesweise auf der Iberischen Halbinsel,

StePHENSON, I.P.; DiXON, K.R. (2003): Roman Cavalry Equipment. Stroud.

SUMMERHAYS, R.H. (1993, ed. or. 1988): Encyclopaedia for Horsemen. London.

TAYLOR, A.K. (1975): «Römische hackamoren und Kappzäume aus metall». Jahrbuch RGZM 22, pp. 106-133.

Ulbert, G. (1984): Cáceres el Viejo. Ein spätrepublikanisches Legionsläger in SpanischExtremadura. Madrider Beiträge 11. Mainz am Rheim.

Vigneron, P., (1968): Le cheval dans l'antiquité gréco-romaine. Nancy.

WERNER, W.M. (1988): Eisenzeitliche Trensen an der unteren und mittleren Donau. Prähistorische Bronzefunde XVI.4. München.

White, L. (1962): Medieval Technology and Social change. Oxford 